\title{
RETHINKING SEX AND THE CONSTITUTION
}

\author{
Sylvia A. LAW ${ }^{\dagger}$
}

\section{INTRODUCTION}

This Article attempts to articulate a stronger constitutional concept of sex-based equality than that which currently exists. ${ }^{1}$ The central thesis is that the development of modern constitutional sex equality doctrine has suffered from a lack of focus on biological reproductive differences between men and women. The reality of sex-based physical differences poses a significant problem for a society committed to ideals of individual human freedom and equality of opportunity.

To the extent that constitutional doctrine shapes culture and individual identity, an equality doctrine that denies the reality of biological difference in relation to reproduction reflects an idea about personhood that is inconsistent with people's actual experience of themselves and the world. The constitutional ideal alienates people from their own experience. Given our history in which the idea of "man" is the linguistic and legal equivalent of "person," a concept of equality that denies biological difference has particularly adverse effects upon women.

The central biological difference between men and women is that only women have the capacity to create a human being. For many people, the decision to bear a child is jointly made by a man and a woman and is the occasion for joyous commitment to one another, to the child, and to the future. But it is not always so. Only women can grow a human being, and, although sperm is also needed, it is easily obtainable. $^{2}$ The power to create people is awesome. Men are profoundly

$\dagger$ Professor of Law, New York University. B.A. 1964, Antioch College; J.D. 1968, New York University. Many people generously provided intellectual support and enriching criticism: Janet Benshoof, Rhonda Copelon, Peggy Davis, Norman Dorsen, Ruth Bader Ginsberg, Nan Hunter, Barry Ensminger, Nancy Erickson, Martha Field, Ken Karst, Herma Hill Kay, Cynthia Kern, Jane Levine, Susan Rotgard, Norman Redlich, David Richards, Lawrence Sager, Nancy Miller, Francis Olsen, Jane Schacter, Elizabeth Schneider, Phyllis M. Segel, Stephanie Wildman, and NYU's Law and Philosophy Group.

1 For an excellent early treatment of the issues addressed here, see Karst, The Supreme Court, 1976 Term-Foreword: Equal Citizenship Under the Fourteenth Amendment, 91 HaRv. L. REv. 1, 53-59 (1977). For a recent, perceptive discussion of these issues by a principal architect of contemporary constitutional sex discrimination doctrine, see Judge Ruth Bader Ginsberg, Some Thoughts on Autonomy and Equality in Relation to Roe v. Wade, William T. Joyner Lecture, Univ. of N.C. School of Law, Apr. 6, 1984 (forthcoming in N.C.L. REv. 1984).

2 Women who choose to do so can ordinarily obtain sperm through sexual rela- 
disadvantaged by the reality that only women can produce a human being and experience the growth of a child in pregnancy. Pregnancy and childbirth are also burdensome to health, mobility, independence, and sometimes to life itself, and women are profoundly disadvantaged in that they alone bear these burdens. ${ }^{3}$ And although men may be disadvantaged by their relatively minor role in reproduction, we have constructed a society in which men are advantaged, relative to women, in important material and spiritual ways.

The focus here is exclusively on a relatively narrow point of constitutional sex equality doctrine. I do not deal comprehensively with the critical equality issues of state action and the public/private split, ${ }^{4}$ or with the question when discrimination can be proved by showing that state policy in fact has discriminatory effects, ${ }^{5}$ or with the issue of affirmative programs to redress the disabilities of past discrimination. ${ }^{6}$ Further, I make no effort to describe an affirmative program to promote greater sex-based equality. ${ }^{7}$ The judicial enforcement of constitutional norms, even when broadly conceived and applied, is not likely to produce sex-based equality. Achieving sex-based equality requires social movement for transformation of the family, child rearing arrangements, the economy, the wage labor market, and human consciousness. No constitutional principle mandates or allows courts to effectuate the range of changes needed to allow actual equality between men and women. ${ }^{8}$ Nonetheless, constitutional concepts of equality are important

tions. Sperm banks, both formal and informal, are available to women who want a child but do not want sexual relations. See, e.g., D. Hitchens, Lesbians Choosing MotherHoOd: LEgAL Issues IN DONOR INSEMINATION (1981); Annas, Artificial Insemination: Beyond the Best Interests of the Donor, 9 Hastings CENTER REP., Aug. 1979, at 14; Curie-Cohen, Luttrell \& Shapiro, Current Practice of Artificial Insemination by Donor in the United States, 300 NEw ENG. J. MED. 585, 588 (1979); Kritchevsky, The Unmarried Woman's Right to Artificial Insemination: $A$ Call for an Expanded Definition of Family, 4 HaRv. WOMEN's L.J. 1 (1981).

3 Regan, Rewriting Roe v. Wade, 77 Mich. L. Rev. 1569, 1579-83 (1979) provides an excellent summary of the physical burdens of pregnancy.

t See, e.g., Olsen, The Family and the Market: A Study of Ideology and Legal Reform, 96 HARv. L. REv. 1497 (1983).

s But see infra notes $126-80$ and accompanying text.

- But see infra notes 214-15 and accompanying text.

7 For an affirmative agenda, see, e.g., Frug, Securing Job Equality for Women: Labor Market Hostility to Working Mothers, 59 B.U.L. REv. 55 (1979); Powers, Sex Segregation and the Ambivalent Directions of Sex Discrimination Law, 1979 WIS. L. REv. 55; Scales, Towards a Feminist Jurisprudence, 56 IND. L.J. 375 (1981).

8 Women now aspire to the constitutional protection afforded blacks. Even the relatively more rigorous anti-discrimination principle applied to racial discrimination, however, has not produced equality. See, e.g., D. BELL, RACE, RACISM AND AMERICAN LAw (1980); Freeman, Legitimizing Racial Discrimination Through Antidiscrimination Law: A Critical Review of Supreme Court Doctrine, 62 MinN. L. Rev. 1049 (1978). 
both because of their concrete impact on legislative power and individual right and because constitutional ideas reflect and shape culture.

The relationship between constitutional concepts and culture is reciprocal. The rise of the women's movement in the early 1970's provided impetus for Supreme Court revision of constitutional standards applicable to laws controlling reproduction and incorporating sex-based classifications. The ideas of equality reflected both in Supreme Court decisions under the fourteenth amendment and in the recently defeated Equal Rights Amendment in turn generate more general thought about sex-based equality. Contemporary ideas of equality are also reciprocal in relation to our past in two significant ways. First, historically, biology provided a central justification for the subjugation of women. That history partially explains the lack of focus on reproductive difference in contemporary equality doctrine and also suggests the need for close attention to such differences in developing new ideas of equality. Second, "protection" of women-construction of the pedestal/cage-was a core mechanism for oppression of women. Contemporary feminists are hence rightly skeptical of measures that protect women by providing them with special treatment. ${ }^{\theta}$

At various periods the law has embodied different ideas about sexbased differences. Prior to the mid-nineteenth century, culture and religion required women to marry, and the law declared the married woman dead. ${ }^{10}$ The law denied married women both identity and power. ${ }^{11}$ With the enactment of the married women's property acts in

- On the damage that protective legislation does to women, see B. BABCock, A. Freedman, E. Norton \& S. Ross, Sex Discrimination and the Law: Causes ANd Remedies 26-53 (1973) [hereinafter cited as B. Babcock, Sex DiscriminaTION]; Taub, Book Review, 80 ColuM. L. Rev. 1686 (1980) (reviewing C. MaCKinnon, Sexual Harrassment of Working Women: a Case of Sex DiscriminaTION (1979)).

10 "By marriage, the husband and wife are one person in law: that is, the very being or legal existence of the woman is suspended during the marriage, or at least is incorporated . . . into that of the husband: under whose wing, protection and cover, she performs everything ...." $1 \mathrm{~W}$. BlaCkSTONE, CoMmentaRIES ON THE LAWS OF ENGLAND 430 (Oxford 1765) (footnote omitted).

11 This incorporation of legal existence gave the husband all the power: "[He] was regarded as her head and representative in the social state . . . " Bradwell v. State, 83 U.S. (16 Wall.) 130, 141 (1872) (Bradley, J., concurring). A married woman could not bind herself by contract; her contracts were considered void, as an infant's, not just voidable. Her husband gained control and management of her real property and complete ownership of her personal property. Her services belonged to her husband. Therefore, he had sole right to any wages she earned outside the home. His domicile became hers. She could not sue or be sued; her husband had to be joined in any legal action. If any recovery was obtained through a suit, the money belonged to him. Finally, symbolic of this loss of a separate identity, the woman was required to assume her husband's name upon marriage. See, e.g., Whitlow v. Hodges, 539 F.2d 582 (6th Cir.), cert. denied, 429 U.S. 1029 (1976); Forbush v. Wallace, 341 F. Supp. 217 (D. 
the late 1800 's, the law recognized women's existence. ${ }^{12}$ But two legal constructs enforced the subservience of women and the dominance of men in the home and wage market: first, the creation of separate spheres for men and women and, second, enactment of limits on women's power to control reproductive capacity.

Assumptions about biological difference and destiny provided the prime justification for creating a separate, inferior legal status for women. ${ }^{13}$ The law denied women equal opportunity for wage work

Ala. 1971), affd, 401 U.S. 970 (1972); see also Lamber, A Married Woman's Surname: Is Custom Law?, 1973 WASH. U.L.Q. 779, 783-95 (1973).

Although the woman gained certain protections through marriage-immunity from her debts, torts, and certain criminal actions, as well as an almost unenforceable right to support-she was severely handicapped in her ability to function in the public sphere. The laws regarding married persons "ha[ve] worked out in reality to mean that though the husband and wife are one, the one is the husband." United States v. Yazell, 382 U.S. 341, 361 (1966) (Black, J., dissenting). For further readings on the topic, see B. Babcock, Sex Discrimination, supra note 9; L. Kanowitz, Women and THE LAW: The UnFINISHEd Revolution (1969).

12 See Johnston, Sex and Property: The Common Law Tradition, the Law School Curriculum, and Development Toward Equality, 47 N.Y.U. L. REv. 1033 (1972).

13 Justice Bradley's concurrence in Bradwell v. Illinois, 83 U.S. (16 Wall.) 130 (1873), is the classic statement of the 19th century view of a woman's place in this society:

[T]he civil law, as well as nature herself, has always recognized a wide difference in the respective spheres and destinies of man and woman. Man is, or should be, woman's protector and defender. The natural and proper timidity and delicacy which belongs to the female sex evidently unfits it for many of the occupations of civil life. The constitution of the family organization, which is founded in the divine ordinance as well as in the nature of things, indicates the domestic sphere as that which properly belongs to the domain and functions of womanhood. . . .

[T]he paramount destiny and mission of woman are to fulfill the noble and benign offices of wife and mother. This is the law of the Creator. And the rules of civil society must be adapted to the general constitution of things ....

Id. at 141-42 (Bradley, J., concurring).

In Muller v. Oregon, 208 U.S. 412 (1908), the Court again viewed women's ana'tomy as destiny:

That woman's physical structure and the performance of maternal functions place her at a disadvantage in the struggle for subsistence is obvious. This is especially true when the burdens of motherhood are upon her. Even when they are not, by abundant testimony of the medical fraternity[,] continuance for a long time on her feet at work, repeating this from day to day, tends to injurious effect upon the body, and as healthy mothers are essential to vigorous offspring, the physical well-being of woman becomes an object of public interest and care in order to preserve the strength and vigor of the race.

Id. at 421 .

Employment was not the only area in which the Court used "natural" differences between the sexes to justify laws denying women the rights and responsibilities of male citizens. Women and the blind were given special "protection" by a Georgia statute requiring payment of a poll tax. "In view of burdens necessarily borne by them for the 
and participation in public life. ${ }^{14}$ It reinforced social and religious commitment to family-centered child rearing. Women were required, by law and custom, to care for men and children. ${ }^{15}$ Although women and children were and are entitled to look to men for financial support, that expectation was and is not theoretically enforceable during an ongoing marriage $^{16}$ nor as a practical matter when marriage ends. ${ }^{17}$

preservation of the race, the State reasonably may exempt [women] from poll taxes." Breedlove v. Suttles, 302 U.S. 277, 282 (1937). Unlike the blind, however, women were only exempt if they did not register to vote. In effect, the statute alleviated the tax burden by discouraging women from participating in the political process. Id.

14 The need for a woman to "proper[ly] discharge ... her maternal function" justified the maximum hours law in Muller v. Oregon, 208 U.S. 412, 422 (1908), and other laws "protecting" women by limiting their employment opportunities. See Women's Bureau, OfFice of THe SeCRETary, U.S. DeP'T of Labor, SumMary of State LABOR LAwS FOR WOMEN (1969), reprinted in The "Equal Rights" Amendment: Hearings on S.J. Res. 61 Before the Subcomm. on Const. Amendments of the Senate Comm. on the Judiciary, 91st Cong., 2d Sess. 729 (1970); Oldham, Sex Discrimination and State Protective Laws, 44 DEN. L.J. 344 (1967).

These laws helped create the sex segregated job market, with the more lucrative positions reserved for men. See generally Blumrosen, Wage Discrimination, Job Segregation and Women Workers, 6 Women's RTS. L. REP. 19 (1979-80); Ross, Sex Segregation and "Protective" Labor Legislation, reprinted in The "Equal Rights" Amendment: Hearings on S.J. Res. 61 Before the Subcomm. on Const. Amendments of the Senate Comm. on the Judiciary, 91st Cong., 2d Sess. 392 (1970). Further, sex segregation in employment has not decreased in recent years and some indicators show it is actually increasing. See Women's BuREau, U.S. DEP'T OF LABOR, 1975 HaNDBoor on WOMEN Workers (1975); see also U.S. CoMmission ON Grvil Rights, Social. INDICATORS OF EQUALITY FOR MINORITIES AND WOMEN (1978). When women-only protective labor laws were in force, employers could completely disqualify women from jobs by defining a job as requiring overtime, night work, or heavy lifting. Maximum hour laws denied women higher paid overtime work. Finally, forced maternity leaves denied women work and seniority, see, e.g., the policies struck down in Nashville Gas Co. v. Satty, 434 U.S. 136 (1977), and Gleveland Bd. of Educ. v. LaFleur, 414 U.S. 632 (1974). These protective laws gave women the option of staying at home or taking employment in lower paid, less desirable jobs.

${ }_{16}$ On the assumption that parents bear primary responsibility for the care and nurture of children, see Pierce v. Society of Sisters, 268 U.S. 510, 534-35 (1925); Meyer v. Nebraska, 262 U.S. 390, 401-02 (1923). The presumption that mothers rather than fathers bear primary responsibility for the home and the nurture of children is pervasive and has often been proffered as the justification for public policies providing differential treatment for men and women. See, e.g., Califano v. Westcott, 443 U.S. 76, 89 (1979); Orr v. Orr, 440 U.S. 268, 283 (1979); Hoyt v. Florida, 368 U.S. 57 (1961); see also infra notes 135-61 and accompanying text.

${ }_{18}$ In Crozier, Marital Support, 15 B.U.L. Rev. 28 (1935), the economic relation between husband and wife was analogized to that between master and slave.

Under what may be called the normal circumstances of marriage, her right of support is the right to live with him. . . .

So long as the spouses are living together, the wife's right of support is not a right to any definite thing or to any definite amount even in proportion to the husband's means. Depending on his personality, and hers, the chances-which have nothing to do with legal rights-may be either that she will with difficulty get an inadequate subsistence or that she will live in idleness and luxury. This is precisely the situation in which property finds itself; it may be overworked and underfed, or it may be petted 
For most of the twentieth century, the law also preserved the dominance of men by creating obstacles to women's ability to control their reproductive capacity. Beginning in the mid-1800's the law restricted access to contraception and abortion. ${ }^{18}$ Sex outside of marriage was condemned, by society and the law, much more harshly and consistently for women than for men. ${ }^{19}$ If an unmarried woman became pregnant,

and fed with cream, and that is a matter for the owner to decide.

Id. at 33. For a more modern perspective on the support/service dichotomy, see B. Babcock, Sex Discrimination, supra note 9, at 619-31.

17 D. Chambers, Making Fathers Pay: The Enforcement of Child SupPORT (1979).

${ }^{18}$ For a discussion, see Roe v. Wade, 410 U.S. 113, 138-44 (1973); Griswold v. Connecticut, 381 U.S. 479 (1965).

10 The sexual double standard creates differing sexual roles and expectations in society for men and women. Men are to be sexually aggressive; women are to have no sexual drives at all. See, e.g., infra notes 175-80 and accompanying text. The double standard gives women two options: to fulfill their assigned role as asexual and be revered or to accept their sexuality and endure society's condemnation. The laws reflect both choices by protecting "virginal" women and punishing women who express their sexuality.

Criminal law protects both a woman's reputation and her physical chastity. Some states penalize impugning the chastity of a woman. For example, Oklahoma makes it a crime to "orally or otherwise, falsely and maliciously . . . impute to any female, married or unmarried, a want of chastity." OkLA. Stat. ANN. tit. 21, § 779 (West 1983); see also Fla. Stat. AnN. § 836.04 (West 1976); Wash. Rev. Code ANN. § 9.58.110 (1977). Seduction is the crime of persuading a chaste woman to have sexual intercourse using some form of deception; some states require that there be a false promise to marry the woman. "[A] man who induces a woman to surrender her chastity by flattery, promises or artifice" may be guilty of seduction. 70 AM. JuR. 2D Seduction $\S 1$ (1973).

Statutory rape laws traditionally punished men for consensual intercourse with a female under a certain age. The age has ranged from as young as 10 to as old as 20 . See Comment, The Constitutionality of Statutory Rape Laws, 27 UCLA L. Rev. 757, 762 (1980) [hereinafter cited as Comment, Statutory Rape]; Comment, Forcible and Statutory Rape: An Exploration of the Operation and Objectives of the Consent Standard, 62 YALE L.J. 55, 76 (1952). ("[T]he law of statutory rape must intervene to prevent what is predicted will be an unwise disposition. And prevention is sought . . . by sanctioning the male, who is always assumed to be responsible for the occurrence.").

Prostitution laws provide a classic example of the law's sexual double standard. Some prostitution laws apply only to women, and facially neutral laws are enforced primarily against them. Brown, Emerson, Falk \& Freedman, The Equal Rights Amendment: A Constitutional Basis for Equal Rights for Women, 80 YALE L.J. 871, 962-63 (1971) [hereinafter cited as Brown, ERA Article]. Prostitution is defined as "the practice of a female offering her body to indiscriminate sexual intercourse with men," 63 AM. JuR. 2d Prostitution $\S 1$ (1972), or submitting "to indiscriminate sexual intercourse which she invites or solicits." Id. She "solicits" then "submits." A woman who will have sex with many men is a "common prostitute" and a criminal while a sexually active man just has a healthy sex drive.

Young women whose chastity is not "saved" through statutory rape laws may be subject to various sanctions. Until the 1970's, pregnant high school students were commonly expelled from school. In Texas in 1971, "[o]f 119 school districts, 105 compelled pregnant girls to withdraw from regular classes. Of those 105,55 offered no substitute services . . . Comment, Marriage, Pregnancy, and the Right to Go to School, 50 Tex. L. REv. 1196, 1196 n.3 (1972). Boys who fathered the children were free to 
she needed to persuade a man to marry her. The law did not compel a

continue their education. Ordway v. Hargraves, 323 F. Supp. 1155 (D. Mass. 1971), held this type of school policy a possible violation of the Civil Rights Act. Title IX of the Education Amendments of 1972, Pub. L. No. 92-318, § 901, 86 Stat. 373 (1972), prohibits sex discrimination in education programs receiving federal aid; federal regulations prohibit discrimination against students on the basis of pregnancy. See 34 C.F.R. $\S 106.21(\mathrm{c})(2)(1983)$.

Young women who are sexually active may be punished through the juvenile justice system. A study of the New York system in 1974 found allegations of promiscuity, prostitution, cohabitation, and general sexual innuendo were made exclusively against females; all these allegations were grounds for a finding of "ungovernability." Note, Ungovernability: The Unjustifiable Jurisdiction, 83 YALE L.J. 1383, 1388-89 n.41 (1974).

The punishment of women who violate the double standard is reflected in literature as well as laws. The classic literary example is The Scarlet Letter by Nathaniel Hawthorne. The adulteress, Hester Prynne, was made to bear the scorn and condemnation of society symbolically displayed by a scarlet " $A$ " for adulteress on her chest. Because she became pregnant, her indiscretion was publicly known. Her lover's identity, however, remained a secret. Hester actually may have been better off than other sexually active women in literature; she and her child both survived. Hemingway's Catherine in A Farewell to Arms died in childbirth after having an illicit affair; the child was also born dead. In Thomas Hardy's Tess of the D'Urbervilles, Tess's husband confessed to her his sexual past. She then confessed to him that after being raped she had borne a child that died. Her husband abandoned her and she returned to a sexual relationship with the man who had raped her. Eventually she killed him and was executed for his murder. The sexual woman either lives a condemned life or dies as payment for her sexual behavior.

In recent years, the prohibition on women's sexuality has eroded. The prevalence of sexual activity among never-married American teenage women increased by $30 \%$ between 1971 and 1976, so that by age 19,55\% have had sexual intercourse. The increase has occurred at all ages and among all races. Zelnik \& Kantner, Sexual and Contraceptive Experience of Young Unmarried Women in the United States, 1976 and 1971, 9 Fam. Plan. Perspectives 55 (1977).

Change is observable in the proliferation of such works as I. KASSORLA, NICE Girls Do (1980); G. Masterton, How to Drive Your Man Wild in Bed (1976); M. Sands, The Mistress' Survival Manual (1982), and in the latest scenes of pre-marital and extra-marital sex in the movies and on television. Sex is ever more explicitly used to sell books, magazines, and movies as well as perfumes, cars, and jeans.

Whether this "sexual liberation" is really liberating is a different question.

Sexual health, measured either physically or psychologically, is in some respects deteriorating, as evidenced in spreading venereal disease, rape, and sexual encounters stripped of obligations between people as subjects. ... .

The problem with the commercialization of sexual pleasure is not merely that it fosters fragmented sexual experience. These new permissive standards and practices remain fundamentally deformed by male-supremacist practices and attitudes and a heightened instrumentalism, people using one another as mere tools for personal satisfaction. . . .

As men once took advantage of the sexual double standard and the enforced chastity of their wives, now they often take advantage of the niythical single standard to belittle and pressure women who resist their sexual preferences. Thus the area of sexual relationships remains . . a major battlefield for feminists.

L. Gordon, Woman's Body Woman's Right 412-14 (1976). 
man to take responsibility for the pregnancy he had helped to cause or the child he had helped to create. ${ }^{20}$ The law condemned the child as a bastard and subjected the child to significant legal disabilities. ${ }^{21}$ Laws disfavoring the children of an unmarried woman encouraged her sexual purity and made the social and economic status of both the child and mother "ultimately dependent upon the male."22

Legal structures that support the dominance of men and subservience of women are fundamentally inconsistent with constitutional ideals of individual worth and equality of opportunity. It is crucial to understand, then, why contemporary constitutional sex equality doctrine evidences a lack of concern about the implications of state regulations that are based on biological differences and have been prominent in establishing and perpetuating the inequality of women. The next two sections explore first the conceptual and then the historical factors that may indicate why our present equality doctrine carefully scrutinizes explicit sex-based classifications while essentially ignoring laws governing sex-based biological differences. This history also demonstrates that the development of sex equality doctrine that excludes concern for sex-specific biology occurred at the same time the Supreme Court recognized a privacy-based right of reproductive freedom. The result of this history is that we have been virtually blinded to the relevance of equality notions when evaluating state limitations on a woman's access to abortion.

The third section of the article discusses another consequence of the Court's failure to focus on the myth and reality of biological differences: the Supreme Court now justifies deferential scrutiny of explicit sex-based classifications that raise significant problems of sex equality by finding that the laws are based on "real" differences between men and women.

Section IV presents my central thesis that sex equality doctrine must confront squarely the reality of categorical biological differences between men and women. To reconcile the ideal of human equality with the reality of biological difference we must (1) begin to distinguish clearly between laws that classify on the basis of sex and laws that

20 See infra notes 131-37 and accompanying text.

21 The concept of illegitimacy was created to insure male dominance. See H. Krause, Illegrtimacy: Law and Social Policy 83 (1971). Krause argues that the problem of illegitimacy must be solved by maximizing paternity determinations. For a defense of the mother/child family, see Book Review, 19 UCLA L. REv. 845 (1972); see also Weber v. Aetna Casualty \& Surety Co., 406 U.S. 164 (1972) (denial of equal recovery rights to illegitimate children violates equal protection clause); Levy v. Louisiana, 391 U.S. 68 (1967) (denial of recovery right for illegitimate children violates equal protection clause).

${ }^{22}$ K. Miliete, Sexual Politics 35 (1970). 
govern reproduction; (2) recognize that laws governing reproduction implicate equality concerns; and (3) establish a test that can determine when laws governing reproduction violate constitutional equality norms. The test proposed here will then be applied to a variety of governmental policies, including limits on access to abortions. This application indicates the value of a unified approach to sex equality.

\section{Visions of SeX-Based Equaltty}

Legal concepts of equality are informed by social vision. A growing literature attempts to give concrete content to social visions of sexual equality. ${ }^{23}$ In legal doctrine the dominant vision of sex equality is an assimilationist one, which conceives of a society in which sex would be a wholly unimportant characteristic of individuals, having no greater significance than eye color has in our own society. ${ }^{24}$ The assimilationist ideal posits that some characteristics-race, sex, eye color-do not describe differences that should ever be allowed to matter in any significant way. Even in the most personal social relations, an individual who selected friends on the basis of eye color would be regarded as idiosyncratic. The assimilationist vision asserts that it is unjust to distribute rights or responsibilities on the basis of distinctions that do not ever describe relevant differences-sex, race, or eye color. This vision is best developed in relation to race. The assimilationist view of sex equality is attractive to constitutional lawyers because it builds upon analogies between race- and sex-based discrimination.

The analogies between race- and sex-based discrimination are powerful. ${ }^{25}$ Blacks and women share a similar history of oppression; prior to the Civil War the laws defining the status of blacks and women borrowed freely from one another. ${ }^{26}$ Sex, like race, is an immu-

${ }^{23}$ See, e.g., G. Gilligan, In A Different Voice (1982); Jaggar, On Sexual Equality, 84 ETHics 275 (1974); Scales, supra note 7; R. WASSERSTROM, Racism and Sexism, in Philosophy and Social Issues: Five Studies 11 (1980); Wasserstrom, Racisin, Sexism, and Preferential Treatment: An Approach to the Topics, 24 UCLA L. REv. 581 (1977) [hereinafter cited as Wasserstrom, Topics].

24 Wasserstrom, Topics, supra note 23 , at 585-86. Wasserstrom urges that we differentiate three different perspectives in thinking about racism or sexism. One perspective considers the way our society currently exists with respect to sex or race: the "social reality." The second perspective considers how things ought to be in relation to sex or race: the "ideal." The third considers the best mechanism for the transition from the "social reality" to the "ideal." Separating these three perspectives helps provide a framework for analyzing affirmative action. Id. at $581,583$.

${ }^{25}$ For a criticism of the analogy between racism and sexism, see B. Hooks, Ain'T I A WOMAN 19-58 (1981).

${ }^{26}$ S. De Beauvoir, The Second Sex xxïi (1968); G. Myrdal, An American Dilemma 1073-78 (1944); Fitzhugh, Sociology for the South, in Slavery Defended 34 (E. McKitrick ed. 1963). 
table and highly visible characteristic. ${ }^{27}$ Women, like blacks, continue to occupy a position of economic inferiority. Indeed, as compared to white men, women are more economically disadvantaged than blacks, and black women are doubly disadvantaged. ${ }^{28}$ Although women are not a minority, they were denied the franchise until 1920, and today women exercise limited political power. ${ }^{29}$ Finally, and most impor-

${ }^{27}$ See Hacker, Women As a Minority Group, 30 Social Forces 60 (1951). Not all immutable characteristics are suspect, for example height or lefthandedness. For a discussion, see Tribe, The Puzzling Persistence of Process-Based Constitutional Theories, 89 YALE L.J. 1063, 1072-79 (1980). But sex seems significantly more important than other physical characteristics and, apart from reproduction, bears little relation to individual ability to perform or contribute.

${ }^{28}$ In 1939 the median income of full-time full-year workers was:

$\begin{array}{lr}\text { white men: } & \$ 1,419 \\ \text { white women: } & 863 \\ \text { black men: } & 639 \\ \text { black women: } & 327\end{array}$

By 1964 the relative economic positions of white women and black men had shifted:

$\begin{array}{lr}\text { white men: } & \$ 6,497 \\ \text { black men: } & 4,285 \\ \text { white women: } & 3,859 \\ \text { black women: } & 2,674\end{array}$

Women's Bureau, U.S. DeP'T of Labor, Office of the Secretary, Fact Sheet on the Relative Position of Women and Men Workers in the Economy (1981). By 1979, the gap between males and females had grown quite large:

$\begin{array}{lr}\text { white men: } & \$ 12,372 \\ \text { black men: } & 7,743 \\ \text { white women: } & 4,394 \\ \text { black women: } & 4,023\end{array}$

Sex Discrimination in the Workplace, 1981: Hearings Before the Subcommittee on Labor of the Senate Comm. on Human Resources, 97th Cong., 1st Sess. (1981).

Among year-round, full-time workers, the median income of black, male high school graduates exceeds that of white female college graduates. BUREAU of CENSUS, U.S. Dep't of Ccmmerce, Current Population Reports, Consumer Income: Money Income of Households, Families and Persons in the United States: 1980.

${ }^{20}$ In 1982 only $6.9 \%$ of federal judges and $12.1 \%$ of state legislators were women. In the Congress there were two women in the Senate and 19 women in the House in 1982. Statistics from Eagleton Center for the American Woman and Politics, Rutgers University, New Brunswick, N.J. The Supreme Court has recognized that sometimes a numerical majority must be treated like a minority for purposes of equal protection analysis. In Castaneda v. Partida, 430 U.S. 482 (1977), the Court held that a prima facie case of discrimination against Mexican-Americans in the selection of grand jurors was not constitutionally affected by the fact that Mexican-Americans had a "governing majority" in the affected county. Justice Marshall explained, "Social scientists agree that members of minority groups frequently respond to discrimination and prejudice by attempting to disassociate themselves from the group, even to the point of adopting the majority's negative attitudes towards the minority." Id. at 503 (Marshall, J., concurring). Certainly part of the reason for the second-class status of women is that they accept the stereotypes of their own inferiority. 
tantly, sex, like race, "frequently bears no relation to ability to perform or contribute to society."

Although these factors support the conclusion that classifications based on sex, like those based on race, should be regarded as constitutionally suspect, there are also important points of difference between sex- and race-based discrimination. There is no reason to believe that black and white people are inherently different in any way that should ever be allowed to matter in the law. ${ }^{31}$. Men and women, by contrast, are different in significant sex-specific physical ways. Most differences between men and women are like differences between blacks and whites: statistical generalizations, which are more or less true in the aggregate but untrue in relation to particular individuals. Accurate statistical differences between men and women that are false in individual cases include weight, height, longevity, mathematical aptitude, aggression, capacity for nurturance, and physical strength. There are, however, other categorical differences between men and women that are not simply statistical generalizations, but rather sex-based physical differences relating to reproductive capacity. By categorical sex-based differences, what is meant, and all that is meant, is that most women and no men possess the capacity to reproduce the species. This concept of categorical sex-based differences is not merely definitional but is grounded

John Ely, exploring this point, concludes, "To apply all this to the situation of women in America in $1980, \ldots$ is to strain a metaphor past the breaking point." J. Ely, Democracy and Distrust: A Theory of Judicial Review 166 (1980). He argues for relatively more rigorous scrutiny of sex-based laws of older vintage, enacted when women were barred from the political process, but asserts that "if women don't protect themselves from sex discrimination in the future, it won't be because they can't." Id. at 69. One way in which oppression is perpetuated is to assume falsely that equality has been achieved, when it has not. On the other hand, recognition of the reality of oppression, particularly in the case of women, can perpetuate derogatory stereotypes. The tension between these two dangers is persistent. Ely overestimates the degree to which sex-based equality has already been achieved.

Today, every woman over 30 came to maturity in a world in which virtually no one questioned the assumption that the woman's place was in the home and her function in life was to find and keep a man. Exercise of significant ambition today demands a single-minded, egotistic devotion that is inconsistent with primary responsibility for the care of children. For all the changes in attitudes toward women since 1970, there has been little increase in male responsibility for nurturing or in the development of other forms of child care that would free women for the intense work that exercising political power demands. See infra notes 158-64 and accompanying text. On the other hand, women who aspire to political office seem to be held to a very high standard to avoid the appearance of being excessively driven or lacking nurturing qualities.

so Frontiero v. Richardson, 411 U.S. 677, 686 (1973) (plurality opinion).

s1 Although the prevalence of sickle cell anemia in black Americans is arguably a race-specific physical difference between blacks and whites, this is not comparable to sex-based differences in reproductive capacity. Only one quarter of one percent (.25\%) of American blacks have the disease, and only $8 \%$ are sub-clinical carriers of the sickle cell trait. Thompson \& Thompson, Genetics IN MEDICINE 101 (1980). 
in physical reality.

The assimilationist presumption that sex-based differences are always insignificant is false. Although both law and culture exaggerate the significance of biological differences, changes in social, cultural, and legal arrangements could not make these differences disappear. Absent development of a practical means to reproduce people outside a woman's body, a technological development not now on the horizon, ${ }^{32}$ it is implausible to suggest that sex-based biological differences are wholly insignificant. An assimilationist vision that ignores differences between men and women does not help us to reconcile the ideal of equality with the reality of difference.

A second vision of a sexually equal society recognizes differences in the life experience of men and women, in relation to biology, psychology, and moral development. The social reality that children are raised by women means that the process of psychological maturation is different for boys and girls. ${ }^{33}$ Socially developed concepts of gender de-

s2 Test-tube babies, produced from embryos fertilized in vitro, are not brought to term in a laboratory. Shortly after fertilization, the embryo must be implanted in a woman's uterus where it will complete its development for the normal period of gestation. Treichel, American's First Test-Tube Baby, 121 ScI. News 7 (Jan. 2, 1982). Thus, the test-tube baby is in fact only a test-tube conception. The mature fetus is carried and delivered by a woman through normal reproductive processes. Even such "'test-tube' births are still extraordinary medical events." Id.

In animal research the technology of artificial reproduction is further advanced, but, even here, science is far from full reproduction without implantation into the womb of an adult female of the same species. Though scientists were first able to culture fertilized mouse ova, for example, about 15 years ago, they have only recently reported culturing the developing mouse embryo for ten days prior to implantation. See Chen and Hsu, Development of Mouse Embryos In Vitro: Preimplantation to the Limb Bud Stage, 218 ScI. 66 (Oct. 1, 1982). Ten days is half of the normal gestation period for mice. Mouse Embryos Reach Advanced Stage in Lab Dish, N.Y. Times, Oct. 5, 1982, C3, col. 1. This was the first known successful attempt to grow mouse embryo in vitro to such an advanced stage of development. Id. This extraordinary accomplishment could not readily be repeated in other laboratories.

s3 For example, Nancy Chodorow argues that female identify formation takes place in a context of ongoing relationship since "[m]others tend to experience their daughters as more like, and continuous with, themselves." N. CHODOROw, THE REPRODUCTION OF MOTHERING 166 (1978). She asserts that girls, in identifying themselves as female, experience themselves as like their mothers, thus fusing the experience of attachment with the process of identity formation. In contrast, "mothers experience their sons as a male opposite," and boys, in defining themselves as masculine, separate their mothers from themselves, thus curtailing "their primary love and sense of empathic tie." Id. Consequently, male development entails a

more emphatic individuation and a more defensive firming of experienced ego boundaries. . . . Girls emerge with a stronger basis for experiencing another's needs or feelings as one's own (or of thinking that one is so experiencing another's needs and feelings). . . . From very early, then, because they are parented by a person of the same gender . . . girls come to experience themselves as less differentiated than boys, as more continuous with and related to the external object-world, and as differently ori- 
fine different expectations and value different qualities in males and females. $^{34}$ Carol Gilligan, for example, describes differences in the moral character of men and women. ${ }^{35}$ Often, for men "leaving childhood means renouncing relationships in order to protect [their] freedom of self-expression, . . . [while for women] 'farewell to childhood' means relinquishing the freedom of self-expression in order to protect others and preserve relationships."38 Men tend to be concerned with rights, hierarchical relationships, and personal achievement while women are concerned with caring and personal relationships.

The images of hierarchy and web, drawn from the texts of men's and women's fantasies and thoughts, convey different ways of structuring relationships and are associated with different views of morality and self. . . . As the top of the hierarchy becomes the edge of the web and as the center of a network of connection becomes the middle of a hierarchical progression, each image marks as dangerous the place which the other defines as safe. Thus, the images of hierarchy and web inform different modes of assertion and response: the wish to be alone at the top and the consequent fear that others will get too close; the wish to be at the center of connection and the consequent fear of being too far out on the edge. These disparate fears of being stranded and being caught give rise to different portrayals of achievement and affiliation, leading to different modes of action and different ways of assessing the consequences of choice. ${ }^{37}$

The strength of a vision of differences is that it recognizes the social importance of traditional female virtues of nurturing, responsibility to others, and concern with relationships. In a society dominated by

ented to their inner object-world as well.

Id. at 16. See also D. Dinnerstein, The Mermaid and the Minotaur: Sexual ARrangements and Human Malaise (1977); Sassen, Success Anxiety in Women: A Constructivist Interpretation of its Sources and its Significance, 50 HARv. EDuc. REv. (1980). For an excellent critique of Chodorow, arguing that her analysis gives too much weight to early psychological development and too little to the legal and social structures that enforce women's inferiority, see Lorber, Coser, Rossi \& Chodorow, On The Reproduction of Mothering: A Methodological Debate, 6 SIGNS: J. WOMEN IN Culture \& Soc'y 482 (1981).

34 Ross \& Rapp, Sex and Society: A Research Note from Social History and Anthropology, in Powers of Desire: The Politics of SeXuality 51 (A. Snitow, C. Stansell \& S. Thompson ed. 1983); see also Baker, Biological Influences on Human Sex and Gender, 6 Signs: J. Women in Cuzture \& Soc'y 80 (1980).

ss C. Gilligan, supra note 23.

ss Id. at 157 .

${ }^{32}$ Id. at 62 . 
traditional male values, "assimilation" seems often to mean assimilation to a male norm. ${ }^{38} \mathrm{~A}$ vision of equality that incorporates respect for differences between men and women hence places a higher value on women's traditional virtues and work.

People have attempted to articulate a constitutional sexual equality doctrine that would value traditional female characteristics. For example, Elizabeth Wolgast advocates a constitutional idea of sex-based equality grounded on diversity and tolerance that would recognize the significance of sex-based differences and allow those differences to be institutionalized and valued. At the same time, her theory would attempt to mitigate the oppressive aspects of existing sex roles. ${ }^{30}$ This vision borrows from the ideals of tolerance embodied in the first amendment's religion clauses. ${ }^{40}$ Catharine MacKinnon advocates a standard that would ask simply whether laws challenged as sex-discriminatory empower women and enable them to participate as full members of the society. ${ }^{41}$

The difficulty with an ideal of a sexually equal society that respects psychological and moral differences between men and women is that many of these differences are socially created. Gilligan recognizes that the differences she describes are "not absolute. . . . Clearly, these differences arise in a social context where factors of social status and power combine with reproductive biology to shape the experience of males and females." ${ }^{\prime 2}$ There is a great danger that affording legal respect to presumed sex-based differences will perpetuate those differences. Furthermore, general rules premised on assumptions of universal sex-based difference are unjust in relation to the individual men and women who do not fit the presumed norm.

A constitutional theory based on either the assimilationist vision or the respect-for-difference vision presumes that it is possible to answer the question, "Are men and women essentially similar?," with a simple yes or no. The assimilationist principle answers the question "yes" and condemns laws that treat people differently. The respect-for-difference principle emphasizes that, at least under present social conditions, the situations of men and women are not essentially similar, and it would (1981).

s8 Note, Toward A Redefinition of Sexual Equality, 95 Harv. L. REv. 487

39 E. Wolgast, Equality AND the Rights of WOMEN (1980); see also Rutherglen, Sexual Equality in Fringe-Benefit Plans, 65 VA. L. REv. 199, 205-16 (1979).

40 See also Wasserstrom, Topics, supra note 23, at 604-05.

41 C. MacKinnon, Sexual Harassment of Working Women: A Case of Sex Discrimination (1979).

42 C. Gilligan, supra note 23 , at 2. 
evaluate laws affecting men and women differently by asking whether they empower and respect women.

A third vision, and the one that informs this article, assumes that it is not possible to give a single answer to the question whether men and women are essentially similar. We know that there are biological differences between men and women in relation to reproduction. These differences have been used to justify sex-based legal and cultural limitations on human potential that do not reflect any real difference between men and women ${ }^{43}$ and that enforce the inferiority of women and the dominance of men. The vision of equality advocated here suggests that the appropriate function of the law is not to enforce a general vision of what men and women are really like, but rather to respect each person's authority to define herself or himself, free from sex-defined legal constraints. ${ }^{44}$ Our ability to develop this equality principle is enhanced by focusing on the myth and reality of differences between men and women.

Neither the assimilationist vision nor the respect-for-difference vision squarely confronts the problem of reconciling sexual equality with the reality of biological differences. The assimilationist vision denies the significance of biological differences. The vision of respect for difference underestimates the difficulty of overcoming the legal constructs that give oppressive social significance to such differences and thereby limit human liberty and equality. The development of constitutional doctrine in the past fifteen years has also failed to reconcile the idea of equality with the reality of biological difference, in part because of the failure of these dominant concepts of equality and in part because of the historical development of constitutional doctrine. A brief examination of this history reveals some of the reasons for the failure to develop a theory of sexual equality that addresses the biological differences between women and men.

\section{Removing Biology from Sex Equality-A Review of the Development of Constitutional Doctrine}

This section describes the historical antecedents of the two anomo-

4 Dress rules provide a graphic example of legal and cultural sex role constraint not justified by biology. Men can't wear skirts. It is surely not biology that prevents them from doing so. See Whisner, Gender-Specific Clothing Regulation: A Study in Patriarchy, 5 HARv. Women's L.J. 73 (1982).

14 Of course it is not simply sex-based constraints that inhibit people's capacity for self-definition. There are profound race- and class-based differences in the opportunities for significant life choices available to people. See Law, Women, Work, Welfare and the Preservation of Patriarchy, 131 U. PA. L. Rev. 1249 (1983). 
lies in constitutional sex equality doctrine: the lack of an analytic framework for assessing the relevance of biological differences and the absence of sex equality principles from the constitutional reproductive freedom doctrine.

\section{A. The 1960's: Political Organizing and Consciousness-Raising}

During the 1960's, the civil rights movement inspired many Americans to grapple with the ideal of equality and the difficulty of achieving it. Millions of blacks and whites saw the pervasiveness and subtlety of racism. It is quite astonishing that throughout the decade, as the Supreme Court decided cases that addressed issues of race discrimination and expanded concepts of constitutional equality beyond their historic racial core, ${ }^{45}$ the Court never applied ideals of equality to sexbased limitations. ${ }^{48}$ Through most of the 1960's few observed the paral-

4s See, e.g., Shapiro v. Thompson, 394 U.S. 618 (1969); Levy v. Louisiana, 391 U.S. 68 (1968); Rinaldi v. Yeager, 384 U.S. 305 (1966); Baxstrom v. Herold, 383 U.S. 107 (1966).

to The Warren Court never directly confronted claims brought by women asking for equal treatment under the law. Three cases did discuss women's equality issues. Hoyt v. Florida, 368 U.S. 57 (1961), involved an equal protection claim raised in a criminal trial. The female defendant claimed that automatic exemption of women from juries violated her sixth and fourteenth amendment rights to a fair trial by jury. The claim was particularly appropriate since the defendant was charged with murdering her husband, and women jurors might well have had a different perspective. The Court rejected her claim, finding that because "woman is still regarded as the center of home and family life" the state could exempt her from jury duty. See id. at 62 .

The Warren Court's decision in United States v. Yazell, 382 U.S. 341 (1966), also involved underlying issues of women's equality. Ms. Yazell used the defense of coverture to avoid liability on a federally financed loan made to her and her husband. She claimed that under Texas law a married woman could not contract without judicial permission. The court focused on whether federal or state law should govern and allowed coverture to protect the woman from liability on the debt. Justice Black, dissenting, condemned the law of coverture as an "archaic remnant of a primitive caste system." Id. at 361 (Black, J., dissenting).

Finally, the Warren Court summarily affirmed, in Williams v. McNair, 401 U.S. 951 (1971), the lower court's decision which had rejected the equal protection claim of a man who was denied admission to an all-female state college. But see Mississippi Univ. for Women v. Hogan, 458 U.S. 718 (1982) (policy excluding men from state nursing school violates equal protection clause).

During this period the lower courts considered sex-equality claims more directly. Women challenged laws that gave men, but not women, the right to sue for loss of consortium. See, e.g., Miskunas v. Union Carbide Corp., 399 F.2d 847 (7th Cir. 1968), cert. denied, 393 U.S. 1066 (1969); Krohn v. Richardson-Merrell, Inc., 219 Tenn. 37, 406 S.W.2d 166 (1966), cert. denied, 386 U.S. 970 (1967). A policewoman challenged the added requirement of an oral exam for female but not male candidates for sergeant. See Wells v. Civil Service Comm'n, 423 Pa. 608, 225 A.2d 554, cert. denied, 386 U.S. 1035 (1967). Women also sought to force states to open all their colleges to women as well as men. See, e.g., Allred v. Heaton, 336 S.W.2d 251 (Tex. Civ. App. 1959), cert. denied, 364 U.S. 517 (1960); Heaton v. Bristol, 317 S.W.2d 86 (Tex. Giv. App. 1958), cert. denied, 359 U.S. 230 (1959). 
lels between racism and sexism that Gunnar Myrdal had so trenchantly documented in $1944 . .^{47}$ Nonetheless, the growth of consciousness supporting the aspiration of racial equality and the externally imposed and internally accepted stereotypes that prevented its achievement facilitated perception of the injustice of sex-defined legal and social constraints on human freedom. ${ }^{48}$

By the late 1960's many women had participated in the civil rights and antiwar movements and had learned new political skills. ${ }^{49}$ Also of invaluable importance to the struggle for women's rights were the consciousness-raising groups of the late 1960 's. $^{.0}$ Through these groups women discovered that their most intimate personal concerns were shared by other women and that their private, individual lives were

47 See G. Myrdal, supra note 26. In. fact, one ploy of some southern legislators to defeat the enactment of civil rights legislation was to include a prohibition against sex discrimination in Title VII of the Civil Rights Act of 1964. J.R. Pole, The PuRSUIT OF EQUALITY IN AMERICAN HISTORY 316 (1978).

48 There are parallels between the nineteenth and twentieth centuries: a high level of involvement of women in the struggle for racial liberation, an initial willingness on the part of women to defer the assertion of their own claims to the struggle for racial justice, and the eventual emergence of an expanded feminist consciousness, illuminated by an understanding of racism. For a discussion of the women's movement in the nineteenth century, see E. Flexner, Gentury of Struggle: The Women's Rights Movement IN THE UNITEd States (1975). For a discussion of the women's movement in the twentieth century, see J. Hole \& E. Levine, REBIRTH OF FEMINISM (1971); Introduction in Powers of Desire: The Politics of Sexuality 9 (A. Snitow, C. Stansell \& S. Thompson eds. 1983).

One commentator has argued that "[t]wice in the history of the United States the struggle for racial equality has been midwife to a feminist movement. In the abolition movement of the $1830 \mathrm{~s}$ and $1840 \mathrm{~s}$, and again in the civil rights movement of the 1960s . . . ."S. Evans, Personal Politics: The Roots of Women's Liberation IN The Givil Rights Movement and the New Lefr 24 (1979). See also N. MCGlen \& K. O'Connor, Women's Rights: The Struggle for Equality in the Nineteenth and Twentieth Centuries 23-24 (1983); V. Randall, Women and Politics 147-48 (1982). Some commentators have suggested that the National Organization for Women (NOW) was modeled after the National Association for the Advancement of Colored People (NAACP). See N. MCGLEN \& K. O'ConNoR, supra, at 24, 31; M. Ryan, Womanhood In AMerica 310-11 (3rd ed. 1983).

48 Involvement in the antiwar movement and other New Left activities is seen by several commentators as important to the development of the modern feminist movement. See N. MCGLEN \& K. O'CoNNOR, supra note 48, at 24-25 (importance of the "counterculture and student and antiwar movements" to modern feminism); V. RaNDALL, supra note 48, at 149 (experience in "New Left movements" was a "trigger" to the modern feminist movement); M. RYAN, supra note 48, at 310-11 (antiwar and New Left movements along with civil rights movement "catalyze[d]" the modern feminist movement).

In these movements women also learned the pervasive nature of sex discrimination. See, e.g., S. EvaNS, supra note 48, at 179-85; M. RYaN, supra note 48, at 311 (women in these movements "confronted some particularly grating exhibitions of misogyny.").

${ }_{B 0}$ For discussions of the importance of consciousness raising groups, see, e.g., N. MCGLEN \& K. O’ConNoR, supra note 48, at 24, 26; V. RaNDAlL, supra note 48, at $150,166$. 
shaped by deep social and cultural structures. These groups provided women with the solidarity and strength to seek transformation of themselves and society. ${ }^{ }$The contemporary revision of constitutional doctrine in relation to sex equality and reproduction is the product of these radical shifts in women's consciousness and behavior.

When women began challenging legal restraints on human liberty, their central focus was on laws denying women access to abortion. ${ }^{62}$

In a number of cities across the country there were women coming forward and saying, I had an abortion, I had an illegal abortion and this is how I had it, and telling the details. What was really happening to women day in and day out was no longer a matter of private horror and embarrassment but became a public issue. ${ }^{53}$

These women, in cooperation with medical, family planning, and religious groups, persuaded many state legislatures to liberalize criminal statutes prohibiting abortions. ${ }^{54}$

In 1969 women began integrating constitutional litigation into this organizational and educational effort. Suits often named hundreds and sometimes thousands of women as individual plaintiffs. ${ }^{55}$ Live testi-

51 This discussion is not intended to demean the importance to the modern feminist movement of women who worked for women's rights throughout the twentieth century. Such women have had a major impact. See, e.g., V. RaNDALL, supra note 48, at 148 .

62 The first constitutional challenges to restrictive abortion laws were defensive. They arose in response to criminal prosecutions of doctors charged with performing abortions or with aiding and abetting the crime by referring patients to illegal abortionists. See, e.g., United States v. Vuitch, 402 U.S. 62 (1971); People v. Belous, 71 Cal. 2d 954, 458 P.2d 194, 80 Cal. Rptr. 354 (1969), cert. denied, 397 U.S. 915 (1970). The arguments in these early cases challenged the vagueness of exceptions to anti-abortion statutes that allowed abortions where the woman's life or health was endangered and sought expansion of the privacy right recognized in Griswold v. Connecticut, 381 U.S. 479 (1965).

ss Goodman, Schoenbrod \& Stearns, Doe and Roe: Where Do We Go From Here?, 1 Women's RTS. L. RPTR. 20, 23 (1973); see also D. Schulder \& F. KENNEDY, ABORTION RAP (1971).

o4 By 1973, 14 states had adopted some form of Model Penal Code $§ 230.3$, which allowed abortions when the pregnancy would gravely impair the physical or mental health of the mother, when the child would be born deformed, or when pregnancy resulted from feloneous intercourse. Four other states repealed criminal penalties for abortions performed early in the pregnancy. See Roe v. Wade, 410 U.S. 113, 140 n.37 (1973).

so See, e.g., Doe v. Dunbar, 320 F. Supp. 1297 (D. Colo. 1970) (brought on behalf of hundreds of women); Abramowicz v. Lefkowitz, 305 F. Supp. 1030 (S.D.N.Y. 1969) (presented claims of hundreds of women). Abele v. Markle, 452 F.2d 1121 (2nd Cir. 1971), on remand, 342 F. Supp. 800 (D. Conn. 1972), vacated, 410 U.S. 951, on remand, 369 F. Supp 807 (D. Conn. 1973), was one of the few cases in which numbers of women were allowed to present testimony about the importance of abortion. The initial district court opinion struck down the restrictive law on grounds 
mony educated judges, lawyers, and the public about the impact of unwanted pregnancy upon women's lives. Women filled courtrooms, bringing babies and the coat hangers that symbolize illegal abortions. ${ }^{56}$ Despite women's paramount concern for the right to obtain abortions, the constitutionality of government restrictions on the right was not presented to the courts as a clear issue of sex equality. Rather, women challenged the abortion restrictions on two other grounds: first, the fourteenth amendment's guarantee of liberty, as explicated by the Supreme Court in Griswold $v$. Connecticut, ${ }^{\mathrm{st}}$ protected the right to an abortion; second, the fourteenth amendment's guarantee of equality precluded certain limits on the availability of abortions because they discriminated against poor and non-white women. ${ }^{58}$ In addition, in several major cases, these claims by women were joined by physicians' challenges to the abortion restrictions based on claims that the laws were impermissibly vague and violated the privacy of the doctor/patient relationship. ${ }^{50}$

\section{B. The 1970's: Invalidating Sex Classifications via the Fourteenth Amendment}

The Supreme Court did not apply the fourteenth amendment's guarantee of equality to invalidate a sex classification until 1971, near

that the fourteenth amendment's protection of women's liberty encompasses the right to decide whether to bear a child. It describes the impact of involuntary child bearing. See 342 F. Supp at 804. Abramowitz v. Kugler, 342 F. Supp 1048 (D.N.J. 1972), filed on behalf of 1.200 women, was dismissed for lack of standing, while a companion case on behalf of organizations and physicians held that the restrictive laws were unconstitutionally vague and violated privacy rights. See YWCA of Princeton, N.J. v. Kugler, 342 F. Supp. 1048 (D.N.J. 1972); Women of Rhode Island v. Israel, Civ. Nos. 4605 \& 4586 (D.R.I. 1973) (challenged restrictive abortion laws as perpetuating an inferior status prohibited by the nineteenth amendment) consolidated with Rhode Island Abortion Counseling Service v. Israel, Giv. No. 4586 (D.R.I. 1971). In Ryan v. Spector, Civ. No. 70-2527, (E.D. Pa. 1970), a three-judge court refused to dismiss a claim filed by over 1000 named women plaintiffs.

se Goodman, Schoenbrod \& Stearns, supra note 53, at 24-25.

3738 U.S. 479 (1965).

${ }^{88}$ Doe v. Bolton, 410 U.S. 179 (1973); Roe v. Wade, 410 U.S. 113 (1973); Abele v. Markle, 452 F.2d 1121 (2d Cir. 1971), on remand, 342 F. Supp. 800 (D. Conn. 1972), vacated, 440 U.S. 951 (1973), rehearing denied, 411 U.S. 940 (1973), on remand, 369 F. Supp. 807 (D. Conn. 1973); Babbitz v. McCann, 310 F. Supp. 293 (E.D. Wis. 1970), appeal dismissed, 400 U.S. 1 (1970); Abramowicz v. Lefkowitz, 304 F. Supp. 1030 (S.D.N.Y. 1969); People v. Belous, 71 Cal. 2d 954, 458 P.2d 194, 80 Cal. Rptr. 354, cert. denied, 397 U.S. 915 (1970) (first judicial language recognizing the fundamental right of abortion). ing lawyers.

See supra note 53 for sources containing discussion of these cases by participat- 
the beginning of the Burger Court era. ${ }^{60}$ In Reed $v$. Reed ${ }^{61}$ the Court struck down an Idaho law that gave men a blanket preference over women as administrators of estates. The decision was simplicity itself. There was little discussion of the appropriate standard of review. The Court observed that legislative classifications must "be reasonable, not arbitrary, and must rest on some ground of difference having a fair and substantial relation to the object of the legislation." mandatory preference to members of either sex over members of the other, merely to accomplish the elimination of hearings on the merits, is to make the very kind of arbitrary legislative choice forbidden by the Equal Protection Clause of the Fourteenth Amendment." purpose of legislation designating who should administer estates is to minimize interfamily disputes by avoiding the need for individualized judgment. This sort of legislative classification is, in its nature, arbitrary. ${ }^{64}$ Thus, the unanimous decision in Reed $v$. Reed signified that

${ }^{60}$ The new era of constitutional doctrine was preceeded by a period of intense activity and change in consciousness dimly reflected in stories in the New York Times. A series of articles from May to August 1970 reported the National Women's Strike being called for by NOW. See, e.g., N.Y. Times, May 8, 1970, at 44, col. 1; id., Aug. 27, 1970 , at 1 , col. 2 . Articles described demonstrations by women with attendance ranging from a few hundred to thousands. See, e.g., id., Aug. 27, 1970, at 1, col. $2(10,000$ people); id., Dec. 13, 1970, at 66, col. 1 (300 people). Reports of changes in school curriculum in response to the women's movement were printed. See, e.g., id., Jan. 7, 1971, at 37, col. 3 (colleges offering women's studies courses); id., Oct. 28, 1971, at 34, col. 5 (law school offering women's clinic). Articles announced new women's organizations being formed and old women's organizations reevaluating their relevance. See, e.g., id., Aug. 26, 1970, at 44, col. 3; id, July 13, 1971, at 37, col. 3. Groups of union women announcing support for equal rights and groups of women just meeting to discuss the issues were covered. See, e.g., id., Sept. 15, 1970, at 33, col. 2. One group of women psychologists demanded one million dollars in "reparations" from the American Psychological Association, claiming psychotherapy has perpetuated male supremacy and contributed to mental illness among women; the money would be used to help mentally disturbed women. See id., Sept. 6, 1970, $\S 1$, at 28, col. 1. Another small group of women seized a city-owned building to establish a health clinic and feminist school. Id., Jan. 2, 1971, at 13, col. 1. General articles on the issues being debated in the movement were also published. See, e.g., id., May 9, 1971, § 4, at 6, col. 1 (Christian theology and sex discrimination); $i d$., Oct. 10, 1971, \& 2, at 1 , col. 1 (depiction of women in films). Finally, politicians were covered as they signed orders and made proclamations. See, e.g., id., Aug. 25, 1970, at 15, col. 1. The paper reported that "women's liberation groups" charged "six years of prejudice against women" by Mayor Lindsay. See id., Aug. 24, 1971, at 11, col. 1. Two days later, Mayor Lindsay proclaimed August 26th as Women's Rights Day. Id., Aug. 26, 1971, at 8, col. 6.

61404 U.S. 71 (1971).

${ }^{62}$ Id. at 76 (citing Royster Guano Co. v. Virginia, 253 U.S. 412, 415 (1920)).

63404 U.S. at 76.

ot No one would suppose that an arbitrary preference for the children as opposed to siblings of the deceased, or vice versa, would be constitutionally infirm. Justice Holmes described such classifications, saying,

When a legal distinction is determined, as no one doubts that it may be, between night and day, childhood and maturity, or any other extremes, a 
classifications based on sex would be treated less deferentially by reviewing courts, but it failed to explain why or how. ${ }^{\mathbf{6 5}}$

Another major development in relation to sex-based equality came in 1971. The United States Congress held hearings on the Equal Rights Amendment (ERA), which was submitted to the states for ratification in $1972 .{ }^{66}$ A centerpiece of the ratification hearings was a Yale Law Journal article, written by several young feminist legal scholars and Thomas Emerson, perhaps the nation's leading scholar of constitutional civil rights and liberties. ${ }^{67}$ This article was intended to provide an interpretative guide to the meaning of the proposed ERA, and it was widely regarded as such, both in the Senate debate and in the subsequent ratification debates in the states. ${ }^{68}$ The Yale ERA article estab-

point has to be fixed or a line has to be drawn, or gradually picked out by successive decisions, to mark where the change takes place. Looked at by itself without regard to the necessity behind it the line or point seems arbitrary. It might as well or nearly as well be a little more to one side or the other. But when it is seen that a line or point there must be, and that there is no mathematical or logical ways of fixing it precisely, the decision of the legislature must be accepted unless we can say that it is very wide of any reasonable mark.

Louisville Gas Co. v. Coleman, 277 U.S. 32, 41 (1928) (Holmes, J., dissenting).

os See generally B. Babcock, Sex Discrimination, supra note 9.

${ }^{68}$ S. REP. No. 689, 92d Cong., 2d Sess. 2 (1972); H.R. REP. No. 359, 92d Cong., lst Sess. (1971). For congressional hearings in 1970-72, see Equal Rights 1970: Hearings on S.J. Res. 61 and S.J. Res. 231 Before the Senate Comm. on the Judiciary, 91st Cong., 2d Sess. (1970); The "Equal Rights" Amendment: Hearings on S.J. Res. 61 Before the Subcomm. on Constitutional Amendments of the Senate Comm. on the Judiciary, 91st Cong., 2d Sess. (1970); Equal Rights for Men and Women 1971: Hearings on H.J. Res. 35, 208 and Related Bills \& H.R. 916 and Related Bills Before Subcomm. No. 4 of the House Comm. on the Judiciary, 92d Cong., 1st Sess. (1971).

67 Brown, ERA Article, supra note 19.

68 The Yale ERA analysis, as presented to the Congress by Professor Thomas Emerson, was cited with approval by the congressional reports accompanying the proposed amendment. See S. REP. No. 689, 92d Cong., 2d Sess. 11 (1972); Separate Views Section of the House Report, H.R. ReP. No. 359, 92d Cong., 2d Sess. 6 (1971); 117 Cong. REC. H. 35,797-98 (1971). The article was praised by the principal proponents of the ERA. Congresswoman Griffiths sent a copy of it to all members of the House, saying, "It will help you understand the purposes and effects of the Equal Rights Amendment. The article explains how the ERA will work in most areas of the law." 118 CoNG. REC. 9083 (1972). Senator Bayh inserted a copy of the article in the Congressional Record, describing it as a "masterly piece of scholarship." 117 ConG. REC. 35,012 (1971). Senator Sam Ervin, a leading opponent of the amendment, stated, "I agree that the Yale Law Journal article shows at a very minimum what the ERA will accomplish." 118 CoNG. REC. 9103 (1972). For a general discussion of the Congressional debates, see Note, The Equal Rights Amendment and the Military, 82 Yale L.J. 1533, 1534-38 (1973); Note, The Sexual Segregation of American Prisons, 82 YALE L.J. 1229, 1253-60 (1973).

Despite his general endorsement of the Yale ERA article, Senator Bayh, one of the most vigorous proponents of the amendment, waffled somewhat on the question whether women would be sent to combat on a strictly equal basis, saying that "the Commander would not need to send a woman into the front trenches if he felt that it 
lished as the "basic principle" of the amendment that "sex is not a permissible factor in determining the legal rights of women, or of men. ... In short, sex is a prohibited classification." ${ }^{\text {". Th }}$ The article also concluded, however, that the ERA would not prohibit all legislative distinctions between the sexes: The authors wrote that the fundamental legal principle underlying the ERA "does not preclude legislation (or other official action) which regulates, takes into account, or otherwise deals with a physical characteristic unique to one sex. . . . This subsidiary principle is limited to physical characteristics . . . ."70

The article argued that laws regulating these physical characteristics should be scrutinized by courts in the same way that sex-neutral rules that have a disparate impact on women would be scrutinized. ${ }^{\mathbf{7 1}}$ The authors contended that the ERA would prohibit both such laws when they served as a subterfuge for sex-based discrimination, ${ }^{72}$ but they did not advocate any independent principle for laws regulating physical characteristics unique to one sex. ${ }^{73}$ Most interestingly, the ar-

would not be in the best interests of the combat unit to make such an assignment." 118 ConG. REC. S.9332 (daily ed. Mar. 21, 1972) (statement supporting military service for women).

69 Brown, ERA Article, supra note 19, at 889.

${ }^{70} I d$. at 889,893 .

71 Id. at 898-99; see id. at 895-96.

72 The primary example of a subterfuge for sex-based discrimination, presented in the section headed, "Laws Dealing with Physical Characteristics Unique to One Sex," is "a government regulation to reduce absenteeism at policy-making levels by barring women from certain jobs." Id. at 894 . The article then suggests five criteria by which we could determine whether such a law was in fact one relating to a unique physical characteristic or whether it was rather a subterfuge for sex discrimination: the proportion of women who have the characteristic; the relation between the characteristic and the problem; "the proportion of the problem attributable to the unique physical characteristic of women"; "the proportion of the problem eliminated by the solution"; "the availability of less drastic alternatives." Id. at 895-96. A law barring all women from certain jobs is not one "dealing with physical characteristics unique to one sex." It is explicit sex discrimination. See infra notes 200-15 and accompanying text.

${ }_{73}$ See also Note, Sex Discrimination and Equal Protection: Do We Need a Constitutional Amendment?, 84 HARv. L. REv. 1499 (1971). After exploring the similarities between race- and sex-based discrimination, this analysis addressed the limits of the race/sex analogy:

[W]omen may differ from men in ways which might rationally be reflected in statutes. For example, women appear to live longer on the average and exclusively possess the procreative function. Some alleged differences may turn out, on further investigation, to be products of environment and training rather than of immutable physiology. Until further studies are made, however, the possibility that the apparent differences are real must be acknowledged. Laws classifying on the basis of such apparent differences between the sexes might be upheld ....

Id. at 1508-09 (footnotes omitted). This is the whole of the discussion of the myth and reality of biological difference in a 25-page analysis of sex discrimination. It does not recognize that the procreative function may distinguish men and women in a way that is categorically different than statistical differences in longevity. It is hard to see how 
ticle's discussion and application of its test to regulations of physical characteristics made no mention of laws restricting access to abortions. Nor did the article mention laws excluding pregnant women from health insurance programs. These two omissions are especially striking because abortion rights and pregnancy benefits are much more central to the goal of sex equality than the examples discussed in the article, such as laws that regulate wet nurses, sperm donors, medical leave for childbearing, and determination of fatherhood. ${ }^{74}$

A third significant development occurred during the 1971 Supreme Court term, four months after Reed. In Eisenstadt v. Baird, ${ }^{76}$ the Court struck down a Massachusetts law prohibiting the distribution of contraceptives, except by doctors to married people, on grounds that the distinction between married and unmarried people violated equal protection. Eisenstadt is a difficult case. ${ }^{76}$ To this day, the criminal law in many states prohibits sex between unmarried people, and the Court has not disapproved this distinction between the married and the unmarried. ${ }^{77}$ Sex-based equality could have provided a stronger basis for the

further investigation is likely to disprove this categorical difference or tell us how to regard it.

24 See Brown, ERA Article, supra note 19, at 894.

73405 U.S. 438 (1971).

${ }^{78}$ Both the Court and commentators have subsequently read Eisenstadt as a decision resting on the right to privacy or the due process concept of fundamental fairness. A Lexis search in March 1984 reveals that Eisenstadt has been cited by the Supreme Court 40 times. Five of those cites were on the standing issue. Seven cites were for general discussion of the type of analysis to be used for equal protection claims. The remaining 28 cases cited Eisenstadt in connection with the right to privacy recognized in Griswold.

Two of the equal protection cases citing Eisenstadt involved claims of sex discrimination. Both Weinberger v. Wiesenfeld, 420 U.S. 636 (1975), and Schlesinger v. Ballard, 419 U.S. 498 (1975) (Brennan, J., dissenting), cite the case for the proposition that the court need not "accept at face value assertions of legislative purposes." Weinberger, 420 U.S. at 648. See Schlesinger, 419 U.S. at 520.

Some commentators, writing immediately following Eisenstadt, analyzed it as an equal protection case. See, e.g., The Supreme Court 1971 Term, 86 Harv. L. REv. 52, 116 (1972). More recently it has been cited as a privacy case. See, e.g., Brest, The Fundamental Rights Controversy: The Essential Contradictions of Normative Constitutional Scholarship, 90 YALE L.J. 1063, 1064 (1981). At least one commentator has discussed the case as both a privacy and an equal protection case. See Karst, The Freedom of Intimate Association, 89 YALE L.J. 624, 641, 662-63 (1980).

Although the result in Griswold supported recognition of a constitutionally protected right to personal autonomy in relation to the decision whether or not to bear or beget a child, the specific holding of Griswold was narrower. Griswold invalidated only that portion of Connecticut's statute that banned "use" of contraceptives by married people and was closely tied to the physical privacy of the bedroom, a privacy interest arguably protected by the fourth amendment, as well as the more porous concepts of due process and the ninth amendment. See Ely, The Wages of Crying Wolf: A Comment on Roe v. Wade, 82 Yale L.J. 920, 928-30 (1973).

77 In Michael M. v. Superior Court, 450 U.S. 464 (1981), Justice Stevens stated, "I would have no doubt about the validity of a state law prohibiting all unmarried 
decision in Eisenstadt. The differential burden that denying access to contraceptives imposes upon women is not a facially neutral policy having a disparate impact upon different groups of people ${ }^{78}$ - no man faces the physical risks of pregnancy. Even assuming that both parents bear equal responsibility for the child after birth, only women are confronted with the choice of obtaining an abortion or enduring the physical burdens of pregnancy. A more forceful decision in Eisenstadt, based on the sex equality principle, could have accepted the legitimacy of the state interest in discouraging sex outside of marriage, yet still concluded that, despite this interest, denying women access to contraception "prescribes pregnancy and the birth of an unwanted child as punishment for fornication." The unwanted pregnancy is not simply a burden women must, in the nature of things, bear. Where the state denies access to contraception, it is a burden the state imposes. ${ }^{80}$

teenagers from engaging in sexual intercourse." Id. at 497 (Stevens, J., dissenting).

${ }_{78}$ See Personnel Adm'r v. Feeney, 442 U.S. 256 (1979); Washington v. Davis, 426 U.S. 229 (1976).

${ }^{70}$ In Eisenstadt the Court found that "[i]t would be plainly unreasonable to assume that Massachusetts has prescribed pregnancy and the birth of an unwanted child as punishment for fornication, which is a misdemeanor under Massachusetts [law]." 405 U.S. at 448. This assumption and a finding that it was not reasonable to characterize the law as a health measure were preludes to finding that the purpose of the law was simply to restrict access to contraception.

The theme that imposing unwanted pregnancy as punishment for prohibited sex is a violation of due process fairness was adopted by Justice Stevens's concurring opinion in Carey v. Population Serv. International, 431 U.S. 678 (1977) (invalidating statute prohibiting sale or distribution to minors and prohibiting display of contraceptives:

Although the State may properly perform a teaching function, it seems to me that an attempt to persuade by inflicting harm on the listener is an unacceptable means of conveying a message that is otherwise legitimate. The propaganda technique used in this case significantly increases the risk of unwanted pregnancy and venereal disease. It is as though a State decided to dramatize its disapproval of motorcycles by forbidding the use of safety helmets. One need not posit a constitutional right to ride a motorcycle to characterize such a restriction as irrational and perverse.

Even as a regulation of behavior, such a statute would be defective. Assuming that the State could impose a uniform sanction upon young persons who risk self-inflicted harm by operating motorcycles, or by engaging in sexual activity, surely that sanction could not take the form of deliberately injuring the cyclist or infecting the promiscuous child. If such punishment may not be administered deliberately, after trial and a finding of guilt, it manifestly cannot be imposed by a legislature, indiscriminately and at random. This kind of government-mandated harm, is, in my judgment, appropriately characterized as a deprivation of liberty without due process of law.

Id. at 715-16 (Stevens, J., concurring) (emphasis added).

${ }^{80}$ The sex differential nature of the law is confirmed by examination of the state purpose asserted to justify it. The ideal of chastity and moral virtue that Massachusetts sought to promote was the ideal of the sexual double standard, which demanded chastity principally of women. See supra note 19. The Massachusetts court, in construing the 
Despite the strength of these sex discrimination arguments, they were not advanced in Eisenstadt for perfectly understandable reasons. ${ }^{\mathbf{8 1}}$ Eisenstadt was argued on November 17, 1971. Reed was decided five days later. Although sex equality was in the public consciousness, ${ }^{\mathbf{8 2}} \mathrm{Su}-$ preme Court cases provided no support for an assertion that equality had anything to do with women.

The possibility of greater judicial sensitivity to issues of sex equality was, however, suggested by the Court's decision in Reed. Two years later, ACLU counsel Ruth Bader Ginsburg urged, in Frontiero $v$. Richardson, ${ }^{83}$ that the Court's scrutiny of sex-based classifications be formalized and that such classifications, like those based on race, be treated as constitutionally suspect. The task confronting the appellants in Frontiero was formidable. At that time, the prevailing constitutional law still included Bradwell v. Illinois, ${ }^{84}$ Muller v. Oregon, ${ }^{85}$ Goesaert v. Cleary, ${ }^{88}$ and Hoyt $v$. Florida. ${ }^{87}$ The ACLU brief discussed these cases under the consummately understated banner, "Precedent in Need of Reevaluation."88 The argument urging that sex-based classifications be treated as constitutionally suspect incorporated three themes. First, historically women have been subjugated, their essential humanity denied, and the pedestal upon which they have been placed has all too often been a cage. Second, women seek to be judged on their individual merits; the stereotypes of married women as economically dependent

law prohibiting the distribution of contraceptives to unmarried people, found that its purpose was "to protect purity, to preserve chastity, to encourage continence and selfrestraint, to defend the sanctity of the home and thus to engender . . . a virile and virtuous race of men and women." Commonwealth v. Allison, 227 Mass. 57, 62, 116 N.E. 265, 266 (1917), quoted in Eisenstadt, 405 U.S. at 448. However, the Massachusetts law allowed distribution of condoms, for use in preventing venereal disease. Citing the circuit court opinion, the Supreme Court noted, "It is 200 years since Casanova recorded the ubiquitous article. . . . We cannot think the legislature was unaware of it, or could have thought it needed a medical prescription." 405 U.S. at 451 n.9. The Court observed that the medical risks associated with the vaginal foam distributed to women had not been proved to be greater than the medical risks associated with condoms. See id. at 464 (White, J., concurring). The Court, however, did not focus on the fact that that only those safe forms of contraception used and controlled by women were prohibited, while those used and controlled by men were allowed.

82 An amicus curiae brief was filed in Eisenstadt by Human Rights for Women, Inc. and argued that denying access to contraception has a disproportionate effect upon women.

82 See supra note 60.

83411 U.S. 677 (1973).

83 U.S. (16 Wall.) 130 (1872).

85 208 U.S. 412 (1908).

86 335 U.S. 464 (1948).

87368 U.S. 57 (1961).

88 Amicus Curiae Brief of American Civil Liberties Union at 34, Frontiero v. Richardson, 411 U.S. 677 (1973). 
are inaccurate generally and particularly as applied to the Frontieros. And third, sex is an immutable characteristic that frequently bears no relation to ability to perform or contribute. ${ }^{89}$ Historical oppression, the value of individuality, and the presumptive inaccuracy of sex-based stereotypes all supported vigorous scrutiny of sex-based classifications.

Like the Yale ERA article, the ACLU brief in Frontiero did not focus on the reality of biological difference. It mentioned biological difference only once, stating that legislative "discrimination grounded on sex, for purposes unrelated to any biological difference between the sexes, ranks with legislative discrimination based on race." ure to address the issue of biological difference is justifiable in relation to the specific claim presented by Sharon Frontiero, who was challenging a law that required that male spouses-but not female spouses-be actually dependent, in order to receive military benefits. Biological differences had no relation to the sex discriminatory military pay policy at issue in the case. ${ }^{91}$ But if the Frontiero briefs are examined not simply as an individual family's challenge to a sex discriminatory pay policy but as an attempt to articulate a coherent scheme for addressing issues of sex equality, the failure to address in any detail the relation between equality and biological difference is puzzling. It is also troubling that the brief's only reference to biological difference suggests that laws based on such difference may not raise equality concerns and, consequently, may not need to be scrutinized as carefully.

In Frontiero, four Justices ruled that sex-based classifications should be regarded as constitutionally suspect. ${ }^{92}$ Four Justices concurred in the result but thought it sufficient to invalidate the classification as unreasonable, without addressing the general issue of the appropriate constitutional standard for judging sex-based classifications. ${ }^{\mathbf{}}{ }^{3}$

On January 23, 1973, just after the argument in Frontiero, the Court held in Roe $v$. Wade $e^{\mathbf{9 4}}$ that the constitutional right to privacy protects the right of women and their physicians to determine whether

${ }^{88} I d$. at $24-28$.

$90 \mathrm{Id}$. at 7.

91 The irrelevance of biology did not prevent the government from invoking biology to justify the pay discrimination and arguing that "sex classifications are commonly founded upon physiological and sociological differences." Brief for Appellees at 17, Frontiero v. Richardson, 411 U.S. 677 (1973). The government's brief described laws prohibiting women from tending bar as "based on objective differences between the sexes." Id.

82411 U.S. at $682-91$.

9s $I d$. at 691 . The concurring opinion also cited the pendency of the proposed ERA as a reason for avoiding decision on the standard applicable under the fourteenth amendment. See id. at 692 (Powell, J., concurring).

or 410 U.S. 113 (1973). 
or not to terminate pregnancy ${ }^{95}$ Nothing the Supreme Court has ever done has been more concretely important for women. ${ }^{96}$ Laws denying access to abortion have a sex-specific impact. Although both men and women seek to control reproduction, only women become pregnant. Only women have abortions. Laws restricting access to abortion have a devastating sex-specific impact. Despite the decision's overwhelming importance to women, it was not grounded on the principle of sex equality. The plaintiffs in Roe v. Wade and Doe v. Bolton ${ }^{97}$ had not challenged the abortion restrictions as sex discriminatory, ${ }^{98}$ and the Supreme Court did not rely upon the sex-specific impact of laws restricting access to abortion. ${ }^{99}$

Thus, during the early 1970's the constitutional rights of women began to be recognized by the Supreme Court, but several forces encouraged the Court to avoid addressing the relationship between sexbased equality and biological differences. First, those primarily responsible for developing a constitutional doctrine of sex-based equality, including the ACLU and the proponents of the ERA, adopted what amounted to an assimilationist vision of sex equality, which minimized the significance of biological differences. Second, many who worked to develop constitutional doctrine to support reproductive freedom emphasized rights of privacy, physician discretion, and the vagueness and uncertainty of the criminal laws prohibiting abortions. The decision to deemphasize sex discrimination in the reproductive freedom cases re-

93 Id. at 154.

98 I would defend this statement by comparing other decisions that possibly come close to Roe $v$. Wade in importance to women, but I cannot think of anything that is arguably a close second.

${ }^{\circ 7} 410$ U.S. 179 (1973).

98 The Texas statute challenged in Roe v. Wade, 410 U.S. 113 (1973), made abortions illegal unless performed to save the life of the mother. The plaintiffs in Roe argued that a person's right to care for one's own health and a constitutional right to privacy were being unduly burdened by the statute. The plaintiffs also asserted a physician's right to administer health care without arbitrary interference from the state. See Roe, 410 U.S. at 120-22.

The Georgia statute challenged in Doe v. Bolton allowed abortions only when the pregnancy threatened the life or health of the mother, the fetus would be born deformed, or the pregnancy resulted from rape. The statute also required three doctors' certifications and approval by a hospital committee, and it prohibited abortions performed outside an accredited hospital. The plaintiffs in Doe argued that the statute abridged a fundamental right to privacy and a physician's right to practice medicine and that it was unconstitutionally vague. Plaintiffs also claimed that the woman was denied due process by a procedure so cumbersome and time consuming as to "effectively manipulate out of existence plaintiff's constitutional rights." Finally plaintiffs argued that the statute discriminated against the "poor and Negro citizens, denying them equal protection." Brief for Appellants at ii, iii, Doe v. Bolton, 410 U.S. 179 (1973).

See the criticism infra notes 231-34. 
flected a judgment that privacy was a more conservative and, hence, stronger constitutional tool than sex-based equality.

In cases challenging laws governing pregnant women it is particularly difficult to avoid addressing the relationship between sex-based equality and biological difference. In the 1972 and 1973 Terms the Supreme Court was presented with three such cases. In each lawyers for the pregnant women argued that courts should scrutinize legislation adversely affecting pregnant women in the same way that they scrutinize laws incorporating explicit sex-based classifications. ${ }^{100}$

Struck $v$. Secretary of Defense ${ }^{101}$ presented the Court with a constitutional challenge to an Air Force policy requiring the discharge of pregnant officers. The Court remanded the case on grounds of mootness $^{102}$ and therefore avoided review on the merits of the policy.

Pregnant women in Cleveland Board of Education v. LaFleur ${ }^{103}$ challenged a mandatory leave policy that required pregnant teachers to go on unpaid maternity leave five months before the expected birth date of the child and that prevented a teacher's return to work until the child was at least three months old. Even though the policy was challenged as sex discriminatory and the Fourth Circuit decided the case on that ground, ${ }^{104}$ the Supreme Court avoided any discussion of the discriminatory nature of the classification by striking down the policy because it "employ[ed] irrebuttable presumptions."105

Having thus avoided the sex discrimination claims of pregnant

100 The ACLU brief in Struck v. Secretary of Defense, 409 U.S. 1071 (1972), argued that "sex discrimination exists when all or a defined class of women (or men) are subjected to disadvantaged treatment based on stereotypical assumptions that operate to foreclose opportunity based on individual merit." The ACLU urged that the pregnancy regulations "should be subject to close scrutiny, identifying sex as a suspect criteria for governmental distinctions." Brief for the Petitioner at 15, 26, Struck v. Secretary of Defense, 409 U.S. 1071 (1972). See also Brief for Appellees at 28, Geduldig v. Aiello, 417 U.S. 484 (1974); Brief for Respondents on Writ of Certiorari to the United States Court of Appeals for the Sixth Circuit at 18, Gleveland Bd. of Educ. v. LaFleur, 414 U.S. 632 (1974).

101460 F.2d 1372 (9th Cir.), vacated and remanded, 409 U.S. 1071 (1972).

102 The Air Force voluntarily abandoned its policy after it prevailed in the district court. The Supreme Court rejected the ACLU's argument that the constitutional claim was not thus made moot. See 409 U.S. at 1071.

103414 U.S. 632 (1974).

104474 F.2d 395 (4th Gir. 1973).

108414 U.S. at 648 . The doctrine of unconstitutional presumptions employed by the Court in LaFleur is often invoked to avoid analysis of a difficult alternative constitutional claim. See, e.g., Berzanson, Some Thoughts on the Emerging Irrebuttable Presumption Doctrine, 7 IND. L. REv. 644 (1974); Note, The Irrebuttable Presumption Doctrine in the Supreme Court, 87 Harv. L. REv. 1534 (1974); cf. Weinberger v. Salfi, 422 U.S. 749 (1975). Justice Rehnquist, dissenting in LaFleur, characterized the irrebuttable presumption doctrine as "nothing less than an attack upon the very notion of lawmaking itself." 414 U.S. at 660. 
women who were ready and able to work but barred from doing so, the Court in Geduldig $v$. Aiello ${ }^{108}$ finally addressed sex equality claims of pregnant women in 1974, holding that discrimination against pregnant people is not sex-based.

Criticizing Geduldig has since become a cottage industry. Over two dozen law review articles have condemned both the Court's approach and the result. ${ }^{107}$ In addition, other general analyses of constitutional doctrine intlude denunciations of the decision. ${ }^{108}$ Even the princi-

108417 U.S. 484 (1974).

${ }^{107}$ Erickson, Equality Between the Sexes in the 1980's, 28 CLEv. ST. L. REv. 591 (1979); Fain, Pregnancy and Sex Discrimination, 5 Tex. So. U.L. Rev. 54 (1978); Ferrell, The Equal Rights Amendment to the United States Constitution-Areas of Controversy, 6 URB. LAw. 853 (1974); Ginsberg, Gender in the Supreme Court; the 1973 and 1974 Terns, 1975 Sup. CT. Rev. 1; Ginsberg, Gender and the Constitution, 44 U. GIN. L. REv. 1 (1975); Johnston, Sex Discrimination and the Supreme Court-1971-1974, 49 N.Y.U. L. REv. 617 (1974); Kirp \& Robyn, Pregnancy, Justice, and the Justices, 57 TEx. L. REv. 947 (1979); Larson, Sex Discrimination as to Maternity Benefits, 1975 Duke L.J. 805; Peratis \& Rindskopf, Pregnancy Discrimination as a Sex Discrimination Issue, 2 Women's RTs. Law REP. 26 (1975); Scales, supra note 7; Weynand, Bearing the Cost of Bearing, 11 TRIaL 86 (1975); Comment, Pregnancy Disability Benefits and Title VII: Pregnancy Does Not Involve Sex?, 29 Baylor L. Rev. 257 (1977); Comment, Pregnancy and Employment Benefits, 27 BAylor L. Rev. 767 (1975); Note, Constitutional Law-Equal Protection-Discrimination Against Pregnancy Is Not Sex Discrimination-Geduldig v. Aiello, 1975 B.Y.U. L. REv. 171; Comment, Pregnancy and the Constitution: The Uniqueness Trap, 62 CALIF. L. REv. 1532 (1974); Comment, Pregnancy Disability Benefits Under State Administered Insurance Programs, 24 Gath. U.L. REv. 263 (1975); Comment, General Electric Co. v. Gilbert: Defining the Equal Opportunity Rights of Pregnant Workers, 10 Colum. Hum. RTs. L. Rev. 605 (1978-79); Comment, Geduldig v. Aiello: Pregnancy Classifications and the Definition of Sex Discrimination, 75 Colum. L. REv. 441 (1975); Comment, Current Trends in Pregnancy Benefits-1972 EEOC Guidelines Interpreted, 24 DE PAUL L. REv. 127 (1974); Note, Title VII, Pregnancy, and Disability Payments: Women and Children Last, 44 Geo. Wash. L. Rev. 381 (1976); Comment, Three Cases Against Motherhood, 2 Glendale L. REv. 313 (1977); Note, Exclusion of Pregnancy from Coverage of Disability Benefits Does Not Violate Equal Protection, 12 Hous. L. REv. 488 (1975); Note, The Impact of Geduldig v. Aiello on the EEOC Guidelines on Sex Discrimination, 50 IND. L.J. 592 (1975); Comment, The 1978 Amendment to Title VII: The Legislative Reaction to the Geduldig-Gilbert-Satty Pregnancy Exclusion Problem in Disability Benefit Programs, 27 Loy. L. Rev. 532 (1981); Comment, Barefoot and Pregnant-Still: Equal Protection for Women in Light of Geduldig v. Aiello, 16 S. TEx. L.J. 211 (1975); Comment, The Supreme Court 1974 Term and Sex-Based Classifications: Avoiding a Standard of Review, 19 ST. Louts U.L.J. 375 (1975); Comment, Sex Discrimination in the 1970's: the Supreme Court Decisions, 6 TEx. TECH. L. REv. 149 (1974); Note, Pregnancy and Sex-Based Discrimination in Employment: A Post-Aiello Analysis, 44 U. CrN. L. REv. 57 (1975); Note, Pregnancy Disability Benefits Denied: Narrowing the Scope of Title VII, 32 U. MIAMI L. REv. 173 (1977); Recent Developments, Geduldig v. Aiello, 3 Hofstra L. REv. 141 (1975); Gase Note, Constitutional Law-Equal Protection-Under a Compulsory Unemploynent Disability Insurance System, a State May Permissibly Exclude from Coverage Disability Resulting from Normal Pregnancy, 52 J. URB. LAW 591 (1974).

108 L. TRIBE, AMERICaN Constitutional Law § 16-27 (1978); Karst, The Supreme Court 1976 Term-Foreword: Equal Citizenship Under the Fourteenth Amend- 
pal scholarly defense of Geduldig admits that the Court was wrong in refusing to recognize that the classification was sex-based, but it argues that the Court was correct in holding the classification reasonable. ${ }^{109}$ The Court has not often relied upon the case and has held, in puzzling terms, that discrimination against pregnant women is sometimes sexbased. ${ }^{110}$ Congress, responding to another Court decision that followed the reasoning in Geduldig, ${ }^{111}$ has made plain that Title VII's prohibition of sex discrimination bars discrimination on the basis of pregnancy. ${ }^{112}$

ment, 91 HARv. L. REv. 1, 54 (1977).

109 See Rutherglen, Sexual Equality in Fringe-Benefit Plans, 65 VA. L. REv. 199 (1979); Schair, Sex Discrimination: The Pregnancy-Related Disability Exclusion, 49 ST. JoHn's L. REv. 684 (1975). Mendelson, in ERA, the Supreme Court, and Allegations of Gender Bias, 44 Mo. L. REv. 1, 8 (1979), argues that "apart from rape, pregnancy is always willful as compared to a heart attack" and thus may be treated disfavorably.

110 A Lexis search in April 1984 revealed that Geduldig $v$. Aiello has been cited by the Supreme Court in 10 cases. The earliest case citing Geduldig used it in a string cite for the proposition that the Court need not decide if sex is a suspect class. See Stanton v. Stanton, 421 U.S. 7, 13 (1975). Five cases cited Geduldig for general equal protection arguments regarding insurance programs. The Court specifically limited Geduldig to questions involving insurance in Turner v. Dep't of Employment Sec., 423 U.S. 44, 45 (1975), where the Court found Geduldig did not control.

In General Electric Company v. Gilbert, 429 U.S. 125 (1976), the Court applied Geduldig's equal protection analysis to Title VII claims. Two later Title VII cases distinguish General Electric. Nashville Gas Co. v. Satty, 434 U.S. 136 (1977), held that "petitioner has not merely refused to extend to women a benefit that men cannot and do not receive, but has imposed on women a substantial burden that men need not suffer. The distinction between benefits and burdens is more than one of semantics." 434 U.S. at 142. Gity of Los Angeles Dep't of Water and Power v. Manhart, 435 U.S. 702 (1978), condemned the use of sex-based actuarial tables, holding that "each of the two groups of employees involved in this case is composed entirely and exclusively of members of the same sex," unlike Gilbert and Geduldig where the two groups were "pregnant women and nonpregnant persons." 435 U.S. at 715 . The most recent Supreme Court case citing Geduldig made clear that not only had the Court rejected both Geduldig and Gilbert, but also that Congress had rejected those holdings by enacting the Pregnancy Disability Act (discussed infra note 94). See Newport News Shipbldg. \& Dry Dock Co. v. EEOG, 103 S. Ct. 2622 (1983).

111 General Electric Co. v. Gilbert, 429 U.S. 125 (1976).

112 After the Court extended the "logic" of Geduldig to Title VII, Congress reacted swiftly to provide in the Pregnancy Discrimination Act (PDA) of 1978 that "the terms 'because of sex' or 'on the basis of sex' include, but are not limited to, because of or on the basis of pregnancy, childbirth, or related medical conditions." 42 U.S.C. $\S$ $2000 \mathrm{e}(\mathrm{k})$ (Supp. V 1981). The thrust of the PDA is to require that pregnancy, childbirth, and other related medical conditions be treated as well as any other medical disability, not unique to one sex. See Erickson, Pregnancy Discrimination: An Analytic Approach, 7 Women's RTS. L. REP. 11 (1981); Scales, supra note 7 at 401-15.

Newport News Shipbldg. \& Dry Dock Co. v. EEOC, 103 S. Ct. 2622 (1983), applied the PDA to invalidate an employer benefit program providing full medical coverage for employees and their spouses but limiting maternity benefits for the wives of male employees. The Court held,

The Pregnancy Discrimination Act has now made clear that, for all Title 
Doctrinally, however, Geduldig has made it more difficult to claim that reproductive freedom is an aspect of sex-based equality. If discrimination against pregnant women is not sex-based when the woman seeks to carry her pregnancy to term, it is hard to argue that it is sexbased for the state to create obstacles to abortion. ${ }^{113}$ Since 1973, literally hundreds of legal challenges to restrictive abortion laws have been brought, ${ }^{114}$ and only a very few of the cases have argued that the restrictions violated sex equality norms. ${ }^{115}$

VII purposes, discrimination based on a woman's pregnancy is, on its face, discrimination because of her sex. And since the sex of the spouse is always the opposite of the sex of the employee, it follows inexorably that discrimination against female spouses in the provision of fringe benefits is also discrimination against male employees.

\section{Id. at 2631 .}

Although the PDA significantly limits the practical effect of the Supreme Court's holding that discrimination on the basis of pregnancy is not sex-based, it does not affect the general constitutional principle. Congress cannot overrule the Court's interpretation of the Constitution. Estreicher, Congressional Power and Constitutional Rights: Reflections on Proposed 'Human Life' Legislation, 68 VA. L. REv. 333 (1982). Further, the PDA is explicitly limited to defining discrimination on the basis of pregnancy and childbirth as sex based and does not more broadly define all discrimination on the basis of sex-specific physical characteristics as sex based. The PDA explicitly provides that it "shall not require an employer to pay for health insurance benefits for abortion, except where the life of the mother would be endangered if the fetus were carried to term, or except where medical complications have arisen from an abortion . . .."

11 However, the Court has recognized that "penalizing" forms of discrimination against pregnant women are indeed sex based. See Nashville Gas Co. v. Satty, 434 U.S. 136 (1977); Turner v. Dep't of Employment Sec., 423 U.S. 44 (1975). It is arguable that forcing a woman to bear a child penalizes her.

${ }_{114}$ See generally Legal Docket, ACLU Reproductive Freedom Project. The national ACLU's Reproductive Freedom Project discouraged sex discrimination claims in cases challenging restrictions on reproductive freedom.

116 Equality claims have been raised in a few lower courts. On January 18, 1978, Hawaii Right to Life filed suit to enjoin the state of Hawail from funding Medicaid abortions. The local ACLU, representing several gynecologists practicing in Hawaii, moved to intervene. One claim made by the local groups was that funding for Medicaid abortions was required by the state equal rights amendment. See Motion to Intervene, Hawaii Right to Life v. Chang, Civil No. 53567 (Feb. 20, 1979). This was the first time a state ERA was used to defend abortion rights. The motion to intervene was denied; the case was later decided by summary judgment in favor of the state funding policy. See Hawaii Right to Life v. Ghang, Givil No. 53567 (Feb. 20, 1979) (order granting summary judgment). A similar sex discrimination claim was raised under the Massachusetts ERA. See Moe v. Secretary of Admin. \& Fin., 382 Mass. 629, 417 N.E.2d 387 (1981).

Right to Life News describes these cases, pointing out that "[t]he proposed federal ERA has the same language" as the state ERA and expressing concern that if the ERA claims were successful, "the argument could prove persuasive to judges in other states that have ERA in their Constitution." $A C L U$ Tells Massachusetts Court That State ERA Mandates Medicaid Abortion Funding, Right to Life News, July 21, 1980, at 1; Britt, In Hawaii Abortionists Cite ERA as Support, Right to Life News, Jan. 1979, at 9.

Fischer v. Dep't of Pub. Welfare, No. 283 C.D. 1981 (Pa. Commw. Ct. Mar. 9, 1984), reh'g granted en banc, argued May 1, 1984. held that excluding abortion ser- 
However, doctrine is not the only reason why sex equality claims have not been asserted in defense of women's abortion rights. Over the years following Roe v. Wade, women's struggle for control of their bodies has been transformed into debates about medical practice and moral and religious views of the personhood of the fetus. ${ }^{116}$ In the abortion debate, women's lives and sex-based equality have become distinctly secondary issues. The decision in Roe $v$. Wade established the Court as a single, highly visible target for opponents of abortion. By raising issues of institutional competence, the decision also provided a basis of opposition to abortion distinct from the merits of reproductive freedom itself. ${ }^{117}$

Abortion is politically controversial, probably much more so than any other sex equality issue. The ERA, as proposed to the states by the

vices from the otherwise comprehensive Medicaid program violated the equal protection guarantee of the state constitution. Several other state courts have reached the same conclusion. In addition the Pennsylvania court held that the exclusion violated the state ERA.

In Anderson v. Upper Bucks County Area Vocational Technical School, 30 Pa. Commonwealth Ct. 103, 110, 373 A.2d 126, 130 (1977), this Court held that "since pregnancy is unique to women, a disability plan which expressly denies benefits for disability arising out of pregnancy is one which discriminates against women employees because of their sex."...

The Commonwealth argues to us that the indigent women in need of medically necessary abortions would be in equally bad circumstances if there were no Medical Assistance program. That argument misses the mark. There is a Medical Assistance program and once the legislature has decided to grant financial assistance to the medically needy, it cannot exclude persons from that grant on the basis of sex. . . .

We are of the opinion that while Petitioners' argument under the ERA is not as strong as their equal protection argument, it is meritorious and sufficient in and of itself to invalidate the statutes before us in that those statutes do unlawfully discriminate against women with respect to a physical condition unique to women.

Id., slip op. at 19-21.

Abortion opponents have also argued that adoption of a federal ERA would mandate Medicaid funding for abortion. The proponents of the federal ERA reject this claim. Whether a federal ERA affects abortion depends upon the intentions of the amendment's proponents, as reflected in the legislative history. See infra note 29.

A sex equality claim in an abortion case was first presented to the Supreme Court in Motion for Leave to File Brief Amici Curiae and Annexed Brief of the Committee for Abortion Rights and Against Sterilization Abuse and Others at 4-16, City of Akron v. Akron Center for Reproductive Health, Inc., 103 S. Ct. 2481 (1983).

${ }^{116}$ See, e.g., F. Jaffe, B. Lindheim, \& P. LeE, Abortion Politics (1981).

${ }_{117}$ See, e.g., City of Akron v. Akron Center for Reproductive Health, 103 S. Ct. 2481, 2511-12 (1983) (O'Connor, J., dissenting); see also A. Cox, The Role of THE SUPREMe Court IN AMERICAN GOVERnMENT 113 (1976); Epstein, Substantive Due Process by Any Other Name: The Abortion Cases, 1973 SuP. CT. REv. 159; Freund, Storms over the Supreme Court, 69 A.B.A. J. 1474, 1480 (1983). 
Congress in 1971, exempted laws governing "physical characteristics, unique to one sex" from the amendment's proscription, except insofar as the ERA affected neutral rules that had an oppressive sex-specific impact. $^{118}$

To assert that the fourteenth amendment or a state ERA mandates a concept of sex equality that encompasses a woman's interest in controlling reproductive capacity would inescapably affect the effort to enact a federal ERA. ${ }^{119}$ Nevertheless, it is important to explore the political and legal separation of sex equality and reproductive freedom and to evaluate the value of a more integrated approach.

This historical overview has identified several reasons for the dichotomy between sex equality doctrine and constitutional evaluation of laws governing reproductive biology. In particular, this doctrinal failure means that notions of sex equality are irrelevant to the constitutional rights of pregnant women. The next section of this Article will discuss how the failure to develop a sex equality doctrine that is more responsive to biological difference has affected the Court's analysis in cases challenging explicit sex-based classifications.

\section{Removing Biology from SeX}

EQUALITY-AsSESSING THE EFFECT OF THE SUPREME COURT's INTERMEdIATE SCRUTINY

The Supreme Court has agreed upon "several firmly-established principles" for analyzing claims that a governmental rule discriminates on the basis of sex. ${ }^{120}$ The constitutional standard employed by the Court requires that "to withstand constitutional challenge . . . classifications by gender must serve important governmental objectives and must be substantially related to the achievement of those objectives."121 This " intermediate' scrutiny," is intended to ensure that governmental classifications are "determined through reasoned analysis rather than through the mechanical application of traditional, often inaccurate, assumptions about the proper roles

118 See Brown, ERA Article, supra note 18, at 893-96.

11 See, e.g., statement of Senator DeConcini, quoted infra note 282.

120 Mississippi Univ. for Women v. Hogan, 458 U.S. 718, 723 (1982).

121 Craig v. Boren, 429 U.S. 190, 197 (1976). The Court has also stated that "the party seeking to uphold a statute that classifies individuals on the basis of their gender must carry the burden of showing an 'exceedingly persuasive justification' for the classification." Hogan, 458 U.S. at 724 (quoting Kirchberg v. Feenstra, 450 U.S. 455, 461 (1981)).

122 Plyler v. Doe, 457 U.S. 202, 218 n.16 (1982).

123429 U.S. 190 (1976). 
of men and women."124 Such stereotyping is prohibited not only because it denies opportunities to men and women who are unwilling to conform to certain social notions of appropriate behavior, but also because, when enforced, such classifications become "a self-fulfilling prophecy."12s

But present constitutional equality doctrine does not encompass concern with laws that regulate real biological difference. This failure has undermined strong equality analysis in cases challenging explicit sex-based classifications. The Craig standard, condemning explicit sex based classifications based on inaccurate stereotypical views of men and women, collapses when applied to explicit sex-based classifications that are arguably related to real biological differences. The Supreme Court has recently considered four such cases in which men presented equal protection challenges to explicit sex-based classifications that arguably related to reproductive biology. ${ }^{126}$ Each case was decided by a sharply divided Court, and the analysis in each suffers from a failure to distinguish between biological differences and social stereotypes.

\section{A. Unmarried Fathers: Parham, Caban, and Lehr}

In Parham v. Hughes, ${ }^{127}$ Caban v. Mohammed, ${ }^{128}$ and Lehr v. Robertson, ${ }^{129}$ the Court considered the sex equality claims of unmarried fathers who challenged state laws treating them less favorably than mothers. ${ }^{190}$ In Parham the father sought to bring a tort claim for the wrongful death of his child; all mothers were allowed to assert such claims, but unmarried fathers were not. ${ }^{131}$ In Caban the father objected to the proposed adoption of his children. New York law gave mothers

124 Mississippi Univ. for Women v. Hogan, 458 U.S. 718, 726 (1982).

123 Id. at 730 .

126 Lehr v. Robertson, 103 S. Ct. 2985 (1983); Michael M. v. Superior Court, 450 U.S. 464 (1981); Caban v. Mohammed, 441 U.S. 380 (1979); Parham v. Hughes, 441 U.S. 347 (1979).

127441 U.S. 347 (1979).

128441 U.S. 380 (1979).

129103 S. Ct. 2985 (1983).

130 Stanley v. Illinois, 405 U.S. 645 (1972), also posed an equality claim on behalf of an unmarried father who challenged the state's action terminating his relationship with his children. In a move like that used to avoid the early challenges to sex-based discrimination against pregnant women, see supra note 97-105, the Court evaded the equality claim by holding that due process requires a hearing prior to termination of the parent-child relation. The state may not insist on "presuming rather than proving Stanley's unfitness solely because it is more convenient to presume than to prove." Id. at 658 .

131 Under Georgia law a father was allowed to sue for the wrongful death of his child only if he complied with a state procedure by which men, but not women, could legitimate their children. Parham, 441 U.S. at 348-49, 355. 
the right to veto an adoption unless they had abandoned the child or been held unfit, but the unmarried father was given no right to block the adoption that would terminate his relation with the child. ${ }^{132}$ In both cases the fathers had acknowledged, lived with, and supported the children through their early years. The Court divided five to four in each case. ${ }^{133}$ The father in Parham was not allowed to sue for his child's death, whereas the father in Caban was allowed to block the adoption of his children. In Lehr a father who had not developed a relationship with his two-year-old child was denied the opportunity to protest the adoption by the mother and her new husband. The Court, dividing six to three, concluded that this distinction between the rights of unwed mothers and fathers was constitutional. The dissenters protested that the father's due process rights had been violated because state law had denied him the opportunity for review of his interest in his relationship with the child. ${ }^{134}$

In all three cases, the Justices approving the state policies based their decisions on the ground that the laws accurately reflected biologi-

132 Caban, 441 U.S. at 385-87.

133 In both cases Chief Justice Burger and Justices Stewart, Rehnquist, and Stevens voted to uphold the sex discriminatory state policy, and Justices White, Brennan, Marshall, and Blackmum supported the father's claim. Justice Powell provided the swing vote, writing the opinion of the Court in Caban and concurring separately in Parham.

Justice O'Connor has sometimes evidenced noteworthy sympathy for the interests of unmarried women and their children. In Mills v. Habluetzel, 456 U.S. 91 (1982), the Court unanimously agreed that a one-year statute of limitations for suits to establish paternity unconstitutionally restricted the rights of illegitimate children. Justice Rehnquist's opinion for the Court suggested that a four-year limitation might be permissible. Justice O'Connor concurred separately to make plain her skepticism that a four-year limit could be justified:

[I]f, because of the continuing relationship between the natural father and the mother, the father has provided the child with financial support for several years, the mother understandably would be unlikely or even unwilling to jeopardize her relationship with the child's father by filing a paternity suit in order to protect her child's right to financial support at some indeterminate future date. Alternatively, the child may have lived with the father alone or his relatives for a number of years, a situation that leaves the child obviously unable to sue his father to establish paternity.

Id. at 105-06 (O'Connor, J., concurring) (footnote omitted).

Justice O'Connor also noted that:

[t]he unwillingness of the mother to file a paternity action on behalf of her child, which could stem from her relationship with the natural father or, as the Court points out, from the emotional strain of having an illegitimate child, or even from the desire to avoid community and family disapproval, may continue years after the child is born. The problem may be exacerbated if, as often happens, the mother herself is a minor.

Id. at 105 n.4.

${ }^{134}$ Lehr, 103 S. Ct. at 2997-3001 (White, J., dissenting). 
cal differences between men and women. Several of these Justices concluded that because the laws reflected biological differences they were not subject to intermediate scrutiny. Justice Stewart's plurality opinion in Parham illustrates the approach. ${ }^{135}$ In Justice Stewart's view, because unmarried men and women were not similarly situated in regard to the law's classification, the state needed only meet the rational relation test. ${ }^{138}$ The difference between men and women was that "[u]nlike the mother of an illegitimate child whose identity will rarely be in doubt, the identity of the father will frequently be unknown."137 Justice Stewart expanded on this theme in his dissenting opinion in Caban: "Parental rights do not spring full-blown from the biological connection between parent and child. . . . The mother carries and bears the child, and in this sense her parental relationship is clear. The validity of the father's parental claims must be gauged by other measures." 138 Consequently, the state classification "reflects the physical reality that only the mother carries and gives birth to the child, as well as the undeniable social reality that the unwed mother is always an identifiable parent and the custodian of the child."

In a separate dissent in Caban, Justice Stevens, who is often an articulate supporter of sex equality, ${ }^{140}$ provided the most extensive statement of the biological justification for this sex-based discrimination. Analytically, Justice Stevens's approach is very similar to Stewart's. For Stevens, the existence of biological differences between men and women meant that the government should not have the burden of demonstrating the value and utility of the classification, as it would if intermediate scrutiny were applied. ${ }^{141}$ Stevens expanded upon the uncontestable fact that mothers and fathers have a different relationship to the child during pregnancy and pointed to social science evidence indicating that "a physical and psychological bond immediately develops between the [mother and infant] that is not then present between the

138 Parhain, 441 U.S. at 348-59 (plurality opinion of Stewart, J.).

${ }^{138}$ See id. at 355-56 (stating that men and women are not similarly situated); id. at 357 (stating that state classification meets rational relation test).

${ }_{137}$ Id. at 355. Apparently Justice Stewart thought it was also relevant that the state allowed men but not women to legitimate a child by unilateral action. See id. As Justice White pointed out in his dissent, however, this statutory distinction, which may itself be unconstitutional, can hardly justify a conclusion that men and women are not similarly situated. See id. at $361 \mathrm{n.2}$ (White, J., dissenting).

${ }^{138}$ Caban, 441 U.S. at 397 (Stewart, J., dissenting) (emphasis added).

199 Id. at 399 (emphasis added).

140 See, e.g., Harris v. McRae, 448 U.S. 297 (1980) (Stevens, J., dissenting); Carey v. Population Services International, 431 U.S. 678 (1977) (Stevens, J., concurring in part and concurring in the judgment); Gilbert v. General Electric Co., 429 U.S. 125 (1976) (Stevens, J., dissenting).

${ }^{141}$ Caban, 441 U.S. at 409-10 (Stevens, J., dissenting). 
infant and the father or any other person."142 $\mathrm{He}$ then claimed that:

differences [between the mother and father] continue at birth and immediately thereafter. During that period, the mother and child are together; the mother's identity is known with certainty. The father, on the other hand, may or may not be present; his identity may be unknown to the world and may even be uncertain to the mother. These natural differences between unmarried fathers and mothers make it probable that the mother, and not the father or both parents, will have custody of the newborn infant.

In short, it is virtually inevitable that from conception through infancy the mother will constantly be faced with decisions about how best to care for the child, whereas it is much less certain that the father will be confronted with comparable problems. ${ }^{143}$

To give the father a right to veto the adoption of his child would "remove the mother's freedom of choice in her own and the child's behalf without also relieving her of the unshakable responsibility for the care of the child."144 In contrast to this view of the mother's "unshakable responsibility" for the child, in Lehr Justice Stevens described the father's relation with his child, suggesting that

[t]he significance of the biological connection is that it offers the natural father an opportunity that no other male possesses to develop a relationship with his offspring. If he grasps that opportunity and accepts some measure of responsibility for the child's future, he may enjoy the blessings of the parent-child relationship . ... ${ }^{\mathbf{1 4 5}}$

The assertion of these "natural" differences between men and women is not simply an attempt by the Justices to avoid a higher level of scrutiny of the classification. For example, Justice Powell, who concurred in the result in Parham and thereby provided the decisive vote upholding the state's wrongful death rule, found the differences between a mother and father to be relevant when he applied the higher, intermediate standard to the classification. He concluded that the differential treatment of the father was permissible because "[t]he marginally

142 Caban, 441 U.S. at 405 n.10 (Stevens, J., dissenting). Justice Stevens begins his argument with the recognition that "both parents are equally responsible for the conception of the child out of wedlock." Id. at 404 .

${ }^{143} I d$. at 405-06 (emphasis added) (footnotes omitted).

${ }^{144} I d$. at 408 (emphasis added).

${ }^{245}$ Lehr, 103 S. Ct. at 2993. 
greater burden placed upon fathers is no more severe than is required by the marked difference between proving paternity and proving maternity." ell's intermediate scrutiny because there was less difficulty in proving paternity in the adoption context. ${ }^{\mathbf{1 4 7}}$

The approach to gender discrimination in these cases is a striking illustration of how the Court's equal protection paradigm actually establishes few limitations on the government's ability to establish gender classifications. More importantly, the facts of the cases reveal the inaccuracy of the stereotypes asserted by the various Justices as "biological fact." There was no doubt as to the identity of these fathers. In Caban, the parents lived together for five years, until the youngest child was almost three. When the mother left, with the children, the father continued to visit them for nine months at which time the children left both parents to live with the maternal grandmother in Puerto Rico. The children stayed there for one year and both parents communicated with them by mail. Then the father went to Puerto Rico, where the grandmother "willingly surrendered the children" to him, with the understanding they would be returned in a few days. He took them back to New York with him. The mother sought and obtained a temporary custody order. Both parents, with their new spouses, then filed cross petitions to adopt the children. ${ }^{148}$ During the eight years from the time the parents began living together until the filing of the conflicting adoption claims, with the exception of the nine months when the children lived with their mother and regularly visited their father, nothing in the record indicates that either parent was more responsible for the care, nurture, and support of the children. In Parham all that we know about the father whose child was killed is that he signed the birth certificate, provided support, and visited his child on a regular basis. ${ }^{\mathbf{1 4 9}}$ We know nothing about the mother, except that she and the child were in the same car when they were killed. ${ }^{150}$ In $L e h r$, the parents lived

146 Parham, 441 U.S. at 360 (Powell, J., concurring).

147 Responding to the presumption established by the Georgia state statute that the roles of parents differ, Justice Powell noted, "Maternal and paternal roles are not invariably different in importance. Even if unwed mothers as a class were closer than unwed fathers to their newborn infants, this generalization concerning parent-child relations would become less acceptable as a basis for legislative distinctions as the age of the child increased." Id. at 389. Justice Powell later expanded on the changing nature of the father's relation to the child: "Even if the special difficulties attendant upon locating and identifying unwed fathers at birth would justify a legislative distinction between mothers and fathers of newborns, these difficulties need not persist past infancy." Id. at 392.

148 Caban, 441 U.S. at 382-84.

148 See Parham, 441 U.S. at 349.

150 See id.; see also Hughes v. Parham, 241 Ga. 198, 243 S.E.2d 867 (1978) 
together for two years prior to the child's birth. The father visited the mother and child in the hospital. Upon leaving the hospital with the child, the mother concealed her whereabouts from him. He diligently searched for them and eventually found them with the aid of a private investigator. ${ }^{181}$ Finally, he filed a petition in court to establish paternity of the child, before being advised of the pending adoption proceeding.

One of the core infirmities of sex-based classifications is that they are unjust in relation to individuals who do not fit the stereotypes. ${ }^{162}$ In these cases the stereotype of the absent, unknown, irresponsible father was simply false.

The stereotype of the mother's "unshakable responsibility for the care of the child," facing the "virtually inevitable" need to make decisions for her child, is also sometimes inaccurate. Significant numbers of women place their children for adoption at or prior to birth. ${ }^{163}$ It is not unheard of for a woman, after giving birth, to simply walk away, leaving the baby to the care of others. How then is it "virtually inevitable that . . . the mother will constantly be faced with decisions about how best to care for the child"? ${ }^{154}$ She can, and sometimes does, make only one decision-to leave.

Justice Stevens in Caban attempts to answer the claim that the sex-based presumption of the New York adoption law is unjust as applied to the individual father who had assumed responsibility for his children.

If we assume, as we surely must, that characteristics possessed by all members of one class and by no members of the other class justify some disparate treatment of mothers and fathers of children born out of wedlock, the mere fact that the statute draws a "gender-based distinction," . . . should not, in my opinion, give rise to any presumption that the impartiality principle embodied in the Equal Protection Clause has been violated. Indeed, if we make the further undisputed assumption that the discrimination is justified in those cases in which the rule has its most frequent application-cases involving newborn infants and very young chil-

(Georgia Supreme Court opinion below).

Parham was not litigated as a test case. No amicus briefs were filed by either children's rights or women's rights organizations. 441 U.S. at 348 . By contrast, the father's claim in Caban was supported by the AGLU, Community Action for Legal Services, and the Legal Aid Society as amicus. 441 U.S. at 381.

181 Lehr, 103 S. Ct. at 2997.

162 See also Frontiero v. Richardson, 411 U.S. 677 (1973).

183 See, e.g., Caban, 441 U.S. at 404 n.7.

164 Id. at 406 (emphasis added). 
dren in the custody of their natural mothers-we should presume that the law is entirely valid and require the challenger to demonstrate that its unjust applications are sufficiently numerous and serious to render it invalid. ${ }^{155}$

It is quite unclear what is meant by "characteristics possessed by all members of one class." Certainly it is not universally true that women assume responsibility for the care of infants at birth and men do not. Justice Steven's suggestion that sex-based discrimination is justifiable when it reflects prevailing social patterns is familiar. The Court has long held that "the rules of civil society must be adopted to the general constitution of things, and cannot be based upon exceptional cases." 158 That language is from Mr. Justice Bradley's classic defense of the natural subordination of women in Bradwell v. Illinois. ${ }^{\mathbf{1 5 z}}$

${ }^{155}$ Id. at 409-10 (emphasis added) (footnote omitted).

158 Bradwell v. Illinois, 83 U.S. (16 Wall.) 130, 141-42 (Bradley, J., concurring).

187 Id. The Parham majority, in addition to relying on the biological difference between "proving paternity and proving maternity," upheld the Georgia law denying unmarried fathers the right to sue for the wrongful death of their child as one discriminatory part of a larger discriminatory whole. Georgia law provided a process by which unmarried fathers, but not unmarried mothers, could legitimate their children. This larger discriminatory whole justified the particular discriminatory part. 441 U.S. at 354-56.

The Court does not always get trapped in this circle, in which one discriminatory policy justifies another. For example, in Orr v. Orr, 440 U.S. 268 (1979), the state attempted to defend its rule providing alimony only to women, arguing that the provision of alimony was a form of compensation for the married woman whose property became her husband's at common law. In striking down the statute as violative of the equal protection clause of the fourteenth amendment, the Court said,

This argument, that the "support obligation was imposed by the common law to compensate the wife for the discrimination she suffered at the hands of the common law," . . . reveals its own weakness. At most it establishes that the alimony statutes were part and parcel of a larger statutory scheme which invidiously discriminated against women, removing them from the world of work and property and "compensating" them by making their designated place "secure." This would be reason to invalidate the entire discriminatory scheme-not a reason to uphold its separate invidious parts.

440 U.S. at 279 n.9.

In Parham it seems that the Court adopted the circular logic because of a lack of clear focus on the myth and reality of sex-based biological difference.

Apart from classifications touching upon biological difference, the other area in which the Court has allowed a larger sex discriminatory whole to justify a particular sex discriminatory part is in classifications affecting military service. See Rostker v. Goldberg, 453 U.S. 57 (1981); Califano v. Webster, 430 U.S. 313 (1977); Califano v. Goldfarb, 430 U.S. 198 (1977); Schlesinger v. Ballard, 419 U.S. 498 (1975).

In the military cases the Court has relied upon the fact that women are excluded from most combat positions to justify allowing them more time to prove their worth for promotion (Schlesinger) and to justify the exclusion of women from draft registration (Rostker). The Court has not been presented with a case challenging the exclusion from combat. See Goodman, Women, War and Equality: An Examination of Sex Discrimi- 
Although sex-based classifications are unjust in relation to individuals, like the fathers in Caban and Parham or the woman in Bradwell who do not fit the stereotypes imposed on them, the primary constitutional infirmity in such classifications is not that they are inaccurate, but rather that they are self-fulfilling. The stereotype of women accepting the "unshakable responsibility for the care of the child" is overwhelmingly accurate. ${ }^{158}$ Most women do take responsibility for

nation in the Military, 5 WOMEN's RTS. L. REP. 243 (1979) (discussing the overbreadth of the combat exclusion and the damage it does to women in the military); see also Williams, supra note 199.

158 For example, although Aid to Families with Dependent Ghildren (AFDG) is available to any needy parent or other single caretaker of a minor child, over $98 \%$ of the families receiving AFDC are headed by women. The percentage of AFDC families consisting of a man and children has remained relatively constant over recent years, ranging from a low of $1.2 \%$ in 1973 to a high of $1.6 \%$ in 1977. See BUREAU OF THE Gensus, U.S. Dep't of Commerce, Statistical Abstract of the U.S. 1979, at 357.

For another example, a 1981 report by the U.S. Civil Rights Commission found that "a substantial number of women, especially minority women, are prevented from taking paid work because of unavailable or inadequate child care." U.S. CoMM'N ON Givil Rights, Ghild Care and Equal Opportunity for Women 9 (1981). Approximately one of every five unemployed women is unable to work because she cannot make satisfactory child care arrangements. U.S. CoNG. BUDGeT OFfice, GHILdREN AND PReschool: Options fOR FeDeral SupPoRT 47 (1978). A recent analysis of national survey data shows that $23 \%$ of single and married working mothers find that breakdowns in child care arrangements cause them to be late for or absent from work. Almost no fathers reported such problems. OFFICE OF THE AsSISTANT SECRETARY FOR Policy, Evaluation, and Research, Dep'T of Labor, Work and Family Life: First Reports on WORK-Family INTERFERENCE and WORKERS' Formal ChILD Care Arrangements from the 1977 Quality of Employment SuRvey, 1978, table.

Women do most of the work of homemaking and child care even when two parents are in the home. One study shows that, on the average, the hours women devote to such work varies from 28 hours per week for women with no children who are employed at full time wage labor to 84 hours a weeks for women with seven or more children who are not also doing wage work. Men spend an average of 10.5 hours a week on housework and childcare, and there is little variation in male contribution when the woman is employed outside the home. Walker and Gauger, The Dollar Value of Household Work, NYS SchOOL OF HuMAN EcOLOGY, INFORMATION BULL. 60 (1973); see also A. OAKLEY, The Sociology of Housework (1974).

When married couples separate, the woman takes custody of the children about $90 \%$ of the time, most often by mutual agreement of the parties. M. WHEELER, DIvided Children: A Legal Guide for Divorcing Parents 40 (1980). When it is contested, men succeed in obtaining custody in more than half the cases. Pollikoff, Gender and Child-Custody Determinations: Exploding the Myths, in Familes, Pourtics, and Public Policy: A Feminist Dialogue on Women and the State, 183, 184 (I. Diamond ed. 1983) Klaff, The Tender Years Doctrine: A Defense, 70 CalIF. L. REv. 335, 335 n.3 (1982); Orthner and Lewis, Evidence of Single-Father Competence in Childrearing, 13 FAM. L. Q. 27 (1979); Weitzman and Dixon, Child Custody Awards: Legal Standards and Empirical Patterns for Child Custody, Support, and Visitation After Divorce, 12 U.C.D. L. REv. 473 (1979).

Despite profound changes in the status of women in the past 15 years, women still do most of the work in the home. Blumstein and Schwartz, AMERICAN Couples 144- 
their children, often against terrible obstacles, sacrificing their own interests to their children's needs every day, in large matters and small. And it is a very good thing for children that they do. John MacMurray observes,

The baby must be fitted by nature at birth to the conditions into which he [sic] is born; for otherwise he could not survive. $\mathrm{He}$ is, in fact, "adapted" to a complete dependence upon an adult human being. He is made to be cared for . . . not merely his personal development, but his very survival depends upon the maintaining of this relation .... He cannot live at all by any initiative, whether personal or organic, of his own. He can live only through other people and in dynamic relation with them. ${ }^{159}$

Although it is critical for children that someone assume responsibility for them, that response is not determined by biology. The Court asserts that, for men, parenthood is an "opportunity" for nurturing. ${ }^{160}$ So too for women. But caring for the children that we parent, and for the ones that we don't, is more than an opportunity, it is also a responsibility. Biology does not determine who cares for a child after birth. When the Supreme Court assumes it does, the Court confuses biology with social patterns and sex-based stereotypes.

In taking responsibility for children women act as independent moral agents. When the Supreme Court assumes that "biology" dictates that women care for infants, it is impossible to attach moral value to the woman's actions or to acknowledge the human and social worth of the nurturing that women do. When the Court allows sex-based classifications to be justified by the presumption that fathers are unidentified, absent, and irresponsible, it is more likely that these generalizations will continue to be true. Assertions that it is "virtually inevitable" that the mother will care for the child, assumptions of her "unshakable responsibility" and the "undeniable social reality that . . . the mother is always . . . the custodian of the child," are no different from the "old notion" that motherhood is "the nobel and benign mission" of women. ${ }^{161}$ The assumption reinforces stereotypes and degrades women.

The stereotype of male irresponsibility in relation to the children

46 (1983).

169 J. MacMurry, Persons in Relation 48-51 (1961).

160 Del Costello v. International Bhd. of Teamsters, 103 S. Ct. 2281, 2293 (1983).

101 Bradwell v. Illinois, 83 U.S. 130, 141 (1872). 
they father is also distressingly accurate. ${ }^{162}$ It is a core social problem of our time. ${ }^{163}$ The problems created by men who fail to provide their children financial support are widely recognized, ${ }^{164}$ as are the problems facing women who cannot achieve equality in wage work or public life while doing the work essential to meet the needs of children. ${ }^{165}$ When the Gourt upholds a statutory scheme because it considers fatherhood solely in terms of "opportunity," and motherhood in terms of "unshakable responsibility," it reinforces stereotypes and perpetuates male irresponsibility.

In addition to reinforcing stereotypes, legal cognizance of these gender "differences" has an impact on child custody litigation:

Gase analysis reveals a tendency to overrate small paternal contributions to parenting because they are still so noticeable, and to concomitantly over-emphasize lack of total maternal parenting. In other words, the emphasis in evaluating mothers is on what they do not do, because they are expected to do everything. By this standard, men will always look good for doing more than nothing and women will always look bad for doing less than everything. ${ }^{166}$

But men's lack of concrete connection with the young raises other, even more serious, problems. Nurturing children-helping the next generation to stand on our shoulders-is one of the most noble tasks of any civilization. Yet few men ever have substantial day-to-day experience with young children. It seems plausible that intense relationships with young children encourage reverence for the future of the species and the planet. It is deeply disturbing that so few men experience such

162 A majority of fathers of all income levels substantially fail to comply with orders requiring that they support their children. See J. GasseTTY, GHILd SUPPORT and Public Policy (1978); D. Chambers, Making Fathers Pay (1979); Chambers, The Coming Curtailment of Compulsory Child Support, 80 Mrch. L. REv. 1614 (1982).

For an excellent analysis of the reasons underlying the failure to enforce child support, see Hunter, Child Support Law and Policy: The Systematic Imposition of Costs on Women, 6 HaRv. WOMEN's L.J. 1 (1983).

16s D. Dinnerstein, supra note 33; N. Chodorow, supra note 33.

164 See supra note 162; see also Locker, Enforcement of Child Support Obligations of Absent Parents-Social Services Amendments of 1974, 30 Sw. L.J. 625 (1976); Mnookin, Review: Using Jail for Child Support Enforcement, 48 U. CHI. L. REv. 338 (1981).

185 See supra note 158.

${ }_{168}$ Polikoff, Gender and Child-Custody Determinations: Exploding the Myths, in Families, Politics, and Public Policy: a Feminist Dialogue on Women and The State, 183, 191 (I. Diamond ed. 1983). See also Polikoff, Why Are Mothers Losing: A Brief Analysis of Criteria Used in Child Custody Determinations, 7 WOMEN's RTS. L. REP. 235, 240-41 (1983). 
relationships, particularly those men who exercise the greatest power in government, business, and education.

Another problem is the effect of absent fathers on children. A broad spectrum of people-feminists, the Catholic Church, Freudians-believes that the early years of a child's life are critical in determining human potential. Adults today were almost all nurtured solely by women, particularly when they were very young. The love and hate we feel for the person who cared for us when we were totally vulnerable and dependent is directed exclusively at women. The phenomenon of exclusive female nurturing of the young has a profound influence on the people that we are, and will be. Children would grow to be different, perhaps stronger, adults if men were involved in their early nurturing. ${ }^{107}$

\section{B, Statutory Rape: Michael M.}

The fourth Supreme Court case involving a sex-based classification justified in relation to biological difference was Michael M. v. Superior Court, ${ }^{\mathbf{1 6 8}}$ which upheld a California statutory rape law making it a crime for a man to have sex with a woman under the age of eighteen. Justice Rehnquist's plurality opinion reflects a belief that women and men are different in ways that are relevant to the state's classification:

Only women may become pregnant, and they suffer disproportionately the profound physical, emotional, and psychological consequences of sexual activity. . . .

Because virtually all of the significant harmful and inescapably identifiable consequences of teenage pregnancy fall on the young female, a legislature acts well within its authority when it elects to punish only the participant who, by nature, suffers few of the consequences of his conduct. ${ }^{168}$

187 "[E]xclusive single parenting is bad for mother and child alike. . . . [M]others in such a setting are liable to overinvest in and overwhelm the relationship. Similarly, I think, children are better off in situations where love and relationship are not a scarce resource controlled and manipulated by one person only." N. CHODOROw, supra note 33 at _. See also supra note 33. For a similar analysis of the effects of exclusively female mothering, see D. DinNERsteIN, supra note 33, at 33-34, 41-82, especially 7172.

In suggesting a need for greater male involvement in the nurture of children, I do not mean to deny the legitimacy of mother-child families. Most children today are nurtured by women, including children in conventional heterosexual two-parent homes.

${ }_{188} 450$ U.S. 464 (1981).

${ }^{169}$ Id. at $471-73$ (plurality opinion of Rehnquist, J.). 
Rehnquist's opinion never actually stated, however, whether these differences mean that this is not an appropriate case in which to apply the Craig standard. Based on the assumption that prevention of teenage pregnancy was the purpose of the sex-based classification, ${ }^{\mathbf{1 7 0}}$ Rehnquist concluded only that the law was "sufficiently related to the State's objectives to pass constitutional muster." ${ }^{\prime 71}$ In any event, the perceived differences between men and women were crucial to the opinion. ${ }^{172}$

The precise contours of the analysis in Justice Blackmun's concurring opinion are even more obscure. His assessment of the presence and impact of gender differences is simply not included in the opinion. ${ }^{173}$

As in the three cases discussed earlier, the Michael $M$. plurality does not evaluate with care the gender differences upon which it relies in upholding the state law. This failure of analysis means that the plurality also mistakes stereotype for biology. In fact, it is not entirely nature that imposes upon women the devastating burdens of teenage preg-

170 See id. at 470 .

171 Id. at 473.

172 Justice Stewart, concurring, also relied upon biological difference to justify the sex-based classification. "The risk of pregnancy is a significant deterrent for unwed young females that is not shared by unmarried males, regardless of their age. Experienced observation confirms the commonsense notion that adolescent males disregard the possibility of pregnancy far more than do adolescent females." Id. at 480.

${ }^{173}$ Justice Blackmun's assessment of the conduct at issue in Michael $M$. is included, however, and that assessment is disturbing. Justice Blackmun provides extensive quotes from Sharon's testimony at the preliminary hearing. See id. at 483-88 n.*. Sharon and Michael met at a bus stop the night the intercourse took place. Sharon and an older sister were slightly drunk, waiting for a bus about midnight. Michael and two other boys picked them up, and the five drank some more. Sharon and Michael began kissing and separated from the others. Sharon asked Michael to slow down, told him she did not want to have intercourse, and "let him do what he wanted" only after he hit her several times, causing bruises to her face. Id. at 483-85 n.*. Justice Blackmun characterized the facts, by saying,

that Michael and Sharon's nonacquaintance with each other before the incident; their drinking; their withdrawal from the others of the group; their foreplay, in which she willingly participated and seems to have encouraged; and the closeness of their ages (a difference of only one year and 18 days) are factors that should make this case an unattractive one to prosecute at all, and especially to prosecute as a felony .... But . . . the facts, I reluctantly conclude, may fit the crime.

Id. at 483-87.

Frances Olsen observes that "Blackmun's reaction would seem to be that Sharon did not fit the 'chaste and naive' image. ... [He] endorses the double standard of sexual morality, in which men may aggress sexually against one class of females but must leave the higher class chaste. Since Michael did not transgress this rule, it is not fair to him to bring a felony prosecution." Olsen, Towards a New Feminist Jurisprudence: The Case of Statutory Rape, TEx. L. REv. text at note 118 (1984). She characterizes the transcript as "an indictment of the warped human relations that take place in a gender-stratified society. . . . The testimony captures the confused yearnings for closeness and the frustrated anger that can make adolesence so painful a time-for both females and males-in our society." Id. at n.212. 
nancy; the social and legal ethos that makes women solely responsible for nurturing the children they bear also plays a part. Justice Rehnquist asserts that "the risk of pregnancy itself constitutes a substantial deterrence to young females. No similar natural sanctions deter males."174 Of course, men are not deterred because fatherhood is now only an "opportunity" not a responsibility; men are not morally accountable to their children. That is simply "nature," the way things are, and the state is free to recognize this biological "reality." The presumptions underlying Justice Rehnquist's assertions are appalling. They inescapably reinforce the legitimacy of male irresponsibility in relation to their children. They also prevent us from seeing that women are people who make moral choices and from valuing the nurturing choices women make.

Michael $M$. also accepts and reinforces the sex-based stereotypes that men are naturally, biologically aggressive in relation to sex, while women are sexually passive, and that young women need the law's protection from their own weakness. ${ }^{175}$ In sex, the man is the offender and the woman the victim. ${ }^{\mathbf{1 7 6}}$ The social problem of male aggression, both generally ${ }^{177}$ and in relation to sex, ${ }^{178}$ cannot be understated. The social problem of female passivity is more subtle but nonetheless real. When the Court acts on the assumption that these stereotypes are natural, biological, and inalterable, it reinforces and perpetuates the stereotypes.

174 Michael M., 450 U.S. at 473.

178 The protection of the chastity of young girls was seen as the purpose of the statutory rape law until the Michael M. litigation. See id. at 495-96 n.10 (Brennan, J., dissenting).

178 Justice Rehnquist uses the terms "offender" and "victim" when describing how the California Supreme Court had justified the statutory rape law. See id. at 467 (plurality opinion of Rehnquist, J.).

177 FBI statistics show that males are much more likely to be arrested for violent crimes than are females. For murder and non-negligent manslaughter, $87.3 \%$ of the arrests were males; for aggravated assault, $87.4 \%$ were males; and for robbery, $92.8 \%$ were males. Federal Bureau of Investigation, U.S. Dep't of Justice, 1981 UNIFORM CRIME REPORTS 178 (1982).

${ }_{178}$ Forcible rape accounts for $6 \%$ of reported violent crimes against people in the United States. National statistics show that in 1980 reported forcible rape offenses were up $8 \%$ over 1979 figures and up 45\% over 1976 figures. "Even with the advent of rape crisis centers and an improved awareness by police dealing with rape victims, forcible rape, a violent crime against the person, is still recognized as one of the most underreported of all Index crimes." Federal BuReau of Investigation, U.S. Dep'T OF JUSTICE, 1980 UNIFORM CRIME REPORTS 15 (1981).

A random study of 4,000 American women in the early 1950 's revealed that $24 \%$ had experienced a sexual encounter with an adult prior to age 13. A. KINSEY, W. Pomeroy, C. Martin \& P. Gebhard, Sexual Behavior in the Human Female 117 (1953). This and a variety of other studies suggest that in 80 to $90 \%$ of cases a man is the offender. F. Rush, The Best KePt Secret: Sexual Abuse of Children 2-4 (1980). Another investigator finds that $97 \%$ of incest offenders are male. See L. Schirhart, The Silent Children 195 (1980). 
Michael $M$. also accepts and reinforces the sex-based stereotype that young men may legitimately engage in sexual activity and young women may not. As Professor Frances Olsen has observed, under the California law a young man is free to be sexual as long as he chooses a partner who is older than eighteen, while a young woman may not legally have sex with anyone, except her husband if she is married. ${ }^{178}$ These sex-differentiated assumptions about the legitimacy of sexual expression are so ingrained that the plurality, concurring, and dissenting opinions ignored them.

A statutory rape law may well be a reasonable device for protecting relatively powerless people from coercion exerted by those who are relatively more powerful, and age might reasonably serve as a proxy for power. But the California law "protects" young women from heterosexual intercourse with men of any age, while not offering similar protection to young men. By penalizing men, but not women, who have sex with young people, it denies the possibility of female sexuality. Again, none of the Court's opinions discussed this sex-based differentiation.

These cases illustrate more than the Court's consistent confusion of biology with the social consequences of biology. They also demonstrate the breakdown in current sex equality doctrine that occurs when the Court reviews a classification that, in its view, is based upon biological differences. In such cases it is likely that the Court will either (1) defer to the governmental body that adopted the rule, requiring only that a rational relation test be met, or (2) apply the Craig test in form only, in either case, adjusting its review to account for what it understands to be the real difference between the sexes. ${ }^{180}$

179 See Olsen, supra note 173; supra text accompanying notes 108-09.

180 The failure of the Court to subject biological classifications to careful scrutiny by considering whether sex-neutral statutes would achieve the state's purpose can be seen in the application of the test in the cases just discussed. In the three cases that considered the rights of unwed fathers, the state could have provided that any parent who abandoned a child without justification or excuse would have no right to object to the adoption. For example, Justice Powell found in Caban that

where the father never has come forward to participate in the rearing of the child, nothing in the Equal Protection Clause precludes the State from withholding from him the privilege of vetoing the adoption of the child. Indeed, under the statute as it now stands the surrogate may proceed in the absence of consent when the parent whose consent otherwise would be required never has come forward or has abandoned the child.

441 U.S. at 392 (footnote omitted).

The standard the Court articulates in Lehr is consistent with this approach: "If one parent has an established custodial relationship with the child and the other parent has either abandoned or never established a relationship, the Equal Protection Clause does not prevent a state from according the two parents different legal rights." $103 \mathrm{~S}$. Ct. at 2996-97 (footnotes omitted). Establishing a gender-neutral rule would still allow 
The results in Parham and Michael M., as well as the analysis in all four cases, might have been different had the Court perceived the distinction between laws based on sex and laws based on sex-specific biology and had it recognized that laws governing reproductive biology also implicate equality concerns and demand careful scrutiny. The next section will attempt to identify a new test for classifications based on biological differences.

\section{A Proposed Approach to Sex-Based Equality and Biological Difference}

Before proposing a new approach to classifications based on biological differences, it is useful to identify initially how such classifications would be evaluated under several alternative approaches to sex equality. Once the advantages and limitations of these approaches are outlined, a more coherent approach will be charted.

for prompt settlement of adoption proceedings by avoiding hard questions of proof. Unless the father is on the scene and provides material support or communicates a good excuse for his absence at the time of birth, he can sensibly be held to have abandoned his child. We would not hesitate to apply exactly the same rule to the mother who left the hospital without her infant and stayed away for more than a very brief period. The needs of infants are such that anything less than constant attention quickly becomes abandonment. The man who seeks the company of an infant, provides the intensive support, care, and nurturance that infants demand and then claims, without reasonable basis, that he is the father would be very rare.

If we assume that the purpose of the statute in Michael $M$. was to prevent teenage sex and pregnancies, a sex-neutral statute again would have allowed the state to meet its interest equally effectively. Many states have adopted neutral statutes prohibiting sex with minors. The sex-based statute of Michael $M$., far from serving important state interests, was probably a less effective deterrent to teenage sex than the neutral alternatives. See Michael M., 450 U.S. at 493-94 and nn.7-8 (Brennan, J., dissenting); id. at 498-500 (Stevens, J., dissenting).

If, on the other hand, California had been seeking to protect young and relatively powerless people from sexual relationships with older and relatively more powerful people, it could have made it a crime for any adult to have sex with a child under a fixed age or with a child who is more than a fixed number of years younger than the adult. Or, if the legislature also wanted to prohibit sexual relationships among teenagers, it could have penalized all teenagers who engaged in sexual activities.

There is certainly a distinction between a desire to protect vulnerable teenagers from coercive sexual relations with older people and a desire to prohibit all sexual activity by teenagers. If we want to protect vulnerable young people, we should not subject them to prosecution. Justices Stevens and Brennan, dissenting in Michael M., suggested approval of a sex neutral law under which both parties would be subject to prosecution. Stevens refers to the California statute as "exempt[ing] 50\% of the potential violators," id. at 499 (Stevens, J., dissenting), and Brennan argues that under a "gender-neutral law" twice as many persons would be "subject to arrest," id. at 494 (Brennan, J., dissenting). The dissenters' version of sex-neutrality demands that vulnerable teenagers incriminate themselves in order to claim the law's protection against coerced sex. 


\section{A. Understanding Biological Differences According to Current Notions of Sex-Based Equality}

It is possible to construct a constitutional sex equality concept in which laws governing sex-specific physical characteristics will have one of the following three implications: (1) the laws raise no concerns about sex equality; (2) the laws are considered in the same way as laws that classify explicitly on the basis of sex; and (3) the laws are considered under a reconceptualized idea of equality that applies a new, integrated test to any sex-related classification.

The first approach is essentially the Supreme Court's notion of sex equality-one in which laws governing reproductive biology raise no sex equality concerns. ${ }^{181}$ As the Court stated in Geduldig v. Aiello, ${ }^{182}$ for example, "[W]hile it is true that only women can become pregnant it does not follow that every legislative classification concerning pregnancy is a sex-based classification."183 This approach clearly denies the core reality that sex-based biological differences are related to sex. It is not easy to reconcile the ideal of sex-based equality with the reality of categorical biological difference, but the difficulty is not overcome by denying that laws governing reproductive biology are sex based. Further, because, as we have seen, it is easy for the Court to confuse real categorical biological differences with sex-based differences that are culturally imposed, an equality doctrine that exempts laws based on real physical differences from its concern is likely to be a weak one. Finally, and most importantly, in a society constitutionally committed to equality, the reality of biological difference in relation to reproduction should not be permitted to justify state action exaggerating the consequences of those differences. This is what happens when those actions escape scrutiny by courts.

The second approach to reconciling the ideal of equality with the reality of biological difference scrutinizes laws regulating reproductive differences in the same manner as laws that include explicit sex-based classifications using the Court's current gender-discrimination standard. ${ }^{184}$ This approach has the virtue of simplicity. It recognizes that

181 See, e.g., supra notes 106-15 and accompanying text.

182417 U.S. 484 (1974).

183 Id. at 496 n.20.

184 For example, Justice Brennan has argued that "dissimilar treatment of men and women, on the basis of physical characteristics inextricably linked to one sex, inevitably constitutes sex discrimination." Geduldig, 417 U.S. at 501 (Brennan, J., dissenting). He criticized the Geciuldig majority for failing to explain "what differentiates the gender-based classification employed in this case from those found unconstitutional in Reed and Frontiero." Id. at 503. 
laws based on sex-specific physical characteristics are related to sex and avoids the need to distinguish between these two types of sex-based laws.

The difficulty with this approach is that a central justification for limiting the use of explicit sex-based classifications is that they are not related to real differences between men and women. By contrast, laws governing reproductive characteristics, such as those prohibiting abortion or providing nutritional supplements for pregnant women, ${ }^{\mathbf{1 8 5}}$ may be precisely related to the individual characteristics of the people they identify. The prevailing sex equality standard determines whether the sex-based classification at issue actually is responsive to real differences between men and women and rejects classifications when there are no such differences. This standard usually works in relation to explicit sex-based classifications because individual men and women escape stereotypical sex roles. ${ }^{188}$ The escapees disprove the judgment about men and women that motivated the explicit sex-based classification. However, because there are no escapees from biology, no pregnant men, or women sperm donors, a standard focusing solely on comparative equality does not provide a helpful tool for evaluating laws governing ways in which men and women categorically, biologically differ.

This second approach is also troubling because of a related concern. As a practical matter, it is difficult to maintain an appropriately rigorous standard for evaluating the cultural restraints of explicit sexbased classifications if the same standard is also used to judge laws

${ }^{185}$ The Maternal and Child Health Services Block Grant Program under Title V of the Social Security Act, 42 U.S.C. $\$ \S 701-709$ (Supp. V 1981), provides grants and aid to state health departments for certain health services. The program has two components: (1) health services for maternity, delivery and preventive infant health care; and (2) crippled children's services. States have used some of the funds for pre-natal and well-baby clinics.

The Special Supplemental Food Program for Women, Infants, and Children (WIC), see 42 U.S.C. $\S 1786$ (Supp. V. 1981), is a food supplement program that is targeted to pregnant and lactating women, infants, and young children. To qualify, the family must have an inadequate income and the individual must be a nutritional risk. Income eligibility guidelines are set by the Secretary of Agriculture and the nutritional risk category must be certified by a competent professional authority. The program provides nutritional supplements through vouchers or food packages as well as some preventive health care, educational programs, and referrals.

${ }_{180}$ Under Title VII, the Court has held that explicit sex-based classifications cannot be used, even where they describe statistically accurate differences between men and women because Title VII's "focus on the individual is unambiguous." City of Los Angeles Dep't of Water \& Power v. Manhart, 435 U.S. 702, 708 (1978), reaffirmed in Arizona Governing Comm. for Tax Deferred Annuity \& Deferred Compensation Plans v. Norris, 103 S. Ct. 3492 (1983).

Under the fourteenth amendment the Court has invalidated sex-based classifications, even where they rest on "predictive empirical relationships" that are more or less accurate in the aggregate. See Craig v. Boren, 429 U.S. 190, 202 (1976). 
governing sex-specific physical characteristics. Similarly, we have already seen how the Supreme Court's current intermediate scrutiny may become much more deferential when the Court perceives that a rule is based on "real" differences between the sexes. ${ }^{187}$ A better approach would consider laws based on biological differences independently of laws employing categorical sex-based classifications, thereby reducing the Court's ability to distort its intermediate scrutiny in this way.

The final approach, as advocated by Professor Catherine MacKinnon, attempts to grapple with the pervasive totality of sex-based oppression. She describes sex discrimination as a systematic construct that defines women as inferior to men and "that cumulatively disadvantages women for their differences from men, as well as ignores their similarities."188 She urges a constitutional equality standard that would ask simply "whether the policy or practice in question integrally contributes to the maintenance of an underclass or a deprived position because of gender status."189

Professor MacKinnon's approach is ambitious, but it adds unnecessary complexity to the application of sex equality doctrine in a large number of cases. The determination of what reinforces or undermines a sex-based underclass is exceedingly difficult. Professor MacKinnon may overestimate judges' capacities to identify and avoid socially imposed constraints on equality. ${ }^{190}$ She disregards our history in which laws justified as protecting women have been a central means of oppressing them. ${ }^{191}$ Most fundamentally, her proposed standard may incorporate and perpetuate a false belief that a judicially enforced constitutional standard can, by itself, dismantle the deep structures that "integrally contribute" to sex-based deprivation. ${ }^{\mathbf{1 9 2}}$

MacKinnon discusses how sex equality doctrine can focus on an analysis of either "differences" between sexes (current doctrine) $)^{193}$ or "inequality" (her proposed doctrine). ${ }^{104}$ MacKinnon correctly contends that under current gender doctrine, "[i]f the sexes can be considered relevantly the same, 'similarly situated,' or comparable on the dimension in question, differential treatment may be discriminatory; if not, differential treatment merely treats differences differently and is not.

${ }^{187}$ See, e.g., supra notes $146-47 \& 181$ and accompanying text.

188 See C. MacKinnon, supra note 41, at 116.

189 Id. at 117.

${ }^{100}$ See generally Taub \& Schneider, Perspectives on Women's Subordination and the Role of Law, in THE Politics of LAw (D. Kairys ed. 1982).

191 See supra notes 11-14 and accompanying text.

192 See supra note 8 and accompanying text.

193 See C. MacKinnon, supra note 41, at 101-02.

194 See id. at 102-03. 
discriminatory."195 We have seen, and MacKinnon herself argues, that this comparative analysis leads to the conclusion that there is no sex discrimination when a law is based on real biological differences between men and women. ${ }^{198}$ Notwithstanding this important limitation of current equality doctrine, broad use of

an inequality approach poses tremendous risks. The very invisibility of discrimination against women makes it unlikely that the inequality approach can in fact be utilized successfully by litigators before the present judiciary. When, as in Califano v. Goldfarb, . . . a majority of the Court cannot agree that women are discriminated against by a system of social security benefits that provides greater coverage for the dependents of male workers than it does for the dependents of female workers, there are great dangers in pressing a view that subjects discrimination against women to more exacting scrutiny than it does discrimination against men. It is all too likely that the courts will simply uphold the discrimination because they fail to see that women have been disadvantaged. Moreover, as MacKinnon herself acknowledges, "woman's 'specialness' (is) the cornerstone of that separate-but-equal logic of complementarity that has assigned her those pursuits and those qualities that are glorified as female but denigrated as human. . . ${ }^{107}$

MacKinnon's proposal is mistaken, therefore, because it would require a search for hierarchy when only a search for difference may be necessary. Her approach is helpful, however, because it provides a framework for determining when a rule classifying on the basis of biological differences is actually discriminating on the basis of sex. Such a rule is discriminatory when it "integrally contributes to the maintenance of an underclass or a deprived position because of gender status." 188

The three approaches discussed above unsuccessfully confront the unique problem of evaluating laws based on biological differences. In articulating a new standard for evaluating such laws, I hope to incorporate the strengths while avoiding the weaknesses of these approaches.

198 Id. at 110 . See also id. at 102 ("The gender difference is lined up against the sex difference in practice, and women are compared with men, to see if the correspondences warrant the application.").

198 See id. at 104-05.

187 Taub, Book Review: Sexual Harrassment of Working Women: A Case of Sex Discrimination, 80 Colum. L. REv. 1686, 1691 (1980) (citation omitted).

198 C. MacKinnon, supra note 41, at 117. 


\section{B. A New Approach to Laws Based on Biological Differences}

Professor Wendy Williams observes, "The instinct to treat pregnancy as a special case is deeply imbedded in our culture, indeed in every culture. It seems natural, and right, to treat it that way."199 Yet, this wise feminist and constitutional scholar urges that we resist the temptation to see pregnancy as unique. She argues that

[c]onceptualizing pregnancy as a special case permits unfavorable as well as favorable treatment of pregnancy. . . . [T] he same doctrinal approach that permits pregnancy to be treated worse than other disabilities is the same one that will allow the state constitutional freedom to create special benefits for pregnant women. . . . If we can't have it both ways, we need to think carefully about which way we want to have it. $^{200}$

But pregnancy, abortion, reproduction, and creation of another human being are special-very special. Women have these experiences. Men do not. An equality doctrine that ignores the unique quality of these experiences implicitly says that women can claim equality only insofar as they are like men. Such a doctrine demands that women deny an important aspect of who they are. Such a doctrine is, to say the least, reified. ${ }^{201}$ Further, deny as we might, the reality remains that only women experience pregnancy. If women are to achieve fully equal status in American society, including a sharing of power traditionally held by men, and retain control of their bodies, our understanding of sex equality must encompass a strong constitutional equality guarantee that requires "radically increasing the options available to each individual, and more importantly, allowing the human personality to break out of the present dichotomized system."202

Because of the unique equality concerns raised by biological differences, sex equality doctrine must distinguish between laws drawing explicit sex-based lines and laws governing reproductive biology. Although both types of laws raise sex equality issues, the grounds for concern are different. The problem posed by laws that classify explicitly on the basis of sex is that sex, as a proxy for some functional characteristic, is often inaccurate in relation to particular individuals. More

109 Williams, The Equality Crisis: Some Reflections on Culture, Courts, and Feminism, 7 WOMEN's RTS. L. REP. 175, 195 (1982).

${ }^{200} \mathrm{Id}$.

${ }^{201}$ Gabel, Reification in Legal Reasoning, in 3 RESEARCH IN LAW AND SociolOGY (S. Spitzer ed. 1980).

${ }^{202}$ Olsen, supra note 4, at 1578. 
important, even when the sex generalization is accurate in the aggregate, these generalizations tend to be self-fulfilling and oppressive to the individual who fails to fit the mold. ${ }^{203}$ In using explicit sex classifications the state may perpetuate arbitrary limits on human freedom and equality. Based on these concerns, scrutiny of sex-based classifications is intended to ensure that there are important governmental reasons for treating men and women differently when they are in all relevant respects the same.

Also, the equality issues raised by laws affecting reproductive biology are related, in part, to accuracy, as when the state uses the fact that women may become pregnant to justify barring all women, pregnant or not, from public life and responsible work. In addition, the laws may generate a self-fulfilling expectation, as when the fact that women bear children is used to justify an assumption that women have greater responsibility to nurture them after birth. Because these concerns are raised in a context in which men and women seem to have real differences, the inaccuracy or the stereotype may not be apparent.

Because this context may present differences between the sexes that are relevant to lawmakers, a proper concern for equality requires scrutiny that is directly focused on the impact of the rule rather than its purpose or structure. For example, programs providing material support to pregnant women are not necessarily premised on inaccurate assumptions about their need. Laws restricting or facilitating access to abortion do not inaccurately assume that only women need abortions. Neither type of law crates a culturally imposed constraint on the ability to sustain or to avoid pregnancy. Still, these laws raise equality concerns because state control of a woman's reproductive capacity and exaggeration of the significance of biological difference has historically been central to the oppression of women. When the state bars pregnant women from doing work they are able to do or denies women access to reproductive health services, the state, as well as nature, denies women equality.

If we are persuaded that the fourteenth amendment's equality guarantee constrains legislative authority to regulate reproductive biology and that such laws raise issues different from those raised by laws that classify explicitly on the basis of sex, we must then consider what standard is appropriate for evaluating such laws. I propose that laws governing reproductive biology should be scrutinized by courts to ensure that (1) the law has no significant impact in perpetuating either the oppression of women or culturally imposed sex-role constraints on

${ }^{203}$ See supra notes $124-25$ and accompanying text. 
individual freedom or (2) if the law has this impact, it is justified as the best means of serving a compelling state purpose. Given how central state regulation of biology has been to the subjugation of women, the normal presumption of constitutionality is inappropriate and the state should bear the burden of justifying its rule in relation to either proposition.

This proposed test is a substantial improvement over current sex equality doctrine and the alternate approaches discussed above. Most fundamentally, the test recognizes that laws classifying according to biological differences raise equality concerns and must therefore be tested under equality norms. The test would also be consistent with a constitutional doctrine of sex equality grounded in the ERA-the test recognizes that the legislature may sometimes have legitimate reason to take account of biological reproductive difference, even if, as under an ERA standard, explicit sex-based classifications are prohibited. ${ }^{204}$

The test departs from contemporary equal protection analysis in that it does not require any comparison between allegedly similarly situated classes of people. This departure is appropriate because laws governing reproductive biology, by definition, govern ways in which men and women are not similarly situated. ${ }^{205}$ The requirement that similarly situated individuals be treated the same does not exhaust the idea of equality. ${ }^{206}$ Equality is a substantive goal, not simply a neat

204 The equality analysis advocated here is similar to that presented in Brown, ERA Article, supra note 19, in that it would scrutinize laws that classify based on biological differences differently than laws that establish explicit sex-based classifications. Like that article's analysis, the standard proposed here would demand "careful" scrutiny of laws based on biological differences. Id. at 958 .

Despite the formalistic similarity between the approach advocated here and that adopted in the ERA Article, I believe that the Yale analysis underestimates the problem that laws based on biological differences pose for sex equality.

See also Brown, ERA Article, supra note 19, at 909 ("Most of the objections which have been addressed to the absolute form of the Amendment are answered by the fact that the Amendment is inapplicable to laws dealing with unique physical characteristics of one sex or by application of the constitutional right of privacy."); id. at 961 ("Like rape, the definition of sodomy can be limited to penetration by the penis. Where sodomy is defined in this way, such that females are incapable of committing it, laws restricted to males may be sustained under the Equal Rights Amendment."); id. at 979 ("[The ERA] embodies a consistent theory that guarantees equal legal rights for both sexes while taking into account unique physical differences between the sexes."); supra text accompanying note 70 .

${ }^{205}$ Compare Fiss, Groups and the Equal Protection Clause, 5 PhiL. \& Pub. Afr. 107 (1976) and Gunther, The Supreme Court, 1971 Term-Foreword: In Search of Evolving Doctrine on a Changing Court: A Model for a Newer Equal Protection, 86 HaRv. L. Rev. 1 (1972) with Karst, The Supreme Court, 1976 Tern-Foreword: Equal Citizenship Under the Fourteenth Amendment, 91 HaRv. L. REv. 1 (1977) and Michelman, In Pursuit of Constitutional Welfare Rights: One View of Rawls' Theory of Justice, 121 U. PA. L. REv. 962 (1973).

${ }^{208}$ The animating purpose of the fourteenth amendment was to guarantee "the 
classification or a rational relationship between means and ends. Instead of evaluating the extent to which men and women differ in relation to a particular classification, the proposed test requries that a court consider the impact of the classification. This approach is similar to Professor MacKinnon's ${ }^{207}$ but it limits the direct inquiry into a law's effect upon perpetuating inequality to those cases in which that difficult inquiry is necessary to ensure that the law is consistent with the constitutional requirement of sex equality. ${ }^{208}$

The second part of the test is the compelling interest analysis. This strict scrutiny of the law is undertaken only after a court has determined that the law has a significant impact on perpetuating the inequality of women. Sometimes a law governing reproductive biology could be approved without a demonstration that it was the best means of serving a compelling state purpose, either because it had no discernable effect in oppressing women (for example, recordkeeping requirements) or because all of the effects we can discern are beneficial to women (for example, nutritional programs for pregnant women). But once we were convinced that a law governing reproductive biology oppressed women or perpetuated sex-role constraints, the state should bear the burden of justifying the law as the best means of serving a compelling state purpose. ${ }^{200}$ In race discrimination cases the requirement of compelling justification has been "strict" in theory and "fatal" in fact. ${ }^{210}$ This is not surprising given our broad cultural commitment to the assimilationist vision that explicit race classifications never accurately describe categorical differences. Since laws governing reproductive biology do accurately describe sex based differences, we should not

freedom of the slave race, the security and firm establishment of that freedom, and the protection of the newly-made freeman and citizen from the oppressions of those who had formerly exercised unlimited dominion over him." Slaughter-House Cases, 83 U.S. (16 Wall.) 36, 71 (1873).

${ }^{207}$ See supra notes $188-98$ and accompanying text.

${ }^{208}$ For a discussion of these types of cases, see infra part VI.

200 In proposing a "compelling" justification standard that is, in a formalistic sense, tougher than the standard articulated in Craig v. Boren, 429 U.S. 190 (1976) (explicit sex classifications must be closely related to important government interests), I do not necessarily mean to suggest that regulation of reproductive biology is a more serious obstacle to sex-based equality than explicit sex-based classifications. Although I believe that application of the compelling interest test in this context is most appropriate in light of equal protection analysis, I am skeptical whether the difference between a standard that demands that the state produce a "compelling" justification, and one that demands a showing of "close relation to important government interests" is outcome determinative. Burden of proof and good faith in the application of the verbal formula are the critical questions.

${ }_{210}$ Gunther, The Supreme Court, 1971 Term-Foreword: In Search of Evolving Doctrine on a Changing Court: A Model for a Newer Equal Protection, 86 HARv. L. REv. 1, 8 (1972). 
expect that a standard that demands a high level of justification will always be fatal in fact. Given the core importance of reproduction, laws recognizing reproductive biology might well be the best means of serving a compelling state purpose. But, once we have determined that a law governing reproductive biology oppresses women and perpetuates sex-role constraints on human liberty, it is essential to require that the state demonstrate very strong justification to support its action. The demand for compelling justification for such laws is supported by our history in which biology has been so central to the subjugation of women. ${ }^{211}$

The proposed two-level analysis also parallels the Supreme Court's contemporary reproductive freedom doctrine, which asks whether laws governing abortion restrict access to service and, if so, whether the legislation is supported by compelling state interests. ${ }^{212}$ This doctrine allows the states to adopt regulations-such as recordkeeping requirements-that do not impinge on access to services, without demanding that the state show compelling justification in support of such regulations. Similarly, the proposed test would subject regulations to strict scrutiny only when they restrict access to services because only those regulations have a significant impact in perpetuating oppression of women and sex role constraints. The proposed standard departs from the contemporary constitutional standard governing abortion laws in one important respect. In the abortion cases only protection of maternal health is recognized as a compelling state interest prior to fetal viability. ${ }^{213}$ The more general equality standard proposed here allows a compelling state interest to be established in relation to the broader substantive concerns of sex equality, including the oppression of women and the constraints of traditional sex roles.

Two criticisms of the approach advocated here deserve brief examination. First, in relation to laws governing reproductive biology, it suffers from the same inadequacies I have observed in Professor MacKinnon's suggestion that constitutional equality doctrine should ask simply whether a challenged policy or practice contributes to the oppression of women; that is, it is exceedingly difficult to determine what perpetuates sex-based deprivation, and standards that rely on judicial discretion are likely to provide weak protection. However, under the approach advocated here, the area of discretion is limited to laws governing reproductive biology; explicit sex-based classifications would continue to be eval-

211 See supra notes 13-14.

212 See, e.g., City of Akron v. Akron Center for Reproductive Health, Inc., 103 S. Ct. 2481, 2490-93 (1983).

213 See id. at 2490-93. 
uated under an arguably more reliable comparative standard. A second possible criticism of my suggested approach is that, while it requries that equality concerns be brought to bear on laws governing biological difference, it does not allow a legislature to use explicit sex-based classifications to recognize or reward traditional women's work or supposed female virtues that are not based in biological difference. Achieving increased social valuation of women and their traditional work is a critically important enterprise. But judicial enforcement of constitutional norms seems better suited to the more modest objective of formal comparative equality, with its relatively more reliable standards.

Finally, it is important to understand that my argument that the constitutional guarantee of equality requries that courts carefully scrutinize whether laws governing reproductive biology perpetuate stateimposed restraints on sex equality is not a claim that the state has an affirmative obligation to mitigate the effects of biological difference. Analysis of the question when the state may take affirmative action to remedy race- or sex-based disadvantage is beyond the scope of this Article. However, a clear distinction between laws using explicit sexbased classifications and those governing reproductive biology may be helpful in thinking about this issue. Affirmative action programs using explicit sex- or race-based classifications are justifiable in relation to the reality of historic oppression and the need for transitional measures to make equality of opportunity possible. ${ }^{214}$ But compensatory laws based explicitly on sex or race may perpetuate stereotypes of inferiority. ${ }^{215}$ Laws governing sex-specific physical characteristics, however,

214 See generally Wasserstrom, Topics, supra note 22 ("The State certainly has a legitimate and substantial interest in ameliorating, or eliminating where feasible, the disabling effect of identified discrimination."); Regents of the Univ. of Cal. v. Bakke, 438 U.S. 265, 307 (1978) (Powell, J.). Justice Blackmun, writing in support of the affirmative action program designed and instituted by the University of California to increase the numbers of minority medical students, said,

I yield to no one in my earnest hope that the time will come when an "affirmative action" program is unnecessary and is, in truth, only a relic of the past. I would hope that we could reach this stage within a decade at the most. But the story of Brown v. Board of Education, 437 U.S. 483 (1954), decided almost a quarter of a century ago, suggests that that hope is a slim one. At some time, however, beyond any period of what some would claim is only transitional inequality, the United States must and will reach a stage of maturity where action along this line is no longer necessary. Then persons will be regarded as persons, and discrimination of the type we address today will be an ugly feature of history that is instructive but that is behind us.

Id. at 403 (Blackmun, J., concurring in the judgment in part and dissenting in part). See also Fullilove v. Klutznick, 448 U.S. 448 (1980); United Steelworkers of Am. v. Weber, 443 U.S. 193 (1979).

${ }^{218}$ See Taub \& Schneider, supra note 118, at 134-35. The danger of reinforcing 
raise different issues. Special benefits for pregnant women, for example, ought to be analyzed in relation to the special needs of pregnant women, rather than as a means of providing compensation for past discrimination against women generally or pregnant women in particular. Laws governing sex-specific physical characteristics are not transitional measures enabling us to move toward sex-based equal opportunity in relation to reproductive capacity.

Now that a new approach to understanding the sex equality implications of laws that classify on the basis of biological differences has been outlined, the next part will apply the analysis to a variety of state laws related to abortion and pregnancy.

\section{Sex-Based Equality and Laws Governing REPRODUCTIVE BIOLOGY}

Applying the test developed in section IV to laws classifying on the basis of biological differences entails several inquiries. The threshold inquiry is whether the law makes a classification that is based on bio-

stereotypes may be greater in relation to sex-based classifications than in relation to race-based classifications because sex roles define appropriate ways of acting and being more comprehensively than race roles. Further sex-based classifications are especially invidious because they have often provided the protection and help of the pedestal that turns out to be a cage. No one ever defended chattel slavery as an institution adopted for the benefit of black people.

Nonetheless, the Court has approved compensatory sex-based classifications more readily than those based on race. Compare Califano v. Webster, 430 U.S. 313 (1977) and Galifano v. Goldfarb, 430 U.S. 199 (1977) (approving compensatory sex-based classifications) with Regents of the Univ. of Cal. v. Bakke, 438 U.S. 265 (1978).

Justice Powell, writing for himself in Bakke, asserted,

Gender-based distinctions are less likely to create the analytical and practical problems present in preferential programs premised on racial or ethnic criteria. With respect to gender there are only two possible classifications. The incidence of the burdens imposed by preferential classifications is clear. There are no rival groups which can claim that they, too, are entitled to preferential treatment .... The resolution of these same questions in the context of racial and ethnic preferences presents far more complex and intractable problems than gender-based classifications.

Id. at 302-03. He also stated that sex discrimination does not share the "lengthy and tragic history" of race discrimination. See id. at 303.

But in other contexts the Court has recognized the historic oppression of women. See, e.g., Kahn v. Shevin, 416 U.S. 351, 353 (1974) ("Whether from overt discrimination or from the socialization process of a male-dominated culture, the job market is inhospitable to the woman seeking any but the lowest paid jobs."). Discrimination against women has always been ostensibly benign, accomplished under the guise of protecting women either by compensating them for their physical frailties or or by making allowance for their special contributions to society. This reality may make it more, rather than less, difficult to evaluate whether sex-based protective laws hurt or help women seeking equality. See Gertner, Bakke on Affirmative Action for Women: Pedestal or Cage?, 14 HaRv. C.R.-G.L. L. Rev. 173 (1979). 
logical differences. As we saw in section $\mathrm{II},{ }^{216}$ this inquiry is not trivial-a law that implicates biological differences may actually be a categorical sex-based classification. ${ }^{217}$ If the law is found to be based on biological differences, the court must then consider whether the law has a substantial impact on perpetuating the inequality of women. If so, the court must engage in traditional strict scrutiny analysis to see whether the law is justified by a compelling state interest.

This part first applies the proposed test to laws restricting access to abortion. Such laws classify according to a sex-specific physical characteristic and have been central to enforcing the inferior status of women. ${ }^{218}$ The second section applies the proposed standard to a vari-

216 See supra notes 45-119 and accompanying text.

217 There is substantial evidence that the judiciary is not able to distinguish between biology and the social consequences attached to it. See generally supra part IV. In Dothard v. Rawlinson, 433 U.S. 321 (1977), the Court upheld an Alabama rule excluding women from the position of prison guard. Justice Stewart said,

The likelihood that inmates would assault a woman because she was a woman would pose a real threat not only to the victim of the assault but also to the basic control of the penitentiary and protection of its inmates and other security personnel. The employee's very womanhood would thus directly undermine her capacity to provide the security that is the essence of the correctional counselor's responsibility.

Id. at 336. A rule excluding women from positions in which they might be subject to rape is not a law governing a sex-specific physical characteristic or reproductive biology. Rather the Alabama policy, like that approved in Michael M., rests on the stereotype of male aggression and female vulnerability. Both men and women guards are vulnerable to assault, and indeed, to rape.

In Rostker v. Goldberg, 453 U.S. 57 (1981), the Court upheld male-only draft registration, relying on the syllogism that the purpose of registration is to raise combat troops and, since women are excluded from combat, it is therefore constitutional to register only men. The premise that it is permissible to exclude women from combat was not examined. See supra note 157. The assumption that men are fit for combat and women are not is both false and not based on sex-specific biology. See supra note 157.

A third example of judicial confusion between biology and the social consequences attached to it can be seen in the court cases rejecting the claims of same-sex couples who seek to marry. In Singer v. Hara, 11 Wash. App. 247, 522 P.2d 1187 (1974), the court characterized marriage as "the appropriate and desirable forum for procreation . . . . [which] exists as a protected legal institution primarily because of societal values associated with the propagation of the human race. . . [T] marriage . . . is founded upon the unique physical characteristics of the sexes." 11 Wash. App. at 259, 522 P.2d at 1195. Inasmuch as marriage is not an institution limited to people who are able to procreate, I believe this court erred in characterizing it as a law governing sex-specific physical characteristics or reproductive biology.

218 After the Givil War, many states and territories enacted criminal penalties for abortion. See Roe v. Wade, 410 U.S. 113, 139 (1973), and sources cited therein; see also L. Gordon, Women's Body, WOMEN's Right: A SOcial History OF BirTH Control in America (1976); J. MoHr, Abortion in America: The Origins and Evolution of National Policy, 1800-1900 at 200-25 (1978).

In Roe v. Wade, Justice Blackmun identified three justifications for the criminal abortion laws of the nineteenth century: "Victorian social concern to discourage illicit 


\section{ety of other laws that regulate according to biological differences.}

sexual conduct"; protection of the pregnant woman from medical procedures that "placed her life in serious jeopardy"; and finally, in a distinctly secondary role, protection of "prenatal life." 410 U.S. at 148-50. Gordon's and Mohr's work confirm and refine this historical analysis.

Victorian social mores did not, as Justice Blackmun suggested, simply condemn "illicit sexual conduct." Gordon demonstrates that, with the beginning of industrial capitalism in the first part of the nineteenth century, production drew men out of the home to socialized work places and undermined the economic basis of agrarian family unity. In reaction to this weakening of the economic basis of the traditional stability of the family structure, Victorian ideology arose to maintain family stability.

Victorian prudery was closely connected to the doctrine of a separate sphere of concerns for women. This notion that women were profoundly different from men . . . was simultaneously a description of a new reality: a male-imposed doctrine to keep women from escaping their homes and women's adaptation to their new situation.

L. GoRDoN, supra, at 18.

Some women had challenged these constraints. In 1848, the first recorded women's rights convention was held in Seneca Falls, New York. The Declaration of Sentiments, adopted at this convention, discussed discrimination against women in marriage, employment, education, criminal law, and the church. See 1 E. STANTON, S. ANTHONY \& M. Gage, History of Woman Suffrage 70-71 (1881). The next 20 years were, until the present, the most active period in the struggle for women's rights. Gordon's central thesis is that reaction to women's assertion of independence was a major factor motivating and justifying the enactment of criminal restrictions on abortion. See L. GoRdon, supra, at 414-18. Mohr agrees that this factor was important. See J. MoHR, supra, at 168.

In the late nineteenth century the types of women seeking abortion changed. Id. at 46-50, 86-102; L. GoRDON, supra, at 51-60. No longer were abortions sought solely because of illegitimacy or adultery; rather "respectable" women began to seek abortions to limit family size. J. MoHR, supra, at 86-102. Nineteenth century lobbyists for criminal restrictions on abortion expressed concern with the fact the birthrates were declining among the white, Yankee Protestants relative to Catholics and non-whites. Id. at 166-67. Gordon states,

Fears about immigrants and the poor reproducing faster than the Yankee elite had been current since before the Civil War. Physicians in particular noticed demographic patterns. Nathan Allen, a New England doctor, reported that in 1860 the foreign-born population of Massachusetts produced more children than the Yankees and that in 1877 a full 77 per cent of the births in all New England were Catholic. Another physician wrote that the birth rate was declining in "our most intelligent communities." Medical journals carried many similar articles of warning.

L. Gordon, supra, at 138 (footnotes omitted).

Finally, the medical profession was the major group lobbying for the restrictive abortion laws. It was, however, not simply that abortions were dangerous to the woman, but rather that abortions were generally performed by "irregulars": midwives, professional abortionists, empirical medics, herbalists, and other practitioners. The 1830's saw a blossoming of a popular health movement, dominated by women practitioners, particularly directed to women's health problems, and emphasizing education, nutrition, and self-reliance. Id. at 162-65; see also B. EHRENREICH \& D. ENGLISH, Witches, Midwives, and Nurses: A History of Women Healers 24-27 (1973). Mohr's central thesis is that the regular allopathic medical profession sought these restrictive laws to promote the authority of regular doctors and to restrict their irregular competitors. See J. MoHR, supra at 147-70. Gordon agrees. See L. GoRdon, supra, at 59-60. Mohr also argues that many physicians sincerely believed that abortion was 


\section{A. Abortion Restrictions and the Proposed Sex-Based Equality Analysis}

Abortion laws present no analytic difficulty for determining whether the classification is based on biological differences. The proposed analysis clearly applies to state regulation of abortion. Only women become pregnant; only women have abortions. Technology sometimes allows human beings to transcend the limits of biology. We fly. We visit Antarctica and space. Advances in human understanding, science, and medicine allow us to control reproductive capacity and to terminate a pregnancy at minimal risk to the health or future reproductive capacity of the woman. Nature demands that women alone bear the physical burdens of pregnancy, but society, through the law, can either mitigate or exaggerate the cost of these burdens. When the state denies women access to abortion, both nature and the state impose upon women burdens of unwanted pregnancy that men do not bear. ${ }^{219}$

The constitutional equality principle advocated here asks us to consider whether the state can meet the burden of proving that a law

wrong because of moral concerns about the fetus. See J. MoHR, supra, at 165 .

Prior to the development of antiseptic technique, abortion was extremely dangerous to the health of the woman, perhaps more dangerous than normal childbirth. But abortion was not then prohibited. At the historical moment when the development of antiseptic technique made it possible to do more good than harm through surgical procedures, abortion was prohibited. Compare P. Starr, The Social Transformation OF AMERICAN MEDICINE 156-57 (1982) (improvements in surgery) with J. MoHR, supra, at 200-25 (criminalization of abortion). This history strongly suggests that maternal health is not the primary issue at stake in the regulation of abortion.

218 Nineteenth century concepts of causation often sought a single cause for any phenomenon or a single human wrongdoer for any injury. See, e.g., Bohlen, Contributory Negligence, 21 HaRv. L. Rev. 233, 238 (1908); F. Wharton, A Treatise on THE LAW OF NEGLIGENCE $\S 139$ (1874). This approach to causation was functional in limiting liability and reinforcing individualist ideology. See Horowitz, The Doctrine of Objective Causation, in The Politics of LAw 201, 202 (D. Kairys ed. 1982). The twentieth century law normally recognizes that any phenomenon is the result of many concurring "causes" and that causation is probabilistic. See, e.g., W. PROsSER, ThE LAW OF TORTS $\S 43$ (4th ed. 1971).

More complex, sophisticated concepts of causation, which have come to dominate other areas of political and legal thought, often are not extended to sex-based biological difference. The assumption that biology causes women to bear the burdens of unwanted pregnancy is extremely functional, if somewhat simple-minded. In a related example of a simple-minded concept of causation, Justice Stewart asserted in Harris v. McRae, 448 U.S. 297, $316(1980)$, that "[t]he financial constraints that restrict an indigent woman's ability to enjoy the full range of constitutionally protected freedom of choice are the product not of governmental restrictions on access to abortions, but rather of her indigency."

President Jimmy Carter, defending the exclusion of abortion from the otherwise comprehensive Medicaid program, stated, "Life is unfair." N.Y. Times, July 13, 1977, $\S 1$, at 10 , col. 5 . Life may be unfair, but when the state excises the finding of abortions from Medicaid the state exacerbates the unfairness. 
governing reproductive biology either (1) has no significant impact in perpetuating the oppression of women or culturally imposed sex role constraints on individual freedom or (2) is the best means for meeting a compelling state purpose.

The burdens of unwanted pregnancy, which laws restricting abortion impose upon women, are enormous. First, such laws enforce the invasion of women's bodies. The physical burdens of pregnancy always include minor discomfort and physical intrusion and always pose risks of permanent damage to health and life itself that are vastly greater than the risks of abortion. ${ }^{220}$

Second, restricting access to abortion dramatically impairs the woman's capacity for individual self-determination. When the state prohibits abortion, all women of childbearing age know that pregnancy may violently alter their lives at any time. ${ }^{221}$ This pervasively affects the ability of women to plan their lives, to sustain relationships with other people, and to contribute through wage work and public life. The right to equal citizenship encompasses the right "to take responsibility for choosing one's own future. ... . [T]o be a person is to respect one's own ability to make responsible choices in controlling one's own destiny, to be an active participant in society rather than an object."222 Denying abortion denies women the capacity of responsible citizenship.

Third, the decision of whether or not to bear a child is inescapably a complex moral and practical one, requiring consideration of relations with existing people and one's capacity to care for the child or to find others who will do so. Bearing a child creates a profoundly intimate relationship between the woman and the child, even when that rela-

220 The risks of death or serious complications are at least seven times greater in childbirth than in first trimester abortion. Cates, Smith, Rochat \& Grimes, Mortality From Abortion and Childbirth: Are the Statistics Biased?, 248 J. A.M.A. 192 (1982); LeBolt, Grimes \& Cates, Mortality From Abortion and Childbirth: Are the Populations Comparable?, 248 J. A.M.A. 188 (1982). The health risks of pregnancy and childbirth are greatly exacerbated when a pregnancy is unwanted. Cates, Legal Abortion: The Public Health Record, 215 Sci. 1586, 1587 (1982).

231 Every fertile woman is vulnerable to the risk of an unwanted pregnancy resulting from rape. See supra note 178 . The risks of unwanted pregnancy fall most heavily on sexually active heterosexual women. All methods of contraception are imperfect; the methods that are most effective in preventing pregnancy pose the greatest danger to the woman's health. Women using various methods of contraception run the following risks of unintended pregnancy each year: oral contraceptives, $2.4 \%$; IUD, 4.6\%; condom, 9.6\%; diaphragm, 18.6\%; foam, 17.9\%; rhythm, 23.7\%. Schrim, Trussell, Menken \& Grady, Contraceptive Failure In the United States: The Impact of Social, Economic and Demographic Factors, 14 Fam. Plan. Persp. 68 (1982).

${ }^{222}$ Karst, The Supreme Court 1976 Term, Foreword: Equal Citizenship Under the Fourteenth Amendment, 91 HARv. L. REv. 1, 58 (1977). Karst notes that " $[\mathrm{t}]$ he abortion question was not merely a 'women versus fetuses' issue; it was also a feminist issue, an issue going to women's position in society." Id. 
tionship ends shortly after birth. ${ }^{223}$ For many women who attempt to live in accordance with mainstream Protestant and Jewish faith, religious belief informs the decision whether to bear a child. ${ }^{224}$ For other

${ }^{223}$ Although two-thirds of births to unmarried teenagers are unintended, few teenage mothers place babies for adoption or for care by friends or relatives. Ninety-six percent of unmarried teenage mothers-90\% of white and virtually all of black mothers-keep their children. Alan Guttmacher Institute, Teenage PregNancy: The Problem that Hasn't Gone Away (1981).

224 Mainstream Protestants believe that the Bible, as interpreted through the person of Jesus Christ, imposes a duty on individuals to make deliberate decisions about childbearing, according to principles of responsible parenthood. Rev. John Philip Wagaman, Dean and Professor of Christian Social Ethics at Wesley Theological Seminary and past president of the American Society of Christian Ethics, explains that "nearly no aspect of life is more sacred, closer to being human in relation to God, than bringing a new life into the world to share in the gift of God's grace and God's covenant." McRae v. Califano, 491 F. Supp. 630, 700 (E.D.N.Y.), rev'd sub. nom. Harris v. McRae, 448 U.S. 297 (1980). The question is whether one "is bringing a life into the world under conditions which make it possible for that life to participate in God's intention ... (and under conditions which will not) threaten to undermine the theologically understood fulfillment of already existing human beings." Id. at 700-01. Although in Protestant teaching the basic judgment whether to bear a child is "referred to the woman and her own religious conscience," there are circumstances in which abortion may be "mandatory as a person's responsibility before God." Id. at 702.

Protestant theology does not regard the fetus as a person "until that stage in development where someone has begun experience of reality." This view flows from "the covenant [that] subsists between God as the Creator of reality and those who have begun to experience the reality which God has created." Id. at 701.

Professor Beverly Harrison explains this pro-choice theology:

We encounter God through relationship with all that nurtures and sustains life. . . Freedom, when understood as the power of creativity, achieves its consummate expression in deepened community. . . . To be free means possessing the power to imaginatively interact with others, to give and to receive, to act upon and to suffer (that is, to be acted upon), to participate with others in co-creating a world. ... God is not the one who stands remotely in control, but the One who binds us and bids us to deep relationality, resulting in a radical equality motivated by genuine mutuality and interdependence.

B. Harrison, Our Right to Ghoose, Toward a New Ethic of Abortion 99, 100,108 (1983). In this view "the moral life involves a process of selecting and integrating many potential values through strategic choices." $I d$. at 110 . The decision to have an abortion or a child requires consideration of relations with existing people, as well as assessment of capacity to provide care for the child.

The second theme of pro-choice theology focuses on the health of the mother. Jewish thought places a high value on the individual obligation to protect her own health. The Biblical injunction, "Therefore, choose life," refers not to the everlasting life promised to Christians through baptism and faith, but to life in this world. As Rabbi David Feldman explains, "[W]hen a woman's life or health is threatened . . . abortion . . becomes mandatory." Abortion is "appropriate" since "the duty is to choose life." McRae, 491 F. Supp. at 696 (testimony of Rabbi David Feldman). Rabbi Feldman's views are also set forth in Marital Relations, Contraception, and Abortion (1976).

In Jewish thought the fetus is not a person until it "emerges from the womb into the world, or, more exactly until the head of the infant emerges, or, in the case of a breach birth, half of the body emerges." McRae, 491 F. Supp. at 697 . The abortion 
women who are not formally religious, the choice is a conscientious one. ${ }^{225}$ By restricting access to abortion, the state necessarily denies the capacity of women as independent moral decisionmakers. ${ }^{226}$

Finally, state action restricting access to abortion imposes a crushing restraint on the heterosexual women's capacity for sexual expression. ${ }^{227}$ At the heart of Sigmund Freud's central innovation in modern thought is his recognition of the pervasive imaginative force of sexuality in the life of human beings. ${ }^{228}$ For humans, sexual relations are invaluable expressions of love and bonding that strengthen the intimate relationships that give life meaning. ${ }^{229}$ More than one hundred years after Freud "it is depressing to have to insist that sex is not an unnecessary, morally dubious self-indulgence, but a basic human need, no less for

decision is nonetheless a serious moral matter because it involves potential human life. There are sharp divisions in Jewish thought, with Orthodox Jews and some Conservatives holding that only the most serious threats to a woman's life justify abortion, while those in the Reform tradition embrace a broader definition of health, holding that the primary concern is the welfare of the mother and the final decision is the woman's. Id.

${ }^{225}$ Conceding that restrictions on abortion impose enormous burdens upon women, it might be argued that the burdens are comparable to those imposed upon people subject to the draft and that the state is free to impose burdens on citizens in furtherance of legislative judgments about morality and public policy. Because Congress provides conscientious objectors statutory exemption from military service, the Court has not confronted the question whether such exemption is constitutionally required. However, the Court has construed the apparently theistic statutory language to extend exemption to those who hold a sincere belief occupying "a place in the life of its possessor parallel to the filled by the orthodox belief in God of one who clearly qualifies for the exemption." United States v. Seeger, 380 U.S. 163, 166 (1965). See Welsh v. United States, 398 U.S. 333 (1970); see also Thomas v. Review Bd., Ind. Employment Sec. Div., 450 U.S. 707 (1981) (upholding a similar objection by a Jehovah's witness to working on the production of weaponry).

226 See generally C. Gilligan, supra note 23, at 64-105.

${ }^{227}$ See, e.g., Doe v. Commonwealth's Attorney, 425 U.S. 901 (1976), affirming

403 F. Supp. 1199 (E.D. Va. 1975).

Thomas Gray observes that the contraception and abortion cases employ rhetoric "dedicated to the cause of social stability through the reinforcement of traditional institutions and have nothing to do with the sexual liberation of the individual. They represent two standard conservative views: social stability is threatened by excessive population growth, and family stability is threatened by unwanted pregnancies." Gray, Eros, Civilization and the Burger Court, 43 Law \& ConTemp. PROBS. 83, 88 (1980). See also Eichbaum, Towards an Autonomy-Based Theory of Constitutional Privacy: Bejond the Ideology of Familial Privacy, 14 Harv. C.R.-C.L. L. REv. 361 (1979).

The equality analysis presented here does not directly address the problem of constitutional protection for sexual expression. However, insofar as the law has traditionally enforced a sexual double standard respecting the sexual autonomy of heterosexual men while denying the legitimacy of female and male homosexuality, equality analysis may be an important component of a more general right to sexual expression. There is a deep, complex interrelationship between sexist and homophobic attitudes in a patriarchal society. Full exploration of these relationships is beyond the scope of this Article. 228 Freud, "Civilized" Sexual Morality and Modern Nervous Illness, in 9 THE Complete Psychological Works of Sigmund Freud 181 (standard ed. 1908).

229 I. Eibl-Eibesfeldt, Love AND Hate 155-64 (1972). 
women than for men."230

State restrictions on access to abortion plainly oppress women. Roe v. Wade $e^{\mathbf{2 3 1}}$ condemns such laws as a violation of the constitutional right to privacy. The rhetoric of privacy, as opposed to equality, blunts our ability to focus on the fact that it is women who are oppressed when abortion is denied. A privacy right that demands that "the abortion decision . . . be left to the medical judgment of the pregnant woman's attending physician," ${ }^{232}$ gives doctors undue power by falsely casting the abortion decision as primarily a medical question. ${ }^{233}$ The rhetoric of privacy also reinforces a public/private dicotomy that is at the heart of the structures that perpetuate the powerlessness of women. ${ }^{234}$

Although laws restricting access to abortion plainly oppress women, the standard proposed here would allow the oppressive restriction of access to abortions if the law withstood strict scrutiny. Considering the regulation of access to abortion under privacy doctrine, rather than sex equality doctrine, does not make it easier to address the difficult question of whether the state has a compelling justification for re-

230 Willis, Abortion: Is a Woman a Person?, in Powers of DesIRE, supra note 34 , at 471,474 .

231 U10 U.S. 113 (1973).

232 Id. at 164.

2ss The woman's attitude toward her pregnancy is the most important factor in determining whether or not an abortion is medically indicated. There are virtually no situations in which a physician would recommend an abortion to a woman who sought to continue the pregnancy and who was able to cooperate in doing so. On the other hand, the very fact that the pregnancy is unwanted produces intense stress, which exacerbates a variety of conditions, making them life and health threatening. See McRae v. Califano, 491 F. Supp. 630, 664-90 (E.D.N.Y. 1980), rev'd sub. nom. Harris v. McRae, 448 U.S. 297 (1980).

In every state it is a crime for anyone other than a doctor to perform an abortion, and the constitutionality of such requirements has been affirmed. See Connecticut v. Menillo, 423 U.S. 9 (1975). Yet abortion is not a technically complex procedure. Midwives, nurse practitioners, and other nonphysician health care providers deliver babies and provide a variety of other services that are as medically complex as first trimester abortions. See Donovan, Medical Societies vs. Nurse Practitioners, 15 Fam. Plan. Persp. 166 (1983); see also Asaro, The Judicial Portrayal of the Physician in Abortion and Sterilization Decisions: The Use and Abuse of Medical Discretion, 6 Harv. Women's L.J. 51 (1983).

${ }^{234}$ Kathleen Powers observes,

By maintaining a world split into public and private spheres, by denying women the right to participate in the public sphere and then refusing to regulate the private sphere or deferring to custom when compelled to regulate that sphere, the legal order effectively excluded women from its operations and constrained women to exist in a pre-modern world of customary law, a world where personal conduct was determined by patterns of custom and reciprocal expectations and where the distinction between habit and duty became blurred and ill defined.

Powers, Sex Segregation and the Ambivalent Directions of Sex Discrimination Law, 1979 Wis. L. REv. 55, 78. See also Olsen, supra note 4. 
stricting women's access to abortion. The only reason seriously advanced for restricting abortion today, and the only one that could possibly justify the oppression of women under a strict scrutiny analysis, is protection of fetal life. ${ }^{236}$ The abortion debate is often cast as a conflict between the rights of a woman and those of a fetus. ${ }^{236}$ Opponents of abortion characterize it as murder. Neither equality nor privacy can support an asserted right to murder.

But, even if we regard the fetus as a person, it does not necessarily follow that abortion is murder. It is "impossible to judge whether an act is murder simply by looking at the act, without considering its context."237 Ellen Willis argues that we can assume that the fetus is a person and yet support a woman's right to choose abortion as a form of self defense.

[N]o thoughtful pacifist would equate Hitler's murder of the Jews with the Warsaw Ghetto rebels' killing of Nazi troops. . . However gratifying pregnancy may be to a woman who desires it, for the unwilling it is literally an invasion-the closest analogy is the difference between lovemaking and rape. ... [A]bortion is by normal standards an act of self-defense. ${ }^{238}$

Similarly, Donald Regan argues that even if we think of the fetus as a person, evenhanded application of the general common law principle that people are not required to aid others, particularly when aid can only be provided at significant cost and risk to the rescuer, demands respect for the woman's right to refuse to aid the fetus. ${ }^{239}$

295 See L. Summner, Abortion and Moral Theory 23-24 (1981).

${ }^{238}$ For example, John Ely observes, "Compared with men, very few women sit in our legislatures, a fact I believe should bear some relevance-even without an Equal Rights Amendment-to the appropriate standard of review for legislation that favors men over women. But no fetuses sit in our legislatures." Ely, The Wages of Crying Wolf: A Comment on Roe v. Wade, 82 Yale L.J. 920, 933 (1973).

Professor Ely misapprehends the nature of the fetus. The traditional formulation of a rights conflict between the woman and the fetus

is based on a mistaken parallel between adult life and fetal life. Once we understand how the special circumstances of pregnancy affect a fetus's right to life, we see the problem of abortion in a new light-as a moral issue of care, nurture, and responsibility, rather than a conflict of rights between woman and fetus.

Farrell-Smith, Rights-Conflict, Pregnancy, and Abortion, in BEYOND

Domination 265 (G. Gould ed. 1983).

${ }^{237}$ Willis, supra note 230 , at 473 .

$258 I d$.

2s9 Regan, in Rewriting Roe v. Wade, 77 Mich. L. REv. 1569 (1979), argues that restricting access to abortion denies equal protection of the law, not because it discriminates on the basis of sex, but rather because it excludes pregnant women from 
The strengths of these formulations are that they come squarely to grips with the assertion that the state has an interest in protecting the fetus, ${ }^{240}$ and they recognize the magnitude of the injury inflicted upon women who are forced to continue an unwanted pregnancy. But these justifications for abortion are disquieting. Regan defends abortion on the same grounds we might support the legal right to refuse to throw a rope to a drowning child-as an action that is morally wrong but legally protected. Willis's self-defense formulation is equally troubling. The legalistic analogy to self-defense justifies abortion only in the limited circumstances in which the mother reasonably believes that she will suffer death or great bodily harm. ${ }^{241}$ Further, even if it is legally justifiable to kill an innocent person who threatens our life or wellbeing, the morality of such killing seems dubious. Thus both Regan and Willis characterize abortion as a conflict between the rights of the woman and the rights of the fetus. Both treat the fetus as a person and

the protection of the "deeply rooted principle of American law that an individual is ordinarily not required to volunteer aid to another individual who is in danger or in need of assistance." Id. at 1569. Individual interests in physical integrity and nonsubordination, recognized by the common law no-duty-to-aid principle, are also constitutionally protected by the thirteenth amendment's prohibition of involuntary servitude and the eighth amendment's ban on cruel and unusual punishment. On the constitutional protection of physical integrity, see Estelle v. Gamble, 429 U.S. 97, 102-03 (1976) (denial of medical treatment for prisoners is a violation of the eighth amendment); Rochin v. California, 342 U.S. 165 (1952) (pumping the stomach of a suspect is a violation of due process). On the constitutional value of non-subordination, see Taylor v. Georgia, 315 U.S. 25 (1942) (peonage is violation of thirteenth amendment); Bailey v. Alabama, 219 U.S. 219, 241 (1911) (involuntary servitude encompasses more than slavery).

Regan argues that, even if we hypothesize that the fetus is a full human being, the equality guarantee nonetheless prohibits the state from singling out pregnant women and demanding that these individuals sacrifice their physical integrity to aid a person in need.

[C]onsider a simple burning building, with a child trapped inside. Would a court impose criminal liability on anyone, even the child's parent, who did not attempt to save the child at the risk of second-degree burns over one or two percent of his or her body? . . .

[A]n innocent life can be saved by a physical invasion comparable to or less than pregnancy and delivery. ... [E]ven if the potential rescuer is specified to be the child's parent, liability is unlikely. In all other cases, the suggested imposition is unthinkable in the context of our legal system.

Regan, supra, at 1588 . Those who have advocated a legal duty to rescue would limit the duty to situations in which rescue can be effected without significant cost or physical risk to the rescuer. See, e.g., Ames, Law and Morals, 22 HARv. L. Rev. 97, 111-13 (1908); Franklin, Vernont Requires Rescue: A Comment, 25 STAN. L. REv. 51 (1972); Weinrib, The Case for a Duty to Rescue, 90 YALE L.J. 247 (1980); see also Rudolph, The Duty to Act: A Proposed Rule, 44 NEB. L. REv. 499 (1965).

240 But see, e.g., Heymann \& Barzelay, The Forest and the Trees: Roe v. Wade and its Critics, 53 B.U.L. REv. 765, 773 (1973) (decisions in the area of privacy are not easily controlled by the state).

241 See generally W. Prosser, supra note 219, at 108-12 (on self-defense). 
defend abortion by analogy to circumstances in which injury to or neglect of a person would be legally, if not morally, justifiable.

The view that abortion is morally suspect is inconsistent with significant currents of moral thought. ${ }^{242} \mathrm{~A}$ stronger defense of abortion rights must not simply assume that the fetus is a person but must rather directly challenge the claim that the legislature may declare fetal life to be personhood or, in the face of uncertainty, may require that the fetus be treated as a person.

Fetal life is starkly different from all other forms of human life in that the fetus is completely dependent upon the body of the woman who conceived it. It cannot survive without her. Although all human infants, and many adults, are dependent upon others for survival, that support can be provided by many people. The fetus by contrast is dependent upon a particular woman. "For a fetus, the conditions of life are such that one other human being, the pregnant woman, is in a unique position of being able to respond to its alleged right to life."24s No other human being is in such a relationship with other humans.

This distinguishing characteristic of fetal life supports the line that Roe v. Wade draws between the woman's right to decide whether to abort and the state's power to protect fetal life. ${ }^{244}$ It is only after birth that anyone other than the mother can assume responsibility for the nurture that is indispensible to life. At the point of viability, ${ }^{245}$ when

242 See supra note 224.

248 Farrell-Smith, supra note 236, at 267. See also Fletcher, Abortion, Euthanasia, and the Care of Defective Newborns, 292 New ENG. J. of MEDICINE 75 (1975) (arguing that the fetal dependence upon a particular woman makes abortion morally distinct from euthanasia of defective infants).

244410 U.S. at 163.

24s Justice O'Connor, dissenting in City of Akron v. Akron Center for Reproductive Health, 103 S. Ct. 2481 (1983) asserted that, "[t]he Roe framework, then, is clearly on a collision course with itself . . . . As medical science becomes better able to provide for the separate existence of the fetus, the point of viability is moved further back toward conception." Id. at 2507. She noted that "recent studies have demonstrated increasingly earlier fetal viability. ${ }^{5}$ It is certainly reasonable to believe that fetal viability in the first trimester of pregnancy may be possible in the not too distant future." Id.

The evidence offered in Justice O'Connor's footnote 5 does not support her claims. She cites Phillips, Little, Polivy \& Lucey, Neonatal Mortality Risk for the Eighties: The Importance of Birth Weight/Gestational Age Groups, 68 Pediatrics 122 (1981), for the proposition that infants "with a gestational age of less than 25 weeks and weight between 500 and 1,249 grams have a $20 \%$ chance of survival." 103 S. Ct. 2507 n.5. In fact, the data presented shows that of 523 premature infants treated in a regional intensive care unit between 1976 and 1979, five were 25 weeks or less gestational age. Two of these babies weighed between 500 and 749 grams and both died; one baby weighed between 750 and 999 grams and it died; two babies weighed between 1,000 and 1,249 grams and one survived. See id. at 125 table 4. O'Connor observes ominously, "The aborted fetus in. . Simopoulos $v$. Virginia . . . . weighed 495 grams and was approximately 22 gestational weeks." 103 S. Ct. 2507, n.5.

In support of the claim that fetal viability may soon be possible in the first trimes- 
the fetus "has the capability of meaningful life outside the mother's womb,"246 the state may restrict abortions, except where the life or health of the mother would be endangered if the fetus were carried to term. ${ }^{247}$

ter, Justice O'Connor also cites Kopelman, The Smallest Pretern Infants: Reasons for Optimism and New Dilemmas, 132 AM. J. Diseases ChILdRen 461 (1978). Dr. Kopelman, Head of Neonatology at East Carolina School of Medicine, comments,

I would respond emphatically that my article does not in any way, shape or form support such a contention. Furthermore I know of no current research which would lead me to believe that a fetus of less than 22 weeks gestation can be or soon will be able to be sustained outside the uterus. ... .

Below 24 weeks gestation the fetus' lungs are simply not adequately developed to sustain oxygenation even with ventilator support.

Letter to Nan Hunter, Sept. 12, 1983 (copy on file with the University of Pennsylvania Law Review)

Finally Justice O'Connor cites Stern, Intensive Care for the Pre-Term Infant, 26 Danish med. Bull. 144 (1979). Dr. Stern, Professor \& Chairman of Pediatrics at Brown University, responds,

It may well be that some of the other references quoted in the footnote have demonstrated "increasingly earlier fetal viability," but that is certainly not what I said in my article . . . [i]t is highly likely that the lower limit beyond which human gestation is simply incapable of survival has already been virtually reached in its entirety, at least insofar as we intend such survival to be possible without the intervention of some form of artificial extrauterine environment that could be provided by the successful creation of an artificial placenta.

Letter to Nan Hunter, Aug. 3, 1983 (copy on file with University of Pennsylvania Law Review). After discussing the "extreme technical difficulties" in creating substitutes for a woman's womb, Dr. Stern observes,

Even if such a procedure could be successfully achieved, not only are its economic costs staggering to imagine but the potential for ever being able to supply the technology in sufficiently large numbers of units to make any kind of impact on the total number of threatened or spontaneously terminated first trimester gestations would be in practical terms most unlikely.

Id. In short, the evidence does not support Justice O'Connor's claims in relation to fetal viability.

Viability is a probabalistic concept that refers to the probability that a fetus has approximately a a $10 \%$ chance of survival outside the womb. See Colantti v. Franklin, 439 U.S. 379, 396, n.15 (1979). The probability of survival is affected by gestational age, fetal weight, general maternal nutrition, and the technological resources available. It is difficult to make a precise determination of gestational age even after the birth of a premature infant. Dubowitz, Dubowitz \& Goldberg, Clinical Assessment of Gestational Age in the Newbom Infant, 77 J. Pediatr. 1 (1970). It is even more difficult to estimate gestational age or weight in utero. Because of the inherent difficulty and uncertainty of estimating viability, the Supreme Court has held that states must "afford the physician adequate discretion in the exercise of his medical judgment." Colantti v. Franklin, 439 U.S. at 387.

${ }^{246}$ Roe v. Wade, 410 U.S. at 163.

${ }^{247}$ As Roe v. Wade recognizes, the fact that a fetus has some probability of survival outside of the womb does not necessarily justify state action forcing the woman to continue to support it. See Frost, Chudwin \& Wikler, The Limited Moral Significance 
Thus, the compelling state interest analysis leads one to conclude that once the fetus has reached the point of viability the state may restrict the availability of abortions, except in cases where the life or health of the mother would be endangered if the fetus were carried on to term. Notwithstanding this understanding of the nature of fetal life and the related strict scrutiny of the government's interest, three powerful ideas continue to fuel the effort to criminalize abortions. I believe that none of these ideas could provide the state with an interest compelling enough to justify any additional limits on access to abortions.

First, many people sincerely believe that a human being exists from the moment of conception. ${ }^{248}$ But as Professor Laurence Tribe observes,

of Fetal Viability, Hastings Center Rep., Dec. 1980, at 10, 13.

As a practical matter, few abortions are performed near the point of potential fetal viability. In 1976, 95\% of abortions were performed prior to 15 weeks gestation. See McRae v. Galifano, 491 F. Supp. 630, 635 (E.D.N.Y.) (presenting data from the U.S. Center for Disease Control), rev'd sub. nom. Harris v. McRae, 448 U.S. 297 (1980). Less than $1 \%$ of abortions are performed for women who are more than 21 weeks pregnant. N.Y. Times, Feb. 15, 1984, at B-1, B-4, col. 1.

Late term abortions are most commonly performed for girls between ages of 15 and 19, who are slow to realize or acknowledge that they are pregnant and who often have difficulty in obtaining medical services. Ten per cent of abortions performed after the end of the first trimester are done for women who have amniocentesis and discover that the fetus is genetically abnormal. Id. Testing to discover genetic defects in utero cannot be completed until after 18 to 20 weeks gestation. Colantti v. Franklin, 439 U.S. 379,389 , n.8 (1979). A third group of late abortions involve women who contract a disease during pregnancy that poses a risk to their life or health or that damages the fetus. McRae, 491 F. Supp. at $678-80$.

${ }^{248}$ For the Roman Catholic Church, the largest denomination condemning abortion, opposition is grounded on the belief that a human being exists at the moment of fertilization. Any uncertainty as to the precise moment of "ensoulment" must be resolved in favor of the fetus, in part because the concept of original sin means that unborn life is perfect, born life imperfect. McRae v. Califano, 491 F. Supp. 630, 69293 (E.D.N.Y.) (testimony of Reverend William B. Smith), rev'd sub. nom. Harris v. McRae, 448 U.S. 297 (1980). The Declaration on Abortion of the Sacred Congregation for the Doctrine of the Faith is "the Church's most definitive and authoritative statement on the morality of direct abortion." See id. at 693. Catholic teaching distinguishes "indirect" abortion, that is, "operations, treatments and medications which do not directly intend termination of pregnancy, but which have as their purpose the cure of a proportionately serious pathological condition of the mother . . . when they cannot be safely postponed until the fetus is viable." Id. at 694 (quoting from the 1971 Ethical and religious Directives for Catholic Health Facilities).

Catholic doctrine also regards contraception as a form of homicide. Contraception was treated differently from abortion for the first time in the Second Vatican Council's Declaration on The Church in the Modern World. Noonan, An Almost Absolute Value in History, in The Morality of ABorTION 45-46 (J.T. Noonan ed. 1970). The distinction was shortlived for, in 1967, the Minority Report of the Papal Panel on Birth Control, which Pope Paul VI accepted as the basis for his 1968 encyclical Humanae Vitae, described contraception as "analogous to homocide." See N. ST. John-Stevas, The Agonising Choice 254 (1971), for the view of one Catholic intellectual protesting the equation of abortion and contraception. 
[T] he question when human life truly begins asks not for a discovery of the point at which the fetus possesses an agreedupon set of characteristics which make it human, but rather for a decision as to what characteristics should be regarded as defining a human being. And ... that decision in turn entails not an inference or demonstration from generally shared premises, whether factual or moral, but a statement of religious faith upon which people will invariably differ widely. ${ }^{249}$

In a pluralistic society, ${ }^{250}$ religious belief cannot, by itself, justify a law imposing oppressive sex discriminatory burdens and demanding that

218 Tribe, The Supreme Court 1972 Term, Foreword: Toward a Model of Roles in the Due Process of Life and Law, 87 HARv. L. REv. 1, 21 (1973) (citations omitted). Tribe subsequently repudiated this position:

[O]n reflection, that view appears to give too little weight to the value of allowing religious groups freely to express their convictions in the political process, underestimates the power of moral convictions unattached to religious beliefs on this issue, and makes the unrealistic assumption that a constitutional ruling could somehow dissentangle religion from future public debate on the question.

\section{Tribe, American Constitutional Law $\S 15-10$, at 928 (1978).}

Tribe's grounds for rejecting his earlier views are not persuasive. No one challenges the right of religious groups to "express their convictions in the political process." The first amendment protects advocacy of racism and the natural subordination of women and fetal rights, and it protects advocacy doubly when the views promoted are religiously based. See McDaniel v. Paty, 435 U.S. 618 (1978) (state constitution that disqualifies ministers from serving as legislators violates "free exercise of religion" clause). There are undoubtedly people opposed to abortion on grounds of "moral conviction unattached to religious beliefs." For cases stating that the government cannot favor any religion or religion over nonreligion, see Epperson v. Arkansas, 393 U.S. 97 (1968); Abington School Dist. v. Schempp, 374 U.S. 203 (1963); Engel v. Vitale, 370 U.S. 421 (1962). But where moral values are in such sharp conflict, the first amendment requires respect for diversity.

250 The anti-choice theologies are explicitly anti-pluralist. The self-proclaimed "moral majority" asserts that "[a]fter the Christian majority takes control, pluralism will be seen as immoral and evil and the state will not permit anybody the right to practice evil." Gary Potter, President, Catholics for Political Action, quoted in Greene, The Astonishing Wrongs of the New Moral Right, Playboy, Jan. 1981, at 118.

Some Catholics ethicists, while adhering to belief that the personhood of the fetus makes abortion a grave sin, oppose use of state power to restrict access to abortion because of respect for individual human freedom in a pluralistic society. Paper by Charles Curran, Professor of Moral Theology, Catholic University of America, presented at NYU Symposium on Abortion and the First Amendment (April, 1980) (copy on file with the University of Pennsylvania Law Review). Although this view has not yet prevailed with the Church, "it may be a harbinger of cracks in the seemingly monolithic Catholic position on abortion funding that a few prominent Catholic intellectuals do dissent." F. JAFFe, B. LINDHEIM \& P. LEE, ABORTION Polrtics 178-79 (1981). Legislative struggles over anti-contraception laws ended when, in the mid1960 's, many prominent Catholics of high moral and intellectual stature openly opposed efforts of the institutional Church to use public law to enforce natural law doctrine condemning birth control. Id. at 175-77. 
others sacrifice their own deeply held conscientious beliefs. ${ }^{251}$

Second, the right to life movement, as its name implies, aspires to promote an expanded respect and protection for all forms of human life. People who are dependent-infants, the poor, the elderly, and the disabled-make a strong moral claim on the resources of a society of abundance. Social values of helping and nurture are profoundly important. ${ }^{252}$ But the sustenance the fetus needs is not society's to give. It can only be provided by a particular pregnant woman. Forcing her to support the dependent fetus denies her capacity to decide whether that is a relationship that she can sustain and imposes enormous costs on her life, health, and autonomy. Respect for the fetus is purchased at the cost of denying the value of women. ${ }^{25 s}$

251 Governmental support of a particular religious belief is not only an undesirable result but is prohibited by the Constitution, see supra note 249 . "[A] broader establishment clause issue, going to a whole area of governmental regulation, is raised whenever the views of organized religious groups have come to play a pervasive role in an entire subject's legislative consideration for reasons intrinsic to the subject matter as then understood." Tribe, supra note 249 , at 23 (footnote omitted).

252 As we have seen, the assumption that mothers will choose to assume responsibility for the care necessary to the survival of infants is so ingrained that even thoughtful people cannot perceive that women nurture by choice, rather than as a result of biological imperative. See supra notes 146-61 and accompanying text. It is obviously critically important to children, and to society, that someone assume responsibility for the care of infants.

Often, those who support a woman's authority to decide whether a bear a child rely upon the undeniable fact that in this society women choose or are compelled to care for their children after birth. For example, Ellen Willis argues,

We live in a society that defines childbearing as the mother's job; a society in which most women are denied access to work that pays enough to support a family, childcare facilities they can afford, or any relief from the constant, daily burdens of motherhood; a society that forces mothers into dependence on marriage or welfare and often into permanent poverty; a society that is actively hostile to women's ambitions for a better life.

Willis, supra note 230 , at 473 . The Supreme Court observes,

[A]dditional offspring may force upon the woman a distressful life and future. . . Mental and physical health may be taxed by child care. There is also the distress, for all concerned, associated with the unwanted child, and there is the problem of bringing a child into a family already unable, psychologically and otherwise, to care for it.

Roe, 410 U.S. at 153.

In defending a woman's right to decide whether to bear a child, I have not relied upon the social reality that women care for children. That is simply a social arrangement that we could choose to alter. Petchesky, Reproductive Freedom: Beyond "A Woman's Right to Choose," 5 Signs: J. Women in GulruRe \& Soc'y 661 (1980), thoughtfully explores the questions whether there is a conflict between the individualistic "right to choose" and a more connected, caring social vision. She concludes, as do I, that "control over one's body is a fundamental . . . requirement of being a person and engaging in conscious activity. Understood thus, it is a principle of a radical morality that should never be abandoned, under any social conditions." Id. at 666 .

${ }^{253}$ Professor Tribe argues against policies giving men a right to veto abortion choice and discusses, in moving terms, the sex differential aspect of denying access to 
Finally, the drive to criminalize abortion is animated by an affirmation of the value of a patriarchal society. Many people believe, as a matter of revealed faith or experience, that women are and should be subordinate to men, that sex should be limited to procreation, and that the risk of unwanted pregnancy should function to discourage sex and to bind families together. ${ }^{254}$ But application of the constitutional ideal of equality to men and women prohibits the state from using its coercive power to enforce patriarchal relations.

Control of reproduction is the sine qua non of women's capacity to live as equal people. The high place of equality in our constellation of democratic and constitutional values demands that something more compelling than traditionalist moral conviction justify state actions denying women that which is indispensibly necessary to their ability to act as moral beings and to participate in civil society. If and when it becomes technologically possible to grow children outside of a woman's body, ${ }^{258}$ the moral and constitutional issues we confront in relation to abortion will be categorically different than they are today. But for today, reproductive freedom is, inescapably, the core issue of women's equality and liberty.

\section{B. Application of the Proposed Standard to Other Laws Dealing with Sex-Specific Physical Characteristics}

The standard proposed here asks that we first distinguish between

the means to control reproductive capacity.

To give men the unreviewable power to sentence women to childbearing and childraising against their will is to delegate a sweeping and unaccountable authority over the lives of others. Any such allocation of roles would operate to the serious detriment of women as a class, given the multitude of ways in which unwanted pregnancy and unwanted children burden the participation of women as equals in society. Even a woman who is not pregnant would inevitably be affected by her knowledge of the power relations thereby created.

Tribe, supra note 249 , at $40-41$ (footnotes omitted).

Professor Kenneth Karst observes, "Only a lawyer (a male lawyer) could regard laws [regulating pregnancy, abortion, and contraception] as sex-neutral." Karst, supra note 222 , at 57 n.320.

234 Fundamentalist Protestant and Mormon opposition to abortion is based on belief in the biblically ordained status of women as subordinate to men. The patriarchal family is the model for all human relations, with God in command of the universe and men in command of the home. The wife must submit to the husband's leadership "and help him fulfill God's will for his life." Children must obey teachers, workers obey employers and citizens obey civil authority. "The lines then descent and converge upon the 'total family'-father first, then mother, then children. The organization chart is entitled 'God's chain of command." "FitzGerald, A Reporter At Large: A Disciplined Charging Army, New YoRker, May 18, 1981, at 74.

26s For a discussion of this technology, see supra notes $32 \& 245$. 
laws governing reproductive biology and laws that classify explicitly on the basis of sex and then recognize that laws governing reproductive biology raise serious concerns about sex equality and therefore must be justified by compelling state interests if they perpetuate the inequality of women. This standard will now be applied to a number of state policies that raise concerns about sex-based equality but that would probably be subject only to minimum scrutiny under the current, flawed equality doctrine. Consider the following:

1. To protect the health of pregnant women, state policy requires that they quit public employment in the sixth month of pregnancy. ${ }^{256}$

2. To protect the health of future children, state policy prohibits the employment of women of childbearing age in positions in which they may be exposed to substances that may be damaging to fetuses or future reproductive capacity. ${ }^{257}$

3. To limit the cost of employee disability insurance, benefits for disabilities arising from normal pregnancy are excluded. ${ }^{258}$

4. a) Recognizing the physical burdens that pregnancy imposes upon women, a state requires that employers allow pregnant workers reasonable absences from work for medical disabilities associated with pregnancy. ${ }^{258}$

b) Recognizing the special nutritional needs of pregnant women, the government provides supplemental food benefits for them. ${ }^{280}$

5. a) The state allows up to six months of maternity leave at half pay to women employees who are nursing infants.

b) The state allows all mothers, but not fathers, six months of child care leave at half pay, whether or not they are nursing.

6. In an effort to provide a social counterbalance to men's relatively minor role in reproduction and to encourage male involvement with young children, the state requires that a pregnant woman inform the man who impregnated her of the fact of pregnancy, unless she has reasonable grounds to believe that he would physically abuse her if he were informed.

2se See Cleveland Bd. of Educ. v. LaFleur, 414 U.S. 632 (1974). The Supreme Court's decision in LaFleur is discussed supra notes 103-05 and accompanying text.

${ }^{257}$ See generally Williams, Firing the Woman to Protect the Fetus: The Reconciliation of Fetal Protection with Employment Opportunity Goals under Title VII, 69 GEO. L.J. 641, 641-43 (1981).

${ }^{258}$ See Geduldig v. Aiello, 417 U.S. 482 (1974). The Supreme Court's decision in Geduldig is discussed supra notes $106-15$ and accompanying text.

${ }^{259}$ See Miller-Wohl Co. v. Commissioner of Labor and Indus., 515 F. Supp. 1264 (D. Mont. 1981) (upholding similar rule against equal protection challenge).

260 This is the WIC program described supra note 185. 
The first three examples describe laws that govern reproductive biology and therefore are subject to scrutiny under the proposed standard. A requirement that women quit work once they reach the sixth month of pregnancy reflects a stereotype of incompetence that is most often inaccurate. This policy is similar to the rule that the Supreme Court struck down in Cleveland Board of Education v. LaFleur ${ }^{261}$ as an "irrebuttable presumption."262 The sex-equality analysis at the core of my proposed standard is, however, a stronger way of assessing the policy than the analysis that has grown out of the Court's limited understanding of sex equality. The law barring women from jobs that involve exposure to teratagenic chemicals stereotypes women as childbearers, a stereotype that is inaccurate in relation to the many women who cannot or intentionally do not bear children. The third example, which excludes payments for pregnancy-related disabilities from insurance plans, reflects a stereotype of women as temporary visitors to wage labor whose contributions are insignificant and for whom job continuity is unimportant.

Having determined that each of the three policies has a substantial impact upon perpetuating sex-role stereotypes, each policy must be strictly scrutinized. It is clear that alternative, sex-neutral means are available to promote any of the legitimate goals that the state might hope to serve by enforcing these rules. For example, a concern that workers be physically fit can be served by a more individualized approach that encompasses non-pregnancy-related disabilities and that recognizes that many pregnant women are not disabled. Professor Wendy Williams has outlined in comprehensive detail some of the ways in which a state might limit the destructive effects of teratagenic chemicals while minimizing the damage to women's equality as wage workers. $^{283}$ There are many ways to limit the costs of employee disability

261414 U.S. 632 (1974).

282 Id. at 644.

203 See Williams, supra note 257. Williams discusses the tension between two strong societal interests-equal employment opportunities for women and protection of the future children of workers. Some employers currently protect future children by barring all women between the ages of 18 and 50 from certain jobs deemed hazardous unless the women can prove infertility. Since approximately two-thirds of all women workers fall within this category, the burden is quite high in light of the goals of Title VII to eliminate sex discrimination in employment including discrimination related to pregnancy. Also teratogenic substances most likely have mutagenic effects as well, which can be transmitted through sperm. Therefore merely excluding women from exposure may not be the most appropriate method of protecting fetal health. There may actually be discriminatory motives in these employment policies, especially since "[w]omen have been excluded more often from traditionally male-intensive jobs than [from] female-intensive jobs, even when exposures are similar." Id. at 649 (footnote omitted). 
programs without imposing the burdens exclusively on pregnant women.

The fourth example postulates a pair of laws, one requiring employers to allow pregnant workers reasonable absences from work without losing their jobs and the other providing special nutritional benefits to pregnant women. This type of law presents a closer case. When Montana adopted a law requiring that leave from work be allowed for pregnant women, feminists were divided in their views about whether it should be regarded as sex discriminatory. ${ }^{264}$ For more than a decade, the federal government has administered the Supplemental Food Program for Women, Infants, and Children (WIC), a program that provides nutritional benefits to pregnant women. ${ }^{26 s}$

These two laws plainly govern reproductive biology. Whether they have a substantial impact upon perpetuating inequality is less clear. Such laws do not perpetuate cultural sex role stereotypes because they are tied precisely to the biological fact of pregnancy. A law providing help to pregnant women does not oppress women in a obvious way. The law requiring reasonable leave for pregnant women is dangerous, however, because the employer may decide to avoid the burden of providing the required protection by simply not hiring women who might become pregnant. Whether that danger is sufficiently real to enable one to conclude that the protective law oppresses women should, I believe, be treated as a question of fact and judgment, not as a matter of ideological preconception. It is possible that evidence would substantiate the fear that a mandatory leave rule would limit women's job opportunities.

Many issues are relevant to the assessment whether such a law oppresses women or whether it is supported by compelling state pur-

Williams rejects two possible options for resolving the tension: allowing employers a free hand to express their concern over fetal well-being in any way they choose or giving the woman employee an absolute right to choose the risks to which she will expose her fetus. Instead, an appropriate balance of both interests must be reached. To begin with, the policy must "[look] to the broad spectrum of ways in which exposures of men and women can affect fetal health." Id. at 665. The assumption that the woman worker is the proper target for exclusion must be rejected. "Rather, the presumption should be that all workers may be subject to the reproductive hazards that could result in birth defects and that the exclusion solely of women workers is unwarranted unless or until the contrary is shown." Id. Any valid policy, therefore, must be gender neutral. If after appropriate investigation, a substance is found only to affect the fetus through exposure of the mother, then only women need be excluded. The burden however would be on the employer to show that female exposure is the only risk, that no less discriminatory alternative was available, and that the restriction was narrowly drawn. Id. at 667 .

204 See, e.g., Williams, supra note 199, at 194-200 (describing the Montana law and the feminist reactions to it).

${ }^{203} 42$ U.S.G. § 701 (Supp. V 1981); see supra note 185. 
poses. For example, can we foresee concrete ways in which the measure providing help to pregnant women can be used to hurt them? This inquiry distinguishes the WIC program from laws providing mandatory leaves for pregnant women, for it is difficult to see how the WIC program hurts women. Is the benefit provided so trivial that its primary function is to reinforce stereotypical ideas about men and women? ${ }^{268}$ At the other extreme, is the protection mandated for pregnant women so substantial that it is likely that those required to provide it would avoid dealing with women in order to escape it? For example, a law demanding that employers provide pregnant workers four months leave with pay would very likely have an adverse effect on women's employment opportunities. It is, however, difficult to imagine facts that would support a conclusion that the law providing nutritional benefits to pregnant women enforces cultural stereotypes or is oppressive. In either case, if a court concluded that the law in fact had a substantial impact in perpetuating inequality, the law would have to be struck down. The state could employ alternative, sex-neutral means of achieving its objective of protecting against dismissal for health-related absences or of ensuring a nutritionally adequate diet.

To understand fully the difficult issue posed by these two laws, it is useful to examine the feminist opposition to them. One objection to such laws, with which I fully agree, is that they are politically divisive. "Creating special privileges of the Montana type [example 4(a)] has, as one consequence, the effect of shifting attention away from the ... state's failure to provide important protections to all workers and focusing it upon the unfairness of protecting one class of worker and not others."267 In developing a political strategy for the less affluent majority, it is vitally important to frame issues in ways that unite rather than divide people. ${ }^{268}$ But the political reality is that it is often easier to persuade a legislature to help or protect a particular group that is smaller than all who might need the help or protection.

A second feminist objection to laws providing special protections and benefits to pregnant women rests on a view of equality that says that "[c]onceptualizing pregnancy as a special case permits unfavorable

${ }^{266}$ Kahn v. Shevin, 416 U.S. 351 (1974), though not involving a law governing reproductive biology, illustrates the problem. There, the Court upheld a Florida law affording women a maximum tax benefit of $\$ 15$ per year to compensate them for discrimination in the job market. Taub observes that this "crude brand of compensation they purport to offer women is both inadequate and a distraction from the real problems women face." Taub, supra note 197, at 1692.

267 Williams, supra note 199, at 196.

${ }^{268}$ See, e.g., Sparer, Gordian Knots: The Situation of Health Care Advocacy for the Poor Today, 15 Glearinghouse Rev. 1 (1981). 
as well as favorable treatment of pregnancy."269 This argument has tremendous power, given our present constitutional equality doctrine that persistently confuses reproductive biology with cultural patterns and that wholly denies the applicability of equality norms to laws governing reproductive biology. But this is not necessary as a matter of nature or logic. Rather we could, as I have urged here, develop a concept of equality that distinguishes between reproductive biological difference and cultural generalizations and that prohibits regulation of reproductive biology whenever it oppresses women or reinforces cultural sex-role stereotypes.

A final feminists' objection to such laws rests on an understanding of our history in which biological difference has been used to justify a separate role and world for women. Less than a century ago "doctors and scientists were generally of the view that a woman's intellect, her capacity for education, for reasoning, for public undertakings, was biologically limited."270 This history demands profound skepticism of rules based on the fact that men and women are biologically different, but does it require that we reject any recognition of sex-based biological difference? Acknowledging the reality and importance of the reproductive biological difference does not necessarily set us on a slippery slope on which the state is allowed to exaggerate the costs of difference. Recognizing that men and women are different in relation to reproductive biology does not necessarily mean that the law can assume that we are different in relation to capacity to think, to lead, or to nurture. It is likely that courts would be less inclined to confuse biology with the social consequences of biology if a finding that a law was premised on biological differences between men and women were only the beginning and not the end of the equality inquiry. Confronting the myth and reality of biological differences may enable us to create a stronger equality concept in relation both to laws premised on cultural stereotypes and to laws that regulate reproductive biology.

The fifth example given above presents problems in relation to maternity and paternity leaves to care for young children. The policy providing child care leave to nursing mothers is one governing reproductive biology. Does the policy have a substantial impact in perpetuating inequality? It seems that it does. Either parent, or a stranger, is biologically capable of caring for a child. Limiting the childrearing to nursing women reinforces the cultural expectation that "the paramount destiny and mission of woman are to fulfill the noble and benign offices

260 Williams, supra note 199, at 196.

270 Id. at 199 (and sources cited therein). See also R. Rosenberg, BEYOND SEPARAte Spheres: Intellectual RoOts of Modern Feminism (1982). 
of wife and mother." ${ }^{\text {271 }}$ Such a policy would have to be struck down because it could not withstand strict scrutiny; the state's interest in promoting the physical or psychic benefits of nursing is not sufficiently substantial to justify the burden upon men and women who would choose to take child care leave but who cannot nurse. Also, the oppressive effect upon women who would prefer not to nurse but are compelled to do so in order to qualify for the leave is not justified by the state's interest.

The second law presented in example 5 allows child care leave for mothers but not for fathers. This is not a law that governs reproductive biology but is instead a simple sex-based classification. A law based on what the government perceives to be the ability and willingness of certain citizens to care for children is not a law governing reproductive biology. A general maternal child care leave policy would be prohibited under the ERA and would need to be justified under the Craig standard as having a close relation to important government interests. The general maternal preference law would not be justifiable even under the more relaxed requirements of the Craig standard if challenged by a father who was able and eager to care for his child.

The final case, a statute requiring that a pregnant woman notify the man who impregnated her of the fact of the pregnancy, can be seen as a law governing reproductive biology. It addresses a problem of vital social importance-the law lends practical and symbolic force to the idea that men, as well as women, are responsible for the children they create and attempts to mitigate the effects of men's relatively minor role in relation to reproduction.

The hypothetical policy is far more sensitive to equality concerns than consent and notification requirements that are triggered by a woman's decision to have an abortion-requirements that have in the past been held unconstitutional. ${ }^{272}$ The hypothetical law directs the

271 Bradwell v. Illinois, 83 U.S. (16 Wall.) 130, 141 (1873).

272 Planned Parenthood v. Danforth, 428 U.S. 52, 67-72 (1976), held that the state may not give a husband the right to veto a woman's decision to abort. In Scheinberg v. Smith, 482 F. Supp. 529 (S.D. Fla. 1979), rev'd, 659 F.2d 476 (5th Cir. 1981), the district court struck down a state law prohibiting physicians from performing abortions for married women unless the husband was given prior notice. The Fifth Circuit reversed, holding that even though the requirement burdened the woman's access to abortion, it was supported by a compelling state interest in "maintaining and promoting the marital relationship; and protecting a husband's interest in the procreative potential of the marriage." 659 F.2d at 483.

Having children is a major purpose of the institution of marriage. . . . If proper abortion procedures have the potential to affect adversely a woman's future procreative ability, the state may require notice to the husband of the abortion, and hence of the possible impact on the marriage's child-bearing capacity, whether or not he is the father of the fetus. 
woman to provide the information, rather than imposing the requirement on a physician. ${ }^{273}$ It excuses notification when she has reason to fear violence. It gives the man only information, not a formal right of veto. Most significantly, it is not directed solely to women who seek abortions. A requirement that men be notified only when the pregnant woman seeks an abortion powerfully reinforces the cultural stereotype that motherhood is women's destiny. A man's concrete emotional, moral, and financial interest is vastly greater when a pregnancy he has helped to create is carried to term than when it ends in abortion. Abortion-only consent and notification policies express disapprobation for abortion, regard the woman as a "mother-machine," and are indefensible as a neutral means of increasing male involvement with reproductive decision-making.

But even this more sensitive notification requirement is oppressive to women. The biological reality that "it is the woman who physically bears the child and who is the more directly and immediately affected by the pregnancy"274 must preclude the state from giving the man power over her decision whether to abort or to carry the pregnancy to term. A requirement of notification, as opposed to a formal veto, has effect only in those situations where the woman determines that communication with the man is unwise. ${ }^{275}$

A man's interest in a pregnancy he has helped to create is undeniably great. But a man's interest in having children does not justify imposing the burden of pregnancy and motherhood on a particular woman. Even if that woman is his wife, the burdens of pregnancy, which the woman inescapably bears, are too great to allow the man to

Id. at 486-87. On remand, the district court found that, as a matter of fact, abortion does not have any adverse effect on woman's procreational potential. See 550 F. Supp. 1112, 1116-23 (S.D. Fla. 1982).

273 The abortion-only consent and notification requirements have been directed to physicians. They reflect contempt for the woman as a law abiding citizen and impose burdens on physicians that exacerbate the shortage, and in many areas total unavailability, of doctors willing to perform abortions. In 1980, 78\% of all U.S. counties had no identified providers of abortion services. Henshaw, Forrest, Sullivan \& Tietze, Abortion Services in the United States, 1979 and 1980, 14 Fam. Plan. Persp. 5 (1982).

274428 U.S. at 71.

228 Apart from the risk of physical violence, which the hypothetical statute addresses, a woman may have a variety of legitimate reasons for deciding that it is unwise to communicate information about pregnancy to the father. For example, the man may be physically or mentally ill and incapable of coping. Or the woman may decide that because of limited financial resources and obligations to other children she should have an abortion, which the man would reject for reasons of religious principle. The woman in this situation might reasonably believe that her choice to abort would damage her valued relationship with the man. Or the woman might believe that the man would subject her to coercive pressures other than physical violence. The possibilities are endless. 
impose them upon her. A man's interest in terminating a pregnancy he has helped to create may also be very great. He may be emotionally and financially incapable of assuming responsibility for a child. Perhaps society should allow biological parents greater freedom to reject the rights and responsibilities of parenthood. ${ }^{276}$ There is a strong public interest in encouraging fathers to be more involved in the nurturing and care of their children. The notification requirement may promote this interest. While this case is, for me, a difficult one, I do not believe that even this sensitive notification policy could survive the strict scrutiny that is appropriate to an analysis of laws that oppress women through the regulation of reproductive biology. We do not now require that mothers notify fathers at the point of birth and a multitude of public policies limit, rather than enhance, the father's participation in the nurturing of children.

But parents' responsibilities to their children are not a function of reproductive biology. Such responsibilities can and should be defined in sex-neutral terms.

\section{The Future of Sex-Based Equality Under the FOURTEENTH AMENDMENT AND THE ERA}

The Supreme Court's doctrine of sex-based equality under the fourteenth amendment is exceedingly unstable. This instability is manifest in the sharp divisions in analysis and result in cases such as Parham v. Hughes, ${ }^{277}$ Caban v. Mohammed, ${ }^{278}$ Lehr v. Robertson, ${ }^{279}$ and Michael M. v. Superior Court. ${ }^{280}$ The core principles of the Court's equality doctrine-the requirement that men and women be treated as individuals rather than stereotypes and the recognition that laws based on stereotypical assumptions are self-fulfilling as well as inaccurate in particular cases-are inconsistent with the approach that various members of the Court have taken in these cases. An unstable present necessarily implies an uncertain future.

The fourteenth amendment guarantees equal treatment under the law and recognition of the injustice of denying men and women opportunities solely on the basis of sex is broad and deep. It would be possible to achieve greater strength and stability in sexual equality doctrine

276 As a practical matter, parents of healthy young children have no difficulty forfeiting parental rights and responsibilities and shifting those responsibilities to adoptive parents.

277441 U.S. 347 (1979).

278441 U.S. $380(1979)$.

278103 S. Ct. 2985 (1983).

280450 U.S. 464 (1981). For a discussion of these cases, see supra notes 126-82. 
through the approach advocated here, which focuses directly on the reality and myth of biological differences. The Gourt could draw a sharp distinction between laws creating sex-based classifications and laws regulating sex-specific physical characteristics and still recognize that laws regulating sex-specific physical characteristics implicate the core concerns of sex-based equality.

For the most part the argument advanced here builds upon equality and privacy doctrine. Courts are skilled at the manipulation of doctrine. When doctrine develops quickly, in response to large changes in consciousness, modification in the light of experience and insight seems particularly appropriate. The analysis in cases such as Michael M., Parham, and Caban is not so compelling, nor the results so clear, that their approach need determine the way in which the Court analyzes future cases raising issues different than those resolved there. Other cases, notably Geduldig, are not so easily confined through the manipulation of doctrine. The Court should simply overrule Geduldig, recognizing it as the false step that Congress, nearly every commentator, and the Court itself have regarded it. ${ }^{281}$

The Equal Rights Amendment has been defeated, but it is certain to rise again. What is not so certain is whether we will continue to regard laws regulating reproductive biology as tangential to the constitutional guarantee of sex-based equality. The direction in which the Court will move under the fourteenth amendment and the vision of sexbased equality reflected in the next ERA depend in large part upon the vision of equality adopted by those who shape claims of sex-based equality and reproductive freedom under existing constitutional guarantees and those who fight for the new ERA.

The ideas developed here are simply one woman's thoughts about the meaning of sex equality, under either the fourteenth amendment or the ERA. Although I support the Equal Rights Amendment, its major congressional proponents and the leaders of the struggle to enact it have

281 See supra notes 106-10. Under the equality analysis presented here, policies excluding payment for abortion for the otherwise comprehensive Medicaid program are laws governing reproductive biology that plainly oppress women and are not supported by important state interests. Whether the Supreme Court's decisions in Harris v. McRae, 448 U.S. 297 (1980), and Maher v. Roe, 432 U.S. 464 (1977), are therefore wrong also depends upon whether we are persuaded by the Court's assertion that the government doesn't do anything when it withholds public funds. See 448 U.S. at 31618. (denying funding for abortion leaves the poor woman in the same situation she would be in "if Congress had chosen to subsidize no health care costs at all"). For a powerful critique of this assertion see Perry, Why the Supreme Court Was Plainly Wrong in the Hyde Amendment Case: A Brief Comment on Harris v. McRae, 32 StAN. L. REV. 1113 (1980). 
expressed a different vision of sex-based equality. ${ }^{282}$ Strong reasons, both political and conceptual, support separation of doctrines of sex equality and reproductive freedom. The political reality is that extreme conservative religious and political groups have made opposition to abortion an organizing issue-a sine qua non political test. ${ }^{283}$ Although there is wide political support for equal pay for equal work and the claims of individual aspirational women seeking access to traditional male power, women's claims for control of their bodies present a more profound challenge to prevailing structures of male dominance, and are less widely accepted. Conceptual support for the separation of sexbased equality and reproductive freedom rests on skepticism whether courts are able to implement, with good faith and good sense, a concept of sex equality that recognizes the reality of biological difference. ${ }^{284}$ Further, privacy doctrine is richly developed in relation to reproductive freedom, and a shift to sex equality analysis in these cases seems, to many, unlikely. ${ }^{285}$

${ }^{282}$ See supra notes $72,114 \& 115$; U. S. CoMm'N on Givil Rights, The EQUal Rights AMENDMENT: GuaRANTEEING EQUAL RightS FOR WOMEN UNDER THE CONSTITUTION (1981) (explaining and supporting the ERA without mentioning abortion or pregnancy). In the contemporary ERA debate, Sen. DeConcini (D. Ariz.), for example, states,

I strongly support and am a co-sponsor of the Equal Rights Amendment. I also strongly support pro-life legislation, and have done so throughout my career in the Senate. In my mind, there is no connection whatsoever between the ERA and abortion. I further believe that no such connection could or should be made here.

Even if the Supreme Court, in its wisdom, reverses itself on the use of the privacy doctrine to permit abortion, I do not believe the ERA would or should serve as a substitute rationale.

I, and I suspect a number of other colleagues who are also in the proERA, pro-life category - and there are close to a dozen of us in the Senate-would have great difficulty supporting the ERA if we felt that it could be interpreted by a future court to give assistance in any degree to forces that have a pro-choice attitude towards life or death of the unborn.

The Impact of the Equal Rights Amendment upon Abortion Rights: Hearings before the Subcomm. on the Constitution of the Senate Comm. on the Judiciary, 98th Cong., 2d Sess. 65 (1984).

${ }^{283}$ See F. JAFFeE, B. Lindheim \& P. LEe, supra note 116, at 165-79.

284 See, e.g., Taub, supra note 197. Taub argues that even a government financed program targeting special benefits to pregnant women is unconstitutional because "the effect of the scheme would be to reinforce the notion for women and men that childbearing is woman's primary function and that pregnancy is an illness meriting special protection." Id. at 1693 . Taub argues against an equality standard that would incorporate recognition of unique sex-based characteristics, asking, "How, then, can we go to a male-dominated court system and ask for a fair accommodation of women's unique requirements?" Id. at 1691 .

${ }^{288}$ Professor Ann Freedman, co-author of the ERA Article, see supra note 4, and spokesperson for a coalition of groups supporting the ERA, explains,

I believe the issue of abortion is not germane to Congressional consid- 
Nonetheless, as this Article has attempted to demonstrate, a strong concept of sex-based equality will require that we come to grips with the reality of sex-based biological differences, either through the approach proposed here or in some other way. A political struggle that embraces recognition that men and women are both limited by biology and able to transcend it may be stronger than one that ignores the core reality of sex difference in relation to reproductive biology.

Are we locked into the road we have taken? Are the two lines of constitutional doctrine-reproductive freedom and sex-based equality-which began as a unified whole to preserve male dominance and diverged in the early 1970's, now on fixed projections that move ineluctably further apart? I think not. The law is a social creation that produced the legal structure that made biology destiny and enforced the subjugation of women. In the 1970's we began the divergent movements to create a different social construct of sex equality and reproductive freedom. We can, if we choose, move toward a more unified under-

eration of the ERA, which should be promptly adopted on its own merits and should not be used as an occasion for a debate about the merits of the Supreme Court's decisions concerning the constitutional right to privacy.

[T] The ERA does not have a practical effect, in my opinion, on constitutional decisionmaking about abortion.

[This is] because of the Supreme Court's well demonstrated commitment to an alternative form of constitutional analysis, the constitutional right to privacy.

There is no reason to believe that the Supreme Court will abandon privacy analysis and adopt a new form of constitutional analysis based on the ERA. On the contrary, there are powerful reasons to believe that the Court will continue to adhere to privacy analysis on the issue of abortion.

Thus, if the Supreme Court in the future wished to invalidate abortion funding restrictions, it is my opinion that they would do so under the constitutional right to privacy and not in reliance on the ERA.

[R]estrictions on abortion choice are subject to strict constitutional scrutiny under the constitutional right to privacy. Under the ERA, pregnancy-related laws would be subject to strict scrutiny. This is the same standard.

Were the Court to consider changing its mode of analysis from privacy to ERA and review abortion laws as pregnancy regulations, the standard of review would thus be the same as that already required under the constitutional right to privacy. Because both doctrines mandate the same level of scrutiny, there is no reason to expect the Court to switch its form of analysis or to reach different results if it were to do so.

The Court adhered to its holding concerning the use of strict scrutiny to review governmental restrictions on abortion choice in [Harris v. Mc$R a e]$, while at the same time upholding the government's power to structure medical assistance funding to favor childbirth over abortion.

The Impact of the Equal Rights Amendment upon Abortion Rights: Hearings before the Subcomm. on the Constitution of the Senate Comm. on the Judiciary, 98th Cong., 2d Sess. 6-8 (1984) (testimony of Ann Freedman). 
standing of the ways in which the law perpetuates sex-based restraints on human equality and liberty. 